ISIS RYAL CROSATO

\title{
AVALIAÇÃO DAS CARACTERÍSTICAS DOS SERVIÇOS ODONTOLÓGICOS EXISTENTES EM EMPRESAS DO ESTADO DE SÃO PAULO
}




\title{
Isis Ryal Crosato
}

\section{Avaliação das características dos serviços odontológicos existentes em empresas do estado de São Paulo}

\author{
Dissertação apresentada à Faculdade de Odontologia \\ da Universidade de São Paulo, para obter o título de \\ Mestre, pelo Programa de Pós-Graduação em \\ Ciências Odontológicas. \\ Área de Concentração: Odontologia Social \\ Orientador: Prof. Dr. Moacyr da Silva
}

São Paulo 


\section{FOLHA DE APROVAÇÃO}

Crosato IR. Avaliação das características dos serviços odontológicos existentes e m empresas do estado de São Paulo [Dissertação de Mestrado]. São Paulo: Faculdade de Odontologia da USP; 2006.

São Paulo, __ _ _ _ 2006

\section{Banca Examinadora}

1) $\operatorname{Prof}(a) . \operatorname{Dr}(a)$

Titulação:

Julgamento:

Assinatura:

2) $\operatorname{Prof}(a) . \operatorname{Dr}(a)$

Titulação:

Julgamento:

Assinatura:

3) $\operatorname{Prof}(a) . \operatorname{Dr}(a)$

Titulação:

Julgamento:

Assinatura: 
Aos meus pais, Carlos Crosato Neto e Elisabeth Ryal Crosato, pelo exemplo de dignidade, pelos esforços envidados e, acima de tudo... pelo amor incondicional e palpável que ilumina cada passo da minha trajetória.

A vida me é tão mais doce porque vocês estão por perto... 


\section{AGRADECIMENTOS}

Ao Prof. Dr. Moacyr da Silva, que com tranqüilidade e sapiência me orientou, me acolheu e me ajudou a conhecer "o caminho das pedras".

Ao Prof. Dr. Edgard Crosato, co-orientador deste trabalho, que me ensinou a ter paciência quando tudo se me afigurava perdido, quando eu temia e tremia de ansiedade. A sabedoria caminha de mãos dadas com a simplicidade.

À Profa. Dra. Maria Ercilia de Araujo, chefe do Departamento de Odontologia Social quando ingressei no Programa de Pós-Graduação e novamente chefe agora que estou saindo... Sorrisos iluminados, afabilidade e simpatia, sem deixar de lado a seriedade profissional. Marca do ODS ou marca sua?

Aos professores do Departamento de Odontologia Social da Faculdade de Odontologia da Universidade de São Paulo, pelo desprendimento, pela disponibilidade, pelos ensinamentos...

Ao Luís Eugênio Nigro Mazzilli, pela colaboração inconteste nos momentos difíceis desta trajetória (textos, referências, opiniões).

A Ana Paula Fassina e Jair de Souza Moreira Junior, amigos e companheiros, que tornaram menos árduo este caminho...

Aos colegas do SESC, pela alegria constante, que transforma nossas jornadas de trabalho em momentos prazerosos, e pelo incentivo infindável.

À Luciana Liuzzi, ao Eleno Gonçalves Junior e ao Ricardo Baldacin Salgado, pelo auxílio na elaboração deste trabalho, pela amizade e dedicação.

Às minhas amigas queridas, companheiras de todas as horas...

Aos colegas do Programa de Pós-Graduação em Ciências Odontológicas (Odontologia Social), pela convivência amigável e pela troca de informações.

Às 'meninas' da Secretaria do Departamento de Odontologia Social, Andréia, Laura e Sônia, pelas informações precisas, pela convivência agradável, pelos inúmeros cafés que tomamos juntas... A gentileza, a simpatia, a amizade e a inteligência sempre são bem-vindas. Muito obrigada! 
Crosato IR. Avaliação das características dos serviços odontológicos existentes em empresas do estado de São Paulo [Dissertação de Mestrado]. São Paulo: Faculdade de Odontologia da USP; 2006.

\section{RESUMO}

O presente estudo propô-se a levantar informações sobre a saúde bucal dos trabalhadores, e a verificar a presença - e avaliar como tais serviços são geridos - ou a ausência de serviços odontológicos em algumas empresas do estado de São Paulo no ano de 2004, e elaborar um programa de promoção de saúde bucal dirigido aos funcionários de empresas. A fundamentação teórica necessária ao objetivo proposto apoiou-se na revisão da literatura especificamente voltada à atividade laboral - medicina do trabalho, engenharia do trabalho, direito do trabalho e odontologia do trabalho. Para melhor ilustrar os temas propostos, optou-se por adotar metodologia que permitisse obter uma base de dados quantitativos e qualitativos em profundidade. Os resultados indicaram que apenas $20 \%$ dos cirurgiões-dentistas participam dos SESMTs; da mesma forma, $86,67 \%$ desses profissionais não participam das CIPAs, embora 6,67\% das empresas entendam que é necessário que o CD esteja a par dos assuntos abordados e discutidos em tais reuniões. Das empresas entrevistadas, $80 \%$ oferecem algum tipo de serviço odontológico (consultório particular dentro da empresa, atendimento terceirizado e autogestão, entre outros) e, dentre estas, $25 \%$ já implantaram os Serviços de Odontologia do Trabalho para melhor gerenciar a saúde dos trabalhadores. Quanto à realização de exames odontológicos ocupacionais, 53,33\% das empresas já mantêm esse protocolo em funcionamento, com predominância de realização de 
exames admissionais e periódicos - cuja obrigatoriedade legal não está prevista na legislação brasileira. Em relação aos afastamentos por intercorrências odontológicas, $60 \%$ dos entrevistados relataram que eles existem, e na maioria das vezes implicam de um a três dias de ausência. Em contrapartida, o restante não possui documentação de tais dados. Observourse, ao final do estudo, que $60 \%$ das empresas já abordaram questões relacionadas à orientações e aos cuidados com a saúde bucal de seus trabalhadores em palestras e campanhas educativas. Ao final deste estudo foi elaborado um Programa de Promoção de Saúde Bucal, com o intuito de implementar os cuidados relativos à saúde dos trabalhadores.

Palavras-chave: saúde ocupacional - saúde bucal - programa de saúde bucal do trabalhador 
Crosato IR. Evaluation of dentistry services characteristics in companies of São Paulo State [Dissertação de Mestrado]. São Paulo: Faculdade de Odontologia da USP; 2006.

\section{ABSTRACT}

This study described herein are comprised of a research on the main companies of the State of São Paulo, in regards to the existence and methodology of their worker's oral health. The main purpose of this study is to propose an efficient Program of Dentistry Plan addressed to those companies that aware of profitable benefits resulted from a successful worker's oral health. Despite the labor dentistry be a relative new matter of concern, this research grounded its basis in a complete and intense analyze of different areas of science, such as Industrial Medicine, Labor Engineering and Law, in a way to provide a not only a wide broad data base of information, but also a qualified understanding of its content. In general terms, the results indicated that only $20 \%$ of the dentist surgeons participate of SESMT, that $86.67 \%$ of them is not member of the CIPA committee, as well as that only $6.67 \%$ believe that labor dentistry issue should be included in the agenda of conferences. In the other hand, the research demonstrated that $80 \%$ of the companies offer some kind of dentistry services to its employees (internal dentistry centers, outsourced consults etc.) and at least $25 \%$ of those companies have already implemented the Labor Dentistry Services to improve the general health condition of its employees. In regards to preventive measures, $53.33 \%$ of the companies perform admission or periodical on-the-job dentistry exams, even if still not required by federal applicable law. The company's concern on promoting educational seminars and campaigns is 
grounded in the fact that in $60 \%$ of the companies, from total of the employee's absence periods for diseases, 1 to 3 was related to dentistry problems and accordingly, this dissertation proposes the implementation of profitable plan of preventive Employees Dentistry Health.

Keywords: occupational health - oral health - worker's oral health program 


\section{LISTA DE ILUSTRAÇÕES}

Figura 5.1 Profissionais entrevistados (\%) nas 15 empresas investigadas 71

Quadro 5.1 Classificação adotada pelo cadastro do Centro das Indústrias do Estado de São Paulo em função do número de empregados de cada empresa .. 72

Figura 5.2 Porte (\%) das 15 empresas investigadas 72

Figura 5.3 Participação do CD no SESMT das empresas investigadas 81 


\section{LISTA DE ABREVIATURAS E DE SIGLAS}

\begin{tabular}{|c|c|}
\hline$A D A$ & American Dental Association \\
\hline ANEO & Assembléia Nacional de Especialidades Odontológicas \\
\hline art. & artigo(s) \\
\hline CFM & Conselho Federal de Medicina \\
\hline CFO & Conselho Federal de Odontologia \\
\hline CID & Código Internacional de Doenças \\
\hline CIESP & Centro das Indústrias do Estado de São Paulo \\
\hline CIPA & Comissão Interna de Prevenção de Acidentes \\
\hline CLT & Consolidação das Leis do Trabalho \\
\hline CNSB & Conferência Nacional de Saúde Bucal \\
\hline EPI & Equipamentos de Proteção Individual \\
\hline EUA & Estados Unidos da América \\
\hline INSS & Instituto Nacional do Seguro Social \\
\hline LRA & Laudo dos Riscos Ambientais \\
\hline MT & Ministério do Trabalho \\
\hline NR & Norma Regulamentadora \\
\hline OIT & Organização Internacional do Trabalho \\
\hline PMCSO & Programa de Controle Médico de Saúde Ocupacional \\
\hline PPRA & Programa de Prevenção de Riscos Ambientais \\
\hline RPS & Regulamento da Previdência Social \\
\hline
\end{tabular}


SESMT Serviços Especializados em Engenharia de Segurança e Medicina do Trabalho

SIPAT Semana Interna de Prevenção de Acidentes de Trabalho

SSST Secretaria de Segurança e Saúde do Trabalho

SUS Sistema Único de Saúde

WHO World Health Organization 


\section{SUMÁRIO}

\section{p.}

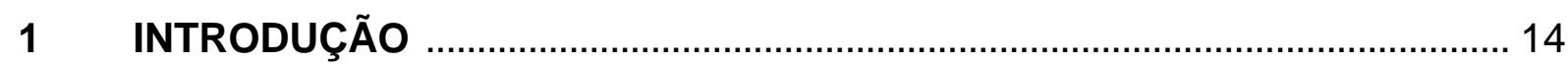

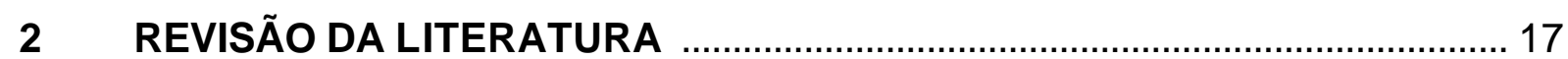

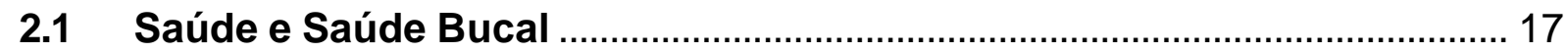

2.1.1 a importância da cavidade bucal .................................................................... 19

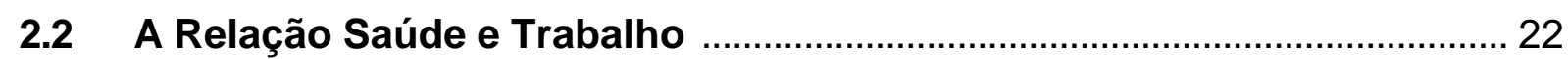

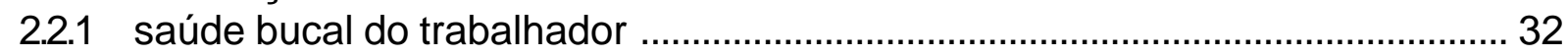

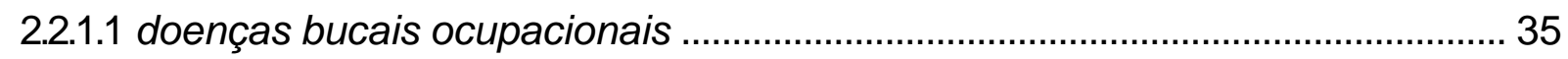

2.3 Relação Saúde e Trabalho na Legislação Brasileira .................................... 40

2.3.1 Consolidação das Leis do Trabalho (CLT) ......................................................... 41

2.3.2 Serviço Especializado em Engenharia de Segurança e Medicina do

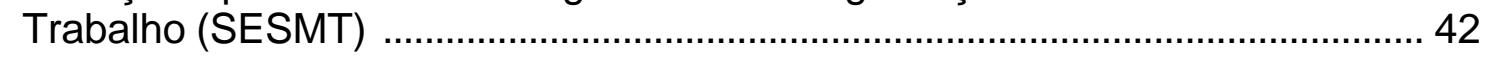

2.3.3 Comissão Interna de Prevenção de Acidentes (CIPA) ...................................... 44

2.3.4 Programa de Prevenção de Riscos Ambientais (PPRA) ................................... 44

2.3.5 Equipamentos de Proteção Individual .................................................................. 45

2.3.6 Programa de Controle Médico de Saúde Ocupacional (PCMSO) ..................... 46

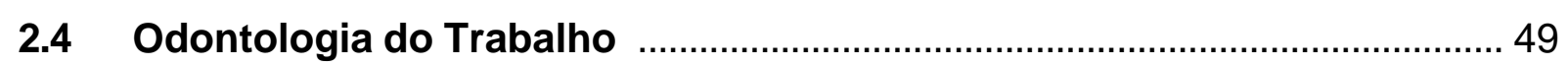

2.4.1 capacitação profissional para a odontologia do trabalho ..................................... 53

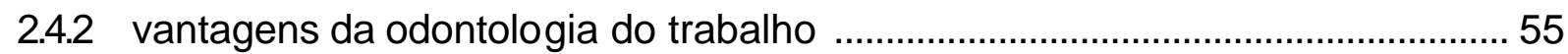

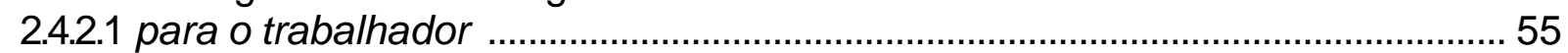

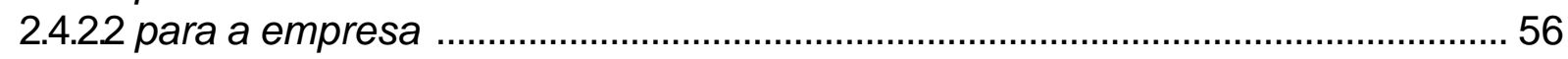

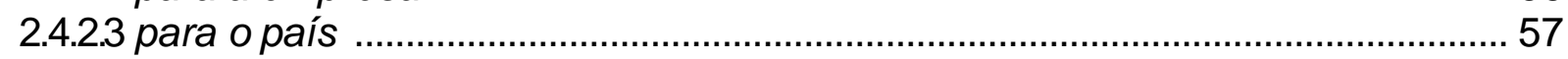

2.5 Programas de Promoção em Saúde ............................................................... 57

2.5.1 programas de promoção em saúde bucal ..................................................... 58

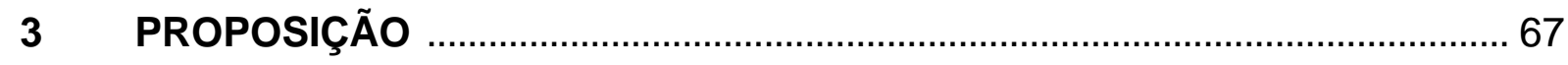

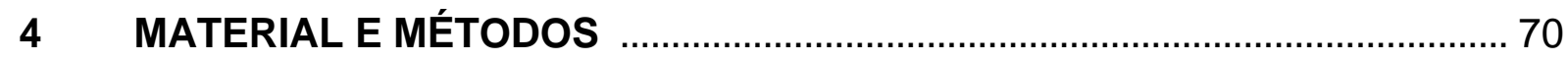

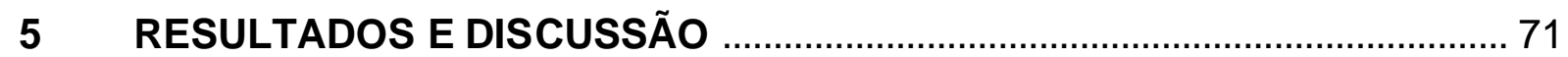

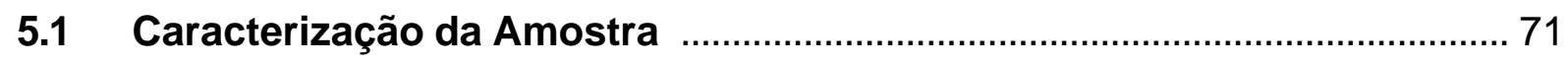

5.2 Participação do Cirurgião-Dentista no Serviço Especializado em Engenharia de Segurança e Medicina do Trabalho 80

5.3 Participação do Cirurgião-Dentista na Comissão Interna de Prevenção

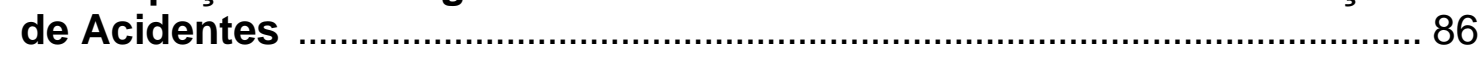

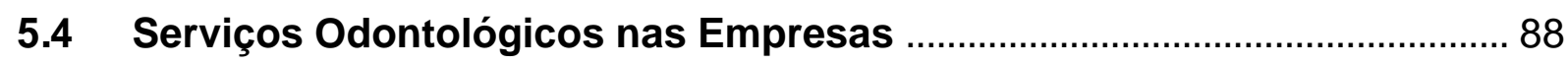

5.5 Exames Odontológicos Ocupacionais ….............................................. 102 
5.6 Absenteísmo decorrente de Problemas relacionados à Saúde Bucal . 120

5.7 Programas de Promoção da Saúde Bucal ................................................ 130

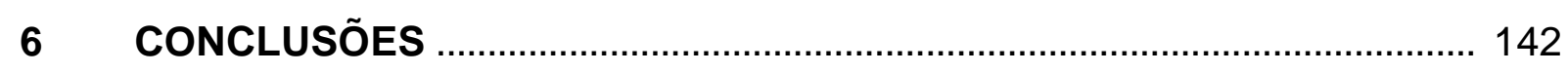

REFERÊNCIAS …........................................................................................... 144

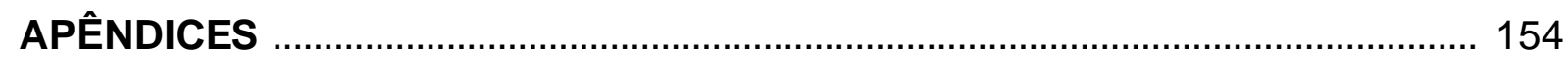

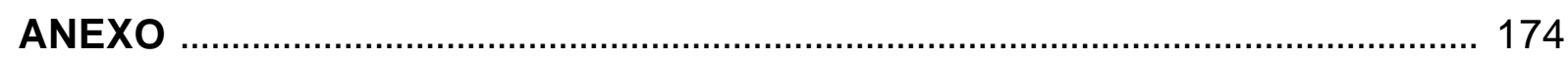




\section{INTRODUÇÃO}

A cavidade bucal tem vital importância na saúde do ser humano como um todo. É pela cavidade bucal que o indivíduo se comunica com o mundo exterior. Os sentidos, como o tato e o paladar, são transformados em emoções indescritíveis pelo ser humano em função da perspicaz sensibilidade desse sistema estomatognático. A alimentação é tida como base de sustentação dos homens, e sua digestão é iniciada na cavidade bucal com a função mastigatória dos músculos e dentes e a ação química das enzimas digestivas contidas na saliva.

A preocupação com a saúde dentro do processo de trabalho não é recente: já na história antiga há registros de que, para se protegerem da poeira das minas, escravos utilizavam bexigas de carneiro. O advento da Revolução Industrial delimitou uma nova fase no processo produtivo, e suscitou discussões e reivindicações que contemplaram desde as relações trabalhistas até os aspectos ligados à influência das condições da atividade desempenhada - como local e contato com agentes deletérios à integridade física do indivíduo, dentre outros sobre a saúde do trabalhador.

A valorização do homem no âmbito do trabalho tem tido muita ênfase nos últimos 100 anos, e tornourse um diferencial na cadeia produtiva. Programas para melhorar a qualidade de vida dos funcionários vêm sendo muito utilizados por empresários que acreditam que investir no trabalhador aumenta o lucro, pois implica maior produtividade para a empresa.

No Brasil, o primeiro instrumento legal de alguma relevância a intervir nas condições de trabalho foi a Lei de Acidentes de Trabalho, de 1919, fruto da pressão 
da classe trabalhadora da época, como informa Midorikawa (2000). No governo de Getúlio Vargas, foram criados o Ministério do Trabalho e a Inspetoria de Higiene e Segurança do Trabalho, que tinha a competência de coordenar, orientar, controlar e supervisionar as atividades relacionadas à segurança e à medicina do trabalho, e inclusive de fiscalizar o cumprimento dos preceitos legais e regulamentares em todo o território nacional (MIDORIKAWA, 2000). A partir daí, a preocupação com a saúde do trabalhador foi conquistando espaço e, em 1978, o Ministério do Trabalho, através da Norma Regulamentadora (NR) no 4 da Portaria 3214, estabeleceu a obrigatoriedade da implementação e manute nção de Serviços de Especializados em Engenharia de Segurança e Medicina do Trabalho (SESMT - BRASIL, 1998b). Com o objetivo de promover e preservar a saúde do trabalhador, a NR-7 dessa mesma Portaria obriga os empregadores a elaborar um Programa de Controle Médico de Saúde Ocupacional (PCMSO), e a NR-9 exige a elaboração de um Programa de Prevenção de Riscos Ambientais (PPRA) - agentes físicos, químicos e biológicos existentes nos ambientes de trabalho que possam causar danos à saúde do trabalhador (POSSIBOM, 2001).

De acordo com a Constituição Federal de 1988 (BRASIL, 1989), é de competência do Sistema Único de Saúde (SUS) executar ações relacionadas à saúde do trabalhador. A Lei Orgânica da Saúde (BRASIL, 1990) tem como princípios a universalidade, a eqüidade e a integralidade das ações e serviços de saúde a todos os cidadãos brasileiros, e atribui esse dever ao Estado, não excluindo a responsabilidade das pessoas, da família, das empresas e da sociedade.

Na 2ª Assembléia Nacional de Especialidades Odontológicas (ANEO, 2001), foi sugerida a criação da especialidade Odontologia do Trabalho, cujo anúncio e exercício foram normalizados pela Resolução no 22/2001 do Conselho Federal de 
Odontologia (CFO, 2001), que a define como a especialidade que tem como objetivo a busca permanente da compatibilidade entre a atividade laboral e a preservação da saúde bucal do trabalhador. No ano de 2002, a Resolução CFO n 25/2002 (CFO, 2002) estabeleceu as áreas de competência para a atuação dos especialistas nesta nova área.

Atualmente, as equipes dos SESMT são compostas por: médico do trabalho, enfermeira do trabalho, auxiliar de enfermagem do trabalho, engenheiro do trabalho e técnico de segurança do trabalho. Assim, embora a necessidade e a importância das inter-relações da odontologia do trabalho com as outras áreas voltadas à promoção de saúde do trabalhador sejam reconhecidas, a legislação brasileira ainda não prevê a inserção do cirurgião-dentista do trabalho em tais equipes.

Considerando que a Odontologia do Trabalho tem como foco principal a saúde bucal do trabalhador, bem como o seu estado geral de saúde, a implementação de um programa de atenção em saúde bucal nas empresas pode resultar em maior produtividade, pois a dor, a má alimentação, a falta de sono e a distração mental decorrentes de afecções que acometem a cavidade bucal são, entre outros, fatores que aumentam a ineficiência dos empregados, a ocorrência de acidentes de trabalho e o absenteísmo. 


\section{REVISÃO DA LITERATURA}

\subsection{Saúde e Saúde Bucal}

A Lei Orgânica da Saúde (BRASIL, 1990) estabelece, em seu art. 2̊: "A saúde é um direto fundamental do ser humano, devendo o Estado prover as condições indispensáveis ao seu pleno exercício”.

A preocupação com a saúde é tão antiga quanto a existência do homem. Na antigüidade, os homens acreditavam que ela dependia dos desejos divinos. Posteriormente, e até o final do século passado, a palavra saúde implicava e restringia-se à saúde física (PESSINI; BARCHIF ONTAINE, 1991). Na década de 90 do século XX, a compreensão de saúde foi ampliada, passando a incorporar, além da saúde física, as condições de vida que cercam o homem. Assim, na atualidade, as ações e preocupações com a saúde excedem os limites do corpo, inserindo-se em um contexto sociológico (CROSATO, 2004).

Na definição de Davis (2001), saúde é a condição na qual todas as funções do corpo e da mente estão normalmente ativas.

De acordo com a World Health Organization (WHO, 1946), saúde não implica apenas ausência de enfermidade: é um estado de completo bem-estar físico, mental e social.

Essa definição tem sido objeto de controvérsias. Alguns estudiosos questionam a quem caberia determinar o bem-estar: ao profissional da saúde ou ao 
indivíduo? Isso porque muitas pessoas vivenciam um estado de bem-estar, embora possam ser classificadas como não-saudáveis por outras.

Nesse sentido, Nadanovsky (2000) destaca que a responsabilidade pela manutenção e melhora da saúde é primeiramente do indivíduo, que define e seleciona o estilo de vida que quer levar. Entretanto, e ainda segundo o autor, para que esse indivíduo esteja apto a escolher o melhor para si, é necessário que detenha informações quanto à influência de comportamentos e hábitos deletérios sobre a sua integridade física e emocional.

Para Dejours (1986, p.7), não é possível "pensar" a saúde sem considerar a noção de variabilidade, pois "o funcionamento do homem é a mudança e não a estabilidade". Nessa mesma linha, Sgreccia (1996) pondera que é difícil conceber saúde como um fator estático ou uma medida perfeita. Para esse estudioso, a saúde seria um equilíbrio dinâmico entre os diversos órgãos e as diversas funções da unidade do organismo no âmbito do soma; entre o soma e a psiquê no âmbito do indivíduo; e entre o individuo e o ambiente - não apenas o ambiente social, mas também o ecológico, justamente pela relação existente entre o organismo humano e o ambiente biofísico que o circunda - em um contexto mais amplo.

Já sob uma óptica mais moderna, Assumpção (2004) considera saúde como um estado de relativo equilíbrio de forma e função do organismo, que resulta do ajustamento dinâmico satisfatório deste às forças que tendem a perturbá-lo. E ressalta que esse inter-relacionamento entre a matéria orgânica e as forças que agem sobre ela não é passivo, mas constitui-se em uma resposta ativa do organismo no sentido de reajustamento de suas condições normais. 
Além disso, como lembra Nadanovski (2000), embora os profissionais da área da saúde tendam a lidar com cada doença como se ela fosse independente, a maioria das moléstias tem determinantes comuns.

Assim, e de acordo com Moraes, Dias e Furtado (2004), as preocupações com a saúde geral transcendem os limites da área médica, pois está sobejamente comprovado que um elevado número de doenças sistêmicas decorre do descontrole de predisponentes que escapam à atuação médica.

\subsection{1 a importância da cavidade bucal}

Morada do sorriso e dos dentes, porta de comunicação entre o indivíduo e o mundo, do ponto de vista psicossomático a boca é, provavelmente, o órgão mais importante do corpo humano. Mas sua importância não se limita ao aspecto emocional. Do ponto de vista funcional, a boca é responsável pela articulação dos componentes do processo de mastigação dos alimentos - que irão dar sustentação e manter o equilíbrio da saúde (GUIMARÃES; ROCHA, 1979a) -, pela emissão dos sons e, de forma auxiliar, participa também da respiração. Em virtude de sua localização e das funções que exerce, é uma zona de absorção, retenção e excreção de substâncias tóxicas que penetram no corpo, estando sujeita a agressões de natureza física e/ou mecânica (VIANNA; SANTANA, 2001).

A ação dos dentes reduz os alimentos a partículas, possibilitando que estes sejam digeridos sem maiores desgastes para os demais órgãos do aparelho digestivo. Conseqüentemente, as faltas ou ausências de dentes, ou mesmo as 
articulações defeituosas, implicarão sobrecarga para os demais órgãos do aparelho digestivo, com conseqüências altamente desastrosas a longo e médio prazos (GUIMARÃES; ROCHA, 1979a).

Além disso, a análise anatômica da cavidade bucal pode revelar desde a presença de cáries até processos neoplásicos capazes de levar o indivíduo à morte se não detectados precocemente (GUIMARÃES; ROCHA, 1979a).

Assim, a saúde geral depende do equilíbrio da oclusão, elemento fundamental para a digestão e a nutrição, e da ausência de infecções bucais que freqüentemente passam despercebidas, mas que podem colocar em risco o êxito de outros tratamentos clínicos (DAVIS, 2001).

Thomas (1943) destaca a responsabilidade do cirurgião-dentista quando este realiza o exame bucal do paciente, pois as doenças bucais podem originar infecções em outras partes do corpo. O autor postula que o exame da cavidade bucal deve ser minucioso pois os abscessos dentários são potencialmente perigosos, não apenas pela possibilidade de transferência da infecção e de toxinas para outras partes do corpo, mas também porque causam diminuição da resistência do organismo.

Dentre as afecções que acometem a cavidade bucal, a infecção do periodonto é, de acordo com a grande maioria dos pesquisadores, aquela que maior grau de correlação mantém com outras moléstias de caráter sistêmico.

Lotufo e Panutti (2004, p.43) destacam que a expressão "infecção focal" pode ser definida como "a disseminação de microorganismos e de seus produtos de locais cronicamente infeccionados (como a cavidade bucal) para outros órgãos do corpo". Para esses autores, há evidências que demonstram a possível associação entre algumas doenças sistêmicas - endocardite infecciosa, doenças cardiovasculares, 
controle metabólico do diabetes, doenças respiratórias e nascimento de prematuros, entre outras - e a presença de doença periodontal.

Também Offenbacher e Beck (2004) apontam o grau de significância da carga infecciosa da periodontite sobre o organismo daqueles que por ela são afligidos, lembrando estudos, realizados em humanos e em animais, que apontam a associação entre as infecções periodontais e algumas patologias vasculares e placentárias

Para Grande (2002), os resultados de investigações implementadas por vários estudiosos indicam que a doença periodontal pode representar um fator de risco para doenças crônicas, como aquelas de ordem cardiovascular e cérebrovascular, além da morte de recém-nascidos pré-termo com baixo peso. Assim, a influência da doença periodontal sobre a morbidade e a mortalidade de portadores de moléstias sistêmicas deve ser objeto de novos e mais aprofundados estudos.

De modo geral, a alteração das estruturas dos tecidos periodontais pode ter causas multifatoriais, incluindo fatores locais e sistêmicos. A placa bacteriana é considerada um fator local, desencadeante dos processos inflamatórios, que podem ser agravados ou modificados por fatores sistêmicos (ARMITAGE, 1984).

Seguindo essa linha de raciocínio, Bimstein e Matsson (1999) lembram que, embora vários fatores de ordem sistêmica, como o Diabetes mellitus, possam predispor ao desenvolvimento de doenças periodontais e gengivais inflamatórias, nenhum deles tem a capacidade de induzir a doença periodontal na ausência do biofilme dental.

Mais recentemente, Wehba, Rodrigues e Soares (2004) apontaram o caráter bidirecional da relação existente entre o diabetes e a doença periodontal. Assim, se está comprovado que o diabetes influencia o desenvolvimento e/ou o agravamento 
da doença periodontal, o contrário também é verdadeiro, ou seja, a presença de infecção e/ou inflamação periodontal também influiria no controle glicêmico de pacientes diabéticos.

Para Buischi (2000), as variáveis mais comumente relacionadas à saúde bucal são o consumo de açúcares extrínsecos e o controle efetivo do biofilme dental, mas outros fatores devem ser considerados, como o consumo excessivo de álcool e de fumo, a exposição a fluoretos e o uso apropriado dos serviços de atenção à saúde bucal. E, embora todos esses fatores possam ser modificados individualmente para promover a saúde, eles são diretamente influenciados por aspectos sóciopolíticos complexos, que estão fora do controle da população em geral.

Como afirma Pizzatto (2002), a saúde começa pela boca, e a saúde bucal é parte inseparável da saúde geral.

\subsection{A Relação Saúde e Trabalho}

De acordo com Assunção e Lima (2003), o trabalho é uma atividade que utiliza o corpo inteiro e a inteligência para enfrentar o que não é dado pela estrutura técnico-organizacional.

O ambiente de trabalho compreende todo o conjunto de instalações e condições existentes nos locais onde uma determinada atividade é executada, e traz reflexos à saúde e ao comportamento dos indivíduos que nele atuam, pois influencia o modo de pensar e agir destes últimos. Quando adequado ao trabalhador, proporciona maior produtividade e qualidade para a empresa, diminuindo 
sensivelmente o número de reclamações trabalhistas (PERSONA; PERSONA, 1998).

O processo de trabalho pode provocar, desencadear ou agravar doenças que podem ser caracterizadas como profissionais - adquiridas ou desencadeada pelo exercício do trabalho peculiar a determinada atividade - e do trabalho adquirida ou desencadeadas em função de condições especiais em que o trabalho é realizado e que com ele se relacionem diretamente (BELLUSCI, 1996).

Para Araujo (1998), o local de trabalho é um dos ambientes em que mais freqüentemente ocorre exposição a produtos tóxicos. Em virtude disso, há uma legislação especifica para normatizar as condutas e os procedimentos nesse âmbito, e observa-se um esforço continuado para prevenir os níveis de perigo a que estão expostos os trabalhadores das mais diversas atividades.

Assim, e considerando que a atividade laborativa é um dos espaços de vida determinantes na construção e desconstrução da saúde (ASSUNÇÃO; LIMA, 2003), a preocupação com a influência das condições em que essa atividade se dá sobre o estado de equilíbrio do indivíduo remonta às primeiras civilizações.

De acordo com Mendes (2003), historiadores de medicina puderam detectar referências à relação entre trabalho e saúde-doença em alguns papiros egípcios, nos quais havia indícios de atendimentos médicos organizados em certos locais de trabalho.

A obra "Água, Ares e Lugares", de Hipócrates, já fazia menção a casos de intoxicação por contato com chumbo e, no início da era cristã, Plinius descreveu a utilização de equipamentos de proteção individual (EPI) por escravos. Para se protegerem da poeira existente nas minas de enxofre, esses escravos utilizavam máscaras confeccionadas com bexigas de carneiros (PERSONA; PERSONA, 1998). 
Em "De Re Metallica”, obra de 1556 que descreve aspectos da extração e da fundição de metais - ouro -, Georgius Agrícola faz menção aos acidentes do trabalho e às doenças mais comuns dos mineradores (ENCYCLOPAEDIA..., 1998).

Em 1700, o médico italiano Bernardino Ramazzini publicou o livro "De Morbis Artificum Diatriba", no qual elenca cerca de 54 profissões e descreve os principais problemas de saúde apresentados pelos trabalhadores que as desempenhavam, concluindo que o conhecimento médico das ocupações laborais é fundamental para a adoção de medidas adequadas à preservação da saúde do trabalhador (MAZZILLI, 2003).

O advento da Revolução Industrial concentrou os trabalhadores em um espaço fechado de trabalho e promoveu a supervalorização das máquinas em detrimento do homem, levando as classes trabalhadoras - que já padeciam da falta de cuidados básicos - a uma catastrófica condição de saúde (SEIXAS, 2001).

O trabalhador, anteriormente "livre" para vender sua força de trabalho, tornou-se presa da máquina, de seus ritmos, dos ditames da produção que atendiam à necessidade de acumulação rápida de capital e de máximo aproveitamento dos equipamentos antes que estes se tornassem obsoletos. As jornadas extenuantes, em ambientes extremamente desfavoráveis à saúde - às quais também mulheres e crianças eram submetidas - eram freqüentemente incompatíveis com a vida. A aglomeração humana em espaços inadequados propiciava a proliferação de doenças infecto-contagiosas, ao mesmo tempo em que a periculosidade das máquinas era responsável por mutilações e mortes (MINAYO-GOMES; THEDIMCOSTA, 1997).

Segundo Silva e Souto (1983a), a principal característica do período que teve início com a Revolução Industrial foi a servidão do homem à máquina, que 
obrigava o trabalhador a constantes riscos, enfrentando caldeiras incendiárias e engrenagens mutiladoras. Porém, uma vez que a sociedade industrial dependia - e ainda depende - dos resultados fabris que, por sua vez dependem das atividades operacionais, os tecnólogos se convenceram de que o bem-estar do trabalhador pode aumentar a produtividade da máquina e dele próprio - trabalhador.

Assim, depois da Revolução Industrial, o ambiente de trabalho passou a ser objeto de estudos e de intervenções cujo principal objetivo é proteger a integridade física do trabalhador. Esses primeiros estudos e intervenções foram as bases da engenharia de segurança e da medicina do trabalho (MAZZILLI, 2003).

Em um momento em que a força de trabalho era fundamental á industrialização emergente, a introdução do médico nos processos de produção visava recuperar os trabalhadores para que estes voltassem com rapidez à linha de produção. Portanto, a gênese da Medicina do Trabalho foi marcada por uma visão extremamente biológica e individual, limitada ao espaço restrito da fábrica e a uma relação unívoca e unicausal, buscando as doenças e os acidentes (MINAYOGOMES; THEDIM-COSTA, 1997).

Esse modelo de atuação da medicina do trabalho, centrado apenas na avaliação médica da causa e de seu efeito (nexo causal) e preocupado tão somente com a proteção do trabalhador contra as agressões eminentemente físicas proporcionadas pelo meio laboral, perdurou por décadas (MAZZILLI, 2003).

Entretanto, ao final do século $X X$, observou-se em todo o mundo uma forte tendência no sentido de ampliar o espectro de abrangência da medicina do trabalho (MAZZILLI, 2003). Prova disso é a Convenção no 161, adotada na 71ํㅡ Conferência Internacional do Trabalho (OIT, 1985a), que recomenda que os serviços de Saúde no Trabalho devem ser essencialmente orientados para as ações preventivas, e 
aconselha empregados e empregadores a buscarem ambiente e condições de trabalho seguros e salubres, que favoreçam a saúde física e mental, adaptando o trabalho à capacidade e às condições dos trabalhadores.

Nos anos 90, a Terceira Revolução Industrial ou Reestruturação Produtiva, entendida como uma nova forma de produzir - decorrente dos avanços tecnológicos e de novas formas de organizar e gerir o trabalho -, introduziu mudanças radicais na vida e nas relações dos indivíduos e países e, por conseqüência, no viver e adoecer das pessoas. Esse processo modificou o perfil do trabalho e dos trabalhadores, os determinantes da saúde-doença dos trabalhadores e, em decorrência disso, o quadro da morbimortalidade relacionada ao trabalho e a organização e as práticas de saúde e de segurança no trabalho, ressalta Dias (2002). Para justificar essa assertiva, o autor lembra que o processo saúde-doença dos trabalhadores - como e por que adoecem e morrem, e como são organizadas e atendidas as suas necessidades de saúde - pode ser considerado uma construção social diferenciada, que depende do tempo, do lugar e da organização das sociedades.

Assim é que Dias e Mendes (2000) definem a medicina do trabalho como a especialidade médica que tem por objeto de estudo a relação existente entre a saúde dos trabalhadores e o desempenho do trabalho. Esses mesmos estudiosos entendem que o foco da Medicina do Trabalho excede a simples prevenção de doenças e acidentes laborais, pois compreende também a implementação de ações capazes de assegurar a saúde individual nas dimensões física e mental, e a promoção de uma saudável inter-relação entre as pessoas e entre estas e seu ambiente social, particularmente aquele relacionado ao trabalho.

Para Araujo e Gonini Júnior (1999), a medicina do trabalho é uma especialidade criada não só pelas necessidades da classe trabalhadora, mas 
principalmente por motivos legais, em decorrência da legislação emanada pelo Ministério do Trabalho (MT), que exige exames médicos para a contratação ou a demissão do quadro pessoal de qualquer empresa.

Outra contribuição da $71^{\underline{a}}$ Conferência Internacional do Trabalho (OIT 1985b) foi a redefinição dos serviços de medicina do trabalho, cujo foco era centrado no risco para a saúde do trabalhador, que passaram a ser denominados Serviços de Saúde Ocupacional e a ter como foco a defesa integral da saúde do trabalhador.

Saúde ocupacional, para Silva e Souto (1983a), é o conjunto de procedimentos que visam a promoção e a manutenção do bem-estar físico, psíquico e social do homem no seu trabalho.

Já de acordo com Segre (1989), a saúde ocupacional é uma atividade desenvolvida por uma equipe na qual o médico detém apenas uma parcela das responsabilidades, cuja preocupação vai além da atenção às patologias provenientes do trabalho. Na atualidade, as equipes de saúde ocupacional constituídas por profissionais de diferentes formações - buscam a preservação da saúde como um todo, aí se incluindo os aspectos extra-profissionais.

Esse entendimento é o mesmo de Mazzilli (2003), em trabalho recente. Para esse estudioso, a saúde ocupacional contemporânea compreende a atuação de profissionais formados em diversas áreas do conhecimento, que devem desenvolver e aplicar continuamente seus melhores recursos não só para defender o trabalhador de tudo aquilo que - presente no ambiente de trabalho - possa macular sua saúde, mas também para prover-Ihe meios para alcançar o bem-estar físico, mental e social - em outras palavras, saúde. Entretanto, o autor ressalta que a "atividade ocupacional, também conhecida como atividade de trabalho, não é caracterizada pelo simples e suficiente fato de o Serviço de Saúde ocupar fisicamente as 
instalações da empresa, nem pelo fato de ser ele parcial ou integralmente custeado pela própria empresa" (MAZZILLI, 2003, p.20).

A despeito das diferentes décadas em que foram realizados, os trabalhos de Mazzilli (2003) e Segre (1989) são respaldados pelo documento denominado "Doenças relacionadas ao trabalho: manual de procedimentos para os serviços de saúde", elaborado pelo Ministério da Saúde do Brasil (BRASIL, 2001), que determina que a atenção à saúde dos trabalhadores é fruto da interação de uma equipe multidisciplinar, composta por profissionais de diversas áreas do conhecimento, mantendo um enfoque interdisciplinar. O estabelecimento do nexo causal (ou nexo técnico) entre saúde-doença e trabalho, atual e pregresso, não se limita ao estabelecimento do diagnóstico precoce e do tratamento ideal, mas representa o início de ações no âmbito dos sistemas de saúde, de vigilância e de registro de informações.

No que concerne à obrigatoriedade legal de manutenção dos registros, Vianna e Santana (2001) comentam que até mesmo as empresas localizadas em países do primeiro mundo - como os Estados Unidos da América (EUA) e aqueles que fazem parte do continente europeu - apresentam falhas. Muitas dessas empresas não têm registros sistemáticos sobre a exposição de seus empregados a agentes deletérios à saúde, e/ou sobre o estado de saúde dos trabalhadores ao longo do tempo. Além disso, quando tais registros existem, é freqüente que sua qualidade esteja comprometida, ou que o acesso de pesquisadores às bases de dados seja dificultado, até mesmo em virtude das relações historicamente conflituosas entre empregadores e empregados.

Essa postura de omissão e descaso, e até mesmo de cerceamento dos estudiosos às centrais de informação, traz um outro problema: a inexistência - ou 
insuficiência - de medidas de exposição suportáveis (VIANNA; SANTANA, 2001). Isto porque se sabe que os efeitos decorrentes de exposições ocupacionais sobre a saúde podem variar de acordo com a duração e com a intensidade da exposição, esta última passível de variação ao longo do tempo. Como se não bastasse, outros fatores - como condições ambientais, condições ergonômicas e uso de equipamentos de proteção individual - podem modificar o processo de absorção de agentes tóxicos no contexto da atividade laboral. E, segundo a World Health Organization (WHO, 1992), estima-se que milhões de trabalhadores em todo o mundo estejam expostos a produtos ácidos.

A Lei Orgânica da Saúde (BRASIL, 1990), que regulamenta o texto da Constituição Federal de 1988 (BRASIL, 1989), no seu art. 6ํ, parágrafo $3^{\circ}$, define saúde do trabalhador como "um conjunto de atividades que se destina, através das ações de vigilância epidemiológica e sanitária, à promoção e proteção da saúde dos trabalhadores, assim como visa a recuperação e reabilitação da saúde dos trabalhadores submetidos aos riscos e agravos advindos das condições de trabalho".

De acordo com Lacaz (1997), a saúde do trabalhador é um tema que ainda não atingiu a adolescência, e somente a discussão sobre os rumos a serem tomados fará com que atinja uma maturidade saudável e duradoura. Para o autor, é preciso fazer uma reflexão sobre as diversidades epidemiológicas dos agravos à saúde dos trabalhadores, que variam desde as doenças provocadas pela introdução de novas tecnologias e pela organização do trabalho, passando pelas contaminações por solventes e metais pesados, pela surdez de milhares de operários dos mais diversos ramos de produção, pelas intoxicações e acidentes no trabalho com máquinas, até chegar aos efeitos do trabalho escravo de menores e mulheres sobre a saúde. 
Seguindo essa mesma linha de raciocínio, Dejours (1986, p.7) enfatiza: "estamos relativamente cientes dos males que as condições do ambiente físico de trabalho podem provocar nos trabalhadores: as doenças profissionais ou do trabalho, além dos acidentes propriamente ditos".

Também Araujo e Gonini Júnior (1999) destacam que o agente patogênico pode se constituir em um elemento mecânico, físico, químico ou biológico que gera estímulo em um hospedeiro que tem fatores intrínsecos, moldados por seus hábitos, saúde e ocupação, associados ao meio ambiente físico, biológico, social ou econômico resultando, conforme o desequilíbrio ou não destes fatores, em um processo de doença ocupacional instalada.

Shilling (1984) classificou as doenças relacionadas ao trabalho em três grupos:

- Grupo I: doenças em que o trabalho é a causa necessária, tipificadas pelas doenças profissionais, como é exemplo a intoxicação por chumbo;

- Grupo II: doenças em que o trabalho pode ser um fator de risco contributivo, mas não necessário, como no caso das doenças cardíacas;

- Grupo III: doenças em que o trabalho é provocador de um distúrbio latente ou agravador de doença já estabelecida ou preexistente, como a bronquite crônica.

Já o Instituto Nacional de Previdência Social (BRASIL, 1991) apresenta a seguinte classificação para os agravos à saúde decorrentes do exercício profissional:

- Acidente Típico: acidente decorrente da característica da atividade profissional desempenhada pelo acidentado;

- Acidente de Trajeto: acidente ocorrido no trajeto entre a residência e o local de trabalho do segurado, e vice-versa; 
- Doença Profissional ou do trabalho: aquela produzida e desencadeada pelo exercício do trabalho peculiar a determinado ramo de atividade, constante do anexo II do Regulamento da Previdência Social (RPS);

- Doença do trabalho: aquela adquirida ou desencadeada em função de condições especiais em que o trabalho é realizado e que com ele se relacione diretamente, desde que constante no anexo citado anteriormente.

Em decorrência desse diploma legal, Mazzilli (2003 p. 29) especifica:

Doença profissional é aquela produzida ou desencadeada pelo exercício peculiar a determinada atividade; já a doença do trabalho é aquela adquirida ou desencadeada em função de condições especiais em que o trabalho é realizado, desde que com ele se relacione diretamente.

A empresa deve comunicar o acidente de trabalho ocorrido com seu empregado, havendo ou não afastamento do trabalho, até o primeiro dia útil subseqüente à ocorrência e, em caso de morte, de imediato, à autoridade competente, sob pena de multa variável entre o limite mínimo e o teto máximo do salário de contribuição - sucessivamente aumentada nas reincidências, aplicada e cobrada como preconiza o artigo 286 do Regulamento de Previdência Social, aprovado pelo Decreto $n^{\circ}$ 3.048, de 06 de maio de 1999 (BRASIL, 1999).

Bellusci (1996) define acidente de trabalho como aquele ocorrido pelo exercício do trabalho a serviço da empresa, ou ainda pelo exercício do trabalho dos segurados especiais, provocando lesão corporal ou perturbação funcional que cause morte ou perda ou redução da capacidade para o trabalho, permanente ou temporária.

Considerando que a vigilância dos riscos e a vigilância das doenças não podem ser isoladas uma da outra, interagindo entre si, Machado (1997) cita a importância do estabelecimento do nexo causal entre as condições de trabalho e os casos de doenças. Essa postura encontra respaldo no "Manual de procedimentos 
para os serviços de saúde" elaborado pelo Ministério da Saúde do Brasil (BRASIL, 2001), que determina que o estabelecimento do nexo causal entre a doença e a atividade atual ou pregressa do trabalhador representa o ponto de partida para o diagnóstico e a terapêutica corretos, incluindo ações no âmbito dos sistemas de saúde. A relação causal (nexo) das doenças profissionais (grupo l) é direta e imediata, sendo que a eliminação dos agentes agressores pode assegurar a prevenção do trabalhador. Nos outros dois grupos, as doenças são consideradas de etiologia múltipla, ou seja, decorrem de vários fatores de risco. Por esse motivo, a caracterização do nexo será de natureza epidemiológica, seja pela observação do excesso de freqüência em determinados grupos profissionais, seja pela ampliação quantitativa ou qualitativa do espectro de determinantes causais, que podem ser melhor conhecidos nos estudos das condições e dos ambientes de trabalho.

Portanto, ressaltam Dias e Mendes (2000), para a emissão do diagnóstico correto e a adoção da conduta que resultará em melhor prognóstico, os médicos devem conhecer a(s) ocupação(ões) - atual e pregressa(s) - de seus pacientes.

\subsection{1 saúde bucal do trabalhador}

As afecções que acometem a cavidade bucal são responsáveis por elevados índices de absenteísmo ao trabalho. Em pesquisa qualitativa realizada com usuários do serviço de emergência da faculdade de odontologia de Piracicaba da Universidade Estadual de Campinas, Brito Jr. (2000) verificou os seguintes percentuais para afastamentos decorrentes de intercorrências odontológicas: 3 dias, 
12,7\%; 2 dias, 47,3\% e 1 dia, 30,9\%. Já Martins (2002), que investigou o absenteísmo por causas médicas e odontológicas em duas empresas - uma pública e outra privada - constatou que, de um total de 5.693 dias de afastamento, 89 tinham etiologia odontológica, e que $81,3 \%$ das ausências ao trabalho por motivos odontológicos implicavam faltas de pelo menos um dia.

Investigando os afastamentos do trabalho decorrentes de problemas odontológicos em servidores públicos municipais de São Paulo, Mazzili (2004) obteve tempo médio de ausência de 5,4 dias.

Assim, e como já enfatizava a American Dental Association (ADA, 1946), a realização de estudos que demonstrem a interação absenteísmo-doenças bucais reveste-se de grande importância, pois pode promover o aumento do número de programas de saúde bucal do trabalhador.

É importante não só levantar os problemas bucais que possam afetar diretamente os trabalhadores, mas analisar concretamente a epidemiologia e a patologia desses problemas, além de avaliar o impacto que possam ocasionar em sua qualidade de vida. Isso trará à tona novos elementos interligados à causalidade das doenças e dos porquês de sua maior ocorrência e manutenção em determinados segmentos da sociedade (ARAUJO; GONINI JUNIOR, 1999).

De acordo com Guimarães e Rocha (1979a, p.7)

\begin{abstract}
convém que se faça uma análise da boca no que se refere aos aspectos dimensionais, quando pretendemos colocar o homem que trabalha numa empresa como o braço que a desenvolve e sustenta, capaz de fazê-la progredir na razão direta do seu estado de higidez física e mental, estado que se obtém com os cuidados preventivos da Medicina e da Odontologia do Trabalho.
\end{abstract}

O conhecimento dos riscos que a atividade ocupacional traz à saúde bucal do trabalhador é ainda incipiente, e a divulgação desse conhecimento, seja no meio acadêmico, seja entre os profissionais de serviços - mesmo aqueles que trabalham 
em indústrias, onde exposições ocupacionais são comuns - é ainda mais pobre. (VIANNA; SANTANA, 2001).

Shour e Sarnat (1942) listaram, como alterações bucais potencialmente resultantes de certas exposições ocupacionais, a cárie dentária, as periodontopatias, as lesões da mucosa bucal, as descalcificações e os desgastes dentários, a osteomielite e a necrose óssea, os cânceres da cavidade bucal, além de sinais e sintomas, como a pigmentação de estruturas bucais, a sensação de secura na boca, a perda de sensibilidade e de paladar e a hemorragia. Entre os fatores de ísco apontados, predominavam os agentes químicos.

Alguns sintomas referentes à cavidade bucal presentes em situações de risco são descritos por Possibom (2001). De acordo com o autor, candidatos a exercer atividades que impliquem riscos devem realizar os exames médicos obrigatórios, e aqueles que apresentarem doenças na cavidade bucal, dentes cariados ou comprometidos por focos de infecção serão considerados inabilitados. Isto porque indivíduos expostos a riscos químicos - como fumos metálicos (antimônio, arsênio, chumbo, cobalto, cobre, estanho, ferro, magnésio, mercúrio, níquel e zinco) - podem manifestar gosto metálico e adocicado na boca, irritação da garganta e secura das membranas mucosas, além de gengivites e quedas de dentes; indivíduos expostos a riscos físicos - radiações ionizantes - podem apresentar sérias inflamações na boca. 


\subsubsection{1 doenças bucais ocupacionais}

De acordo com Guimarães e Rocha (1979a), as doenças ocupacionais que apresentam manifestação nas gengivas, nos dentes e nas demais estruturas da cavidade bucal podem ser agrupadas em:

1. doenças devidas à ação direta do agente causal sobre as estruturas da boca, decorrentes da ação direta e externa de agentes químicos, físicos, mecânicos ou biológicos;

2. lesões orais decorrentes de moléstias de caráter sistêmico, que apresentam manifestações na boca até mesmo antes dos sintomas clínicos específicos.

O trabalhador que padece de dores na cavidade bucal terá comprometidos tanto a alimentação quanto o sono, o que implica a diminuição da capacidade produtiva e aumenta a falta de concentração laboral, elevando o risco de acidentes de trabalho (MIDORIKAWA, 2000).

Em virtude da escassez de centros de referência em medicina do trabalho disponíveis a todos, o número exato de trabalhadores afetados por determinadas doenças profissionais é praticamente desconhecido, bem como o quadro epidemiológico de muitas afecções bucais decorrentes da atividade laborativa. $\mathrm{Na}$ verdade, a atenção odontológica restringe-se aos níveis primário, secundário e terciário, respectivamente aos cuidados com o ambiente de trabalho, ao controle periódico da população e ao atendimento prestado em âmbito ambulatorial e hospitalar para os acidentes do trabalho (ARAUJO; GONINI JÚNIOR, 1999).

Para Guimarães e Rocha (1979a, p.9)

É sem sombra de dúvida, que uma grande quantidade das moléstias profissionais tem elevado percentual de manifestação oral, e cabe ao dentista do trabalho saber diagnosticá-las para o primeiro alarme em tempo 
de evitar o agravamento do mal. É ainda evidente que a progressão dos processos de cárie acarretará o aparecimento dos focos de origem dentária, com graves conseqüências para o empregado, que terá a sua saúde abalada e em razão disto, deficiência de produtividade, com insegurança para o exercício profissional, tornando-se tendente aos mais variados acidentes no seu trabalho.Quando o dentista do trabalho, frente a uma manifestação oral da patologia profissional e dos processos de cárie, providencia o imediato atendimento do empregado, estará provendo a sua empresa da segurança e dos meios para não acarretar solução de continuidade do seu processo industrial sem afetar a produtividade. Estará também oferecendo, ao empregado, os meios necessários para evitar o agravamento do seu mal, sem que os sérios problemas sociais conseqüentes do afastamento possam afetar-lhe a vida e a sua família. Esse empregado, tratado a tempo e preventivamente, manterá a sua capacidade laborativa nos níveis desejados.

Vianna e Santana (2001) sistematizaram os resultados de estudos sobre os efeitos bucais decorrentes de exposições ocupacionais a névoas ácidas no período de 1980 a junho de 2000, registrados nas bases de dados MEDLINE, LILACS, SciELO, BBO e DEDALUS. Essa sistematização revelou que a exposição ocupacional a névoas ácidas atinge o tecido dentário, causando perda mineral de origem não bacteriana. Assim, destacam que muitos dos problemas de saúde bucal podem ser conseqüência do exercício profissional, o que deve ser amplamente divulgado para a necessária incorporação às práticas e aos modelos de atenção à saúde bucal.

Alguns agentes químicos produzem efeito tóxico direto quando em contato com os tecidos: essa reação local pode se manifestar sob a forma de processos irritativos, inflamatórios e erosivos nas mucosas bucal, esofagiana, gástrica ou intestinal (ARAUJO, 1998).

A inalação dos gases e vapores de fluoreto pode provocar lacrimejamento, rinite, tosse, expectoração, úlceras localizadas nas gengivas, nas mucosas nasal e conjuntiva, destaca a WHO $(1978,1991)$.

Segundo Mazzilli (2003), as doenças odontológicas profissionais são aquelas provocadas pelo "trabalho" ou pela "ocupação". O autor cita, como exemplos 
de doenças odontológicas dessa ordem, a erosão dentária em profissionais expostos a névoas ácidas, as gengivo-estomatites e alterações dos tecidos moles bucais decorrentes de exposição a metais ou névoas de cádmio, as modificações da coloração característica do esmalte e da dentina pelo produto químico com o qual o trabalhador tem permanente contato, e a destruição dos tecidos dentários pela exposição a vapores corrosivos, que acabam provocando cáries e destruição progressiva do periodonto, concorrendo assim para a perda do elemento dentário e suas conseqüências.

Brunetti (2004) considera de grande importância o conhecimento adquirido por médicos e cirurgiões-dentistas acerca do impacto que as doenças periodontais podem ter sobre as condições sistêmicas e vice-versa, e sugere que os portadores desse tipo de afecção devem ser monitorados, para diminuir e evitar as complicações de ordem sistêmica e a evolução das doenças periodontais.

O trabalhador que apresenta quadro com sintomatologia dolorosa de causa bucal e/ou dentária sente-se desconfortável no trabalho, esteticamente diminuído, e apresenta sinais e sintomas que vão desde a diminuição da atenção (absenteísmo de corpo presente) e a ausência ao trabalho (absenteísmo de corpo ausente) até alterações comportamentais devidas à tristeza, à vergonha e à inibição de sorrir, o que implica problemas de relacionamento com as demais pessoas (MIDORIKAWA, 2000).

Dentes com alterações pulpares - manifestações clínicas de dor aguda, espontânea, localizada ou difusa, pulsátil, reflexa, intermitente ou contínua, e estimulada por alterações térmicas entre frio e quente - tanto podem evoluir rapidamente para a pulpite aguda purulenta quanto avançar mais lentamente para a pulpite crônica, até atingirem o estágio de necrose pulpar - morte da polpa -, que 
implica a perda dos processos metabólicos do dente, de sua vitalidade e de suas defesas naturais. Em todas as situações acima descritas, o trabalhador provavelmente teve queda da produtividade, diminuição da atenção ao trabalho, decréscimo na qualidade da alimentação, na qualidade e na quantidade de sono, alterações de humor e absenteísmo (MIDORIKAWA, 2000).

A presença de ácidos fortes no ambiente de trabalho, lembram Vianna e Santana (2001), pode se dar tanto sob a forma líquida quanto sob a forma de névoas, vapores ou gases. De acordo com tais autores, estas três últimas formas alcançam e danificam mais facilmente as estruturas bucais pela inalação e pela ingestão, ou são absorvidas pelo organismo.

Pacientes que tocam instrumentos musicais e vocalistas estão sujeitos a tipos particulares de afecções orofaciais, como leves traumas nos tecidos, retenção dentária, xerostomia, herpes labial, disfunção temporomandibular e problemas ortodônticos, entre outros (YEO et al., 2002).

De acordo com Araujo (1998), determinadas condições de trabalho interferem na saúde dos trabalhadores, desencadeando alterações na mucosa bucal que, muitas vezes, permitem o diagnóstico precoce de envolvimentos sistêmicos.

No ambiente de trabalho, o homem está exposto a um conjunto diversificado de agentes que podem causar danos à saúde. Nesse sentido, as condições de trabalho são de importância significativa para as estruturas bucais, e podem ocasionar uma série de patologias em conseqüência de exposições de natureza ocupacional (VIANNA; SANTANA, 2001).

Já na primeira metade do século passado, Dória (1941) elencava, sob a óptica pericial, alguns acidentes de trabalho e doenças profissionais que poderiam incidir sobre o complexo estomatognático: 
- Acidentes de Trabalho: lesões dos lábios, da região geniana, do mento, das regiões das glândulas salivares, da língua, do soalho da boca, da região palatina, dos dentes e dos maxilares.

- Doenças Profissionais: intoxicações que mais freqüentemente podem levar a processos patológicos do complexo estomatognático, decorrentes da exposição a agentes como chumbo, mercúrio, níquel e cobre, dentre outros.

Em estudo sobre afastamentos médicos em trabalhadores instalados em plataformas marítimas cuja observação demandou sete anos, Duffy (1996) constatou que a doença bucal é um problema significativo. Os resultados dessa investigação demonstraram que o maior índice de absenteísmo ao trabalho, e conseqüentemente a maior quantidade de horas de trabalho perdidas no Reino Unido decorria de problemas odontológicos.

Westergaard et al. (2001) pesquisaram a hipótese de que a exposição ocupacional a enzimas proteolíticas em trabalhadores de um empreendimento farmacêutico e biotecnológico poderia estar associada à erosão nas faces vestibulares dos dentes. Embora os achados desse estudo não tenham sido suficientes para confirmar tal hipótese, os autores verificaram que a exposição a tais enzimas pode promover a perda de substância dentária, o que requer intervenções terapêuticas.

Segundo Bellusci (1996), dentes que tenham pequenas fissuras em obturações e coroas podem doer agudamente quando o indivíduo é submetido a alterações de pressão atmosférica. 


\subsection{Relação Saúde e Trabalho na Legislação Brasileira}

A primeira lei brasileira a intervir sobre as condições de trabalho foi a Lei de Acidentes de Trabalho, que remonta a 1919 (PERSONA; PERSONA, 1998), e só foi criada pela pressão da classe trabalhadora. Em 1930, no governo de Getúlio Vargas, foi criado o Ministério do Trabalho e, posteriormente, a Inspetoria de Higiene e Segurança do Trabalho, que tinha a competência de coordenar, orientar, controlar e supervisionar as atividades relacionadas à segurança e à medicina do trabalho, aí se incluindo a fiscalização do cumprimento dos preceitos legais e regulamentares em todo o território nacional (PERSONA; PERSONA, 1998).

Os diferentes aspectos que permeiam a saúde do trabalhador vêm sendo progressivamente assumidos pelo Sistema Único de Saúde (SUS), que tem obrigações bem definidas nas esferas federal, estaduais e municipais. Esse movimento teve inicio na década de 1980, graças às reivindicações do movimento sindical e à iniciativa de secretarias municipais e estaduais de saúde, que lutavam pela reforma sanitária e passaram a incorporar ações de atenção integral à saúde dos trabalhadores e de intervenção nas condições e ambientes de trabalho (SÃO PAULO, 2005)

A Constituição Federal de 1988 (BRASIL, 1989) estabelece, como competência do Sistema Único de Saúde, executar ações voltadas à saúde do trabalhador, além de outras atribuições. A Lei Orgânica da Saúde (BRASIL, 1990) tem, como princípios, a universalidade, a eqüidade e a integralidade das ações e serviços de saúde a todos os cidadãos brasileiros. 
O Instituto Nacional do Seguro Social (INSS) é ainda a maior seguradora de acidentes de trabalho do país, garantindo ao trabalhador e a seus dependentes, em caso de incapacidade para o trabalho, a satisfação das necessidades básicas. A legislação reconhece, como danos à saúde dos trabalhadores decorrentes do trabalho: acidentes do trabalho típicos, de trajeto, e doenças profissionais e do trabalho, equiparados para fins de concessão dos benefícios. Ressalte-se, ainda, que quando o trabalhador adoece e necessita ser afastado do trabalho para o esclarecimento e/ou o tratamento de um problema de saúde, o pagamento dos primeiros 15 dias consecutivos é de responsabilidade da empresa, sendo encaminhado ao Seguro Social apenas se o quadro mórbido ultrapassar o décimo sexto dia de afastamento (DIAS, 2002).

A seguir, são apresentados os principais instrumentos e diplomas legais que normatizam a relação trabalho e saúde existentes no Brasil.

\subsubsection{Consolidação das Leis do Trabalho (CLT)}

A primeira versão da Consolidação das Leis do Trabalho, datada de 1 de maio de 1943 (CARRION, 2002) - que disciplina inúmeras questões referentes à saúde do trabalhador, como relações de trabalho, registro do contrato de trabalho, jornada, remuneração, repouso e férias, condições especiais sobre o trabalho de mulheres e menores e as condições de Segurança e Medicina no Trabalho (DIAS, 2002) -, já foi objeto de muitas alterações. No que concerne especificamente à Segurança e Medicina do Trabalho - capitulo V, titulo II -, há a Lei no 6.514/77 e a 
Portaria no 3.214/78 (BRASIL, 1998b), que consolidaram a competência do Ministério do Trabalho de editar normas regulamentadoras (NR).

De acordo com Carrion (2002), os artigos (art.) 157 e 158 da CLT (BRASIL, 1998a) preconizam que é dever das empresas cumprir e fazer cumprir as normas de segurança e medicina do trabalho; instruir os empregados, através de ordens de serviço, quanto às precauções a tomar para evitar acidentes de trabalho ou doenças ocupacionais; adotar as medidas que Ihes sejam determinadas pelo órgão regional competente; facilitar o exercício da fiscalização pela autoridade competente. Aos empregados, cabe observar as normas de segurança e medicina do trabalho, inclusive as instruções referentes às precauções para evitar acidentes do trabalho e doenças ocupacionais, e colaborar com a empresa na aplicação dos dispositivos descritos no capitulo V da CLT.

As Normas Regulamentadoras, que vêm sendo atualizadas continuamente, constituem os parâmetros básicos para a inspeção dos ambientes e das condições de trabalho e a organização das ações pelos empregadores (DIAS, 2002).

2.3.2 Serviço Especializado em Engenharia de Segurança e Medicina do Trabalho (SESMT)

Assim, a preocupação com a saúde do trabalhador foi conquistando espaço, e em 1978 o Ministério do Trabalho, através da Norma Regulamentadora № 4 Serviços Especializados em Engenharia de Segurança e Medicina do Trabalho (SESMT) - da Portaria n. 3.214 (BRASIL, 1998b), estabeleceu a obrigatoriedade de manutenção de serviços especializados em engenharia de segurança e medicina do 
trabalho em empresas que possuam empregados regidos pela Consolidação das Leis do Trabalho. Esses serviços deverão contar com uma equipe constituída por médico do trabalho, engenheiro de segurança do trabalho, enfermeiro do trabalho, técnico de segurança do trabalho e auxiliar de enfermagem do trabalho, obedecendo às regras estabelecidas, mediante o número de funcionários e o grau de risco da empresa (CARRION, 2002).

É exigido do médico do trabalho que integra o SESMT o

certificado de conclusão de curso de especialização em Medicina do Trabalho, em nível de pós-graduação, ou [...] o certificado de residência médica em área de concentração em saúde do trabalhador ou denominação equivalente, reconhecida pela Comissão Nacional de Residência Médica do Ministério da Educação, ambos ministrados por Universidade ou faculdade que mantenha curso de graduação em medicina (BRASIL, 1998b).

Além disso, o Conselho Federal de Medicina (CFM) regulamentou, por meio da Resolução $n^{\circ} 1.488 / 98$ (CFM, 1998), as atribuições específicas do médico que integrar a equipe do SESMT, que devem ser conhecidas e cumpridas por todos aqueles que prestam assistência médica a trabalhadores. Segundo o artigo $1^{\circ}$ da citada resolução, são atribuições dos profissionais que prestam assistência médica ao trabalhador:

$>$ assistir ao trabalhador, elaborar seu prontuário médico e fazer todos os encaminhamentos devidos;

fornecer atestados e pareceres para o afastamento do trabalho sempre que necessário, considerando que o repouso, o acesso a terapias ou o afastamento de determinados agentes agressivos faz parte do tratamento;

$>$ emitir laudos, pareceres e relatórios dos exames médicos e dar encaminhamento, sempre que necessário, para benefício do paciente e dentro dos preceitos éticos, quanto aos dados de diagnóstico, prognóstico e tempo previsto de tratamento (BRASIL, 2001). 


\subsubsection{Comissão Interna de Prevenção de Acidentes (CIPA)}

A CIPA é "um dos principais instrumentos de participação e representação dos trabalhadores na busca de soluções e melhorias nas condições de trabalho" (ANALISTA..., 2000, p.66).

A Comissão Interna de Acidentes do Trabalho tem por objetivo a prevenção de acidentes e doenças decorrentes do trabalho, de modo a tornar compatível permanentemente o trabalho com a preservação da vida e a promoção da saúde do trabalhador (CARRION, 2002).

\subsubsection{Programa de Prevenção de Riscos Ambientais (PPRA)}

A NR-9 exige a elaboração de um programa de Prevenção de Riscos Ambientais - agentes físicos, químicos, biológicos e ergonômicos - existentes nos ambientes de trabalho, que podem causar danos à saúde do trabalhador (POSSIBOM, 2001).

De acordo com Possibom (2001), o PPRA visa a preservação da saúde e da integridade dos trabalhadores por meio da antecipação, do reconhecimento, da avaliação e do conseqüente controle da ocorrência dos riscos. Suas ações devem ser desenvolvidas em cada setor da empresa, sob a responsabilidade do empregador e com a participação dos empregados. Riscos ambientais são os agentes físicos, químicos e biológicos existentes nos ambientes de trabalho que, em 
função da sua natureza, concentração ou intensidade e tempo de exposição, são capazes de causar danos à saúde e à integridade dos trabalhadores.

Possibom (2001) desenvolveu programas baseados nos riscos identificados - elaboração do Laudo dos Riscos Ambientais (LRA) - que serão parte integrante do conjunto de iniciativas da empresa no campo da preservação da saúde e da integridade dos trabalhadores.

Os mapas de risco são instrumentos de análise dos riscos presentes no ambiente de trabalho, mas uma de suas limitações é a abstração das características dos indivíduos que desempenham as atividades, como a divisão sexual no trabalho: os gêneros masculino e feminino apresentam diferenciação de susceptibilidade à exposição a determinados agentes (BRITO, 1997).

O PPRA, obrigatório para todos os estabelecimentos, atribui ao empregador a responsabilidade pelas ações a serem executadas, deve contar com a participação dos funcionários, e deve estar registrado em um documento-base em que são avaliados fatores de riscos físicos - ruído, iluminação, calor, frio, umidade e radiação -, químicos - poeiras, gases, substâncias químicas e biológicos -, vírus, bactérias e fungos (ANALISTA..., 2000).

\subsubsection{Equipamentos de Proteção Individual (EPI)}

Segundo o capitulo V da seção IV - Do Equipamento de Proteção Individual - EPI -, art. 166 da CLT (BRASIL, 1998a), a empresa está obrigada a fornecer gratuitamente aos empregados os equipamentos de proteção individual adequados 
aos riscos ocupacionais, em perfeito estado de conservação e funcionamento, sempre que as medidas de ordem geral não ofereçam completa proteção contra os riscos de acidentes e danos à saúde (CARRION, 2002).

Guimarães e Rocha (1979b) discutem o uso dos EPI, pois entendem que a utilização desses equipamentos não tem como foco a proteção da saúde e dos infortúnios decorrentes da atividade laboral, mas sim a eliminação do adicional de insalubridade.

\subsubsection{Programa de Controle Médico de Saúde Ocupacional (PCMSO)}

Ainda na Portaria no 3.214/78 (BRASIL,1998b), a NR-7 tem como objetivo promover e preservar a saúde do trabalhador, estabelecendo obrigatoriedade de elaboração e implementação do Programa de Controle Médico de Saúde Ocupacional, por parte de todos os empregadores e instituições que admitam trabalhadores como empregados (POSSIBOM, 2001).

A versão original das NRs desobrigava as pequenas empresas do cumprimento da legislação pertinente, permitindo que se agrupassem e constituíssem um SESMT para atendimento coletivo. A nova NR-7 e a nova NR-9, de 30/12/1994 (POSSIBOM, 2001), estabeleceram a necessidade de existir o PCMSO, assim como o PPRA, independentemente do número de funcionários, graus de risco e tamanho das empresas (ASSUMPÇÃO, 2004).

Partindo de estudos epidemiológicos de caráter preventivo, o PCMSO prioriza a preservação da saúde do trabalhador vinculado à empresa frente a 
situações de risco iminente. Esse programa deve ser multi-setorial, isto é, envolver todos os setores da empresa. A política empresarial deve ser orientada quanto à necessidade de apoio ao programa - participação da Diretoria e dos Administradores na implantação do programa -, estabelecendo a responsabilidade de cada membro da empresa, de acordo com os níveis hierárquicos: Diretoria, CIPA, SESMT e trabalhadores (ASSUMPÇÃO, 2004).

Na elaboração do PCMSO devem, obrigatoriamente, estar previstas ações de saúde primárias - desenvolvidas antes da instalação do processo de doença - e secundárias - período patogênico, visando o diagnóstico precoce e a recuperação da saúde do trabalhador nesse período -, para garantir a promoção e a prevenção da saúde de todos os trabalhadores da empresa, inclusive com palestras e treinamentos (ASSUMPÇÃO, 2004).

Os papéis e as responsabilidades dentro do PCMSO estão bem definidos: ao empregador cumpre garantir que este seja elaborado e implementado na sua empresa, custeando todos os procedimentos necessários; ao médico coordenador, compete a realização de todos os exames previstos, ou de atribuí-los a profissionais médicos e serviços de propedêutica complementar competentes para a sua execução (DIAS, 2002).

De acordo com Possibom (2001), o PCMSO deve seguir um planejamento que apresente ações de saúde a serem executadas durante o ano, levando em consideração questões incidentes sobre $o$ indivíduo e a coletividade de trabalhadores. Além disso, é necessário elaborar um relatório anual do Programa, que discrimine, por setor da empresa, o número e a natureza dos exames médicos, incluindo avaliações clínicas e exames complementares, estatísticas de resultados 
considerados anormais, e planejamento para o próximo ano - que deve ser reavaliado sempre que ocorrerem alterações dos riscos ambientais na empresa.

E, reiterando a posição anteriormente explicitada, Brito (1997) postula que o PCMSO e a Vigilância em Saúde do Trabalhador devem possuir um enfoque que contemple as diferenças entre os gêneros feminino e masculino, com ações direcionadas a esse aspecto.

Os exames médicos ocupacionais, de acordo com Possibom (2001) devem obedecer aos prazos e à periodicidade abaixo descritos:

$>$ exame médico admissional: realizado antes que o trabalhador assuma as suas atividades;

> exame médico periódico: de acordo com os intervalos mínimos de tempo, conforme a faixa etária, o tipo de exposição e as peculiaridades das condições de trabalho;

$>$ exame médico de retorno ao trabalho: realizado obrigatoriamente no primeiro dia de volta ao trabalho de trabalhador ausente por período igual ou superior a 30 (trinta) dias por motivo de doença ou acidente, de natureza ocupacional ou não, ou parto;

exame médico de mudança de função: realizado obrigatoriamente antes da data da mudança;

exame médico demissional: realizado obrigatoriamente antes da data de homologação, desde que o último exame médico ocupacional tenha sido realizado há mais de:

- 135 (cento e trinta e cinco) dias para as empresas de graus de riscos 1 e 2, segundo o Quadro I da NR-4; 
- 90 (noventa) dias para as empresas de graus de riscos 3 e 4, segundo o Quadro I da NR-4;

Os exames ocupacionais, principalmente o exame periódico, são de extrema importância, pois se constituem em ação educativa de reforço aos programas implantados, informam e formam o trabalhador, detectam novos riscos e doenças, e também são instrumentos de avaliação dos resultados dos programas implantados (PAULO; CURY; FERREIRA JUNIOR, 2002).

\subsection{Odontologia do Trabalho}

Como anteriormente mencionado, e a despeito das controvérsias sobre essa definição, a WHO (1946) estabelece que saúde é um estado de completo bem-estar físico, mental e social.

Partindo de tal premissa, Silva e Souto (1983a) consideram o homem como um complexo biopsicossocial indivisível. Do ponto de vista psicossomático, a boca coloca a odontologia ocupacional como atividade não somente técnico-cientificaartesanal mas também psicodinâmica, visto que modificações nas tensões emocionais não liberadas satisfatoriamente trazem reflexos no organismo, por distúrbios das funções dos órgãos, tais como secreções, circulação, motilidade e resistência a agentes traumáticos; na mente, por emoções, sentimentos e afetos de várias naturezas; no plano social, por distúrbios de interação do indivíduo com os meios familiar e social. 
Com base nessa visão integrada de saúde, Pizzatto (2002, p.75) destaca "[...] a Odontologia passa a assumir relevante papel no que tange à saúde do trabalhador, uma vez que é de conhecimento popular que a saúde começa pela boca, e que a saúde bucal é parte inseparável da saúde geral”.

Entretanto, o conhecimento dos riscos que a atividade ocupacional traz à saúde bucal do trabalhador é ainda incipiente, e a divulgação desse conhecimento, seja no meio acadêmico, seja entre os profissionais de serviços - mesmo aqueles que trabalham em indústrias, onde exposições ocupacionais são comuns - é ainda mais pobre. Isso implica a necessidade de incorporar profissionais especializados na área de odontologia do trabalho nas equipes de saúde e segurança do trabalhador e de higiene industrial. É importante também o deslocamento do foco de atenção do profissional de odontologia da boca para o individuo, e deste para o coletivo, na expressão de sua complexidade social (VIANNA; SANTANA, 2001).

Para Araujo e Gonini Junior (1999), embora o atual momento seja marcado por equipes mais eficientes de Medicina do Trabalho, compostas pelo médico do trabalho, pela enfermeira do trabalho, pela auxiliar do trabalho, pelo psicólogo do trabalho, pelo engenheiro de segurança do trabalho, pelos educadores sanitários e pelos químicos, não há qualquer referência legal ao cirurgião-dentista do trabalho como integrante de tais equipes.

Tais autores reforçam a idéia de que a inclusão da Odontologia no Programa de Controle Médico de Saúde Ocupacional, normatizado pela NR-7 (POSSIBOM, 2001) adotada pelo Ministério do Trabalho, além de atestar a saúde bucal no âmbito ocupacional, possibilitaria a criação de um banco de dados para a área odontológica. Além disso, a participação do cirurgião-dentista na expedição dos exames médicos admissionais e periódicos promoveria a criação de uma nova 
especialidade, incrementaria o mercado de trabalho, favoreceria a ampliação de investigações científicas no âmbito da odontologia social e, conseqüentemente, auxiliaria a democratização dessa ciência.

O anexo 6 "A" da NR-15 (ATLAS, 2001, p.165), que contempla as atividades e operações insalubres, dispõe que deve fazer parte do exame médico a avaliação dos dentes dos candidatos:

Os candidatos devem possuir número suficiente de dentes, naturais ou artificiais e boa oclusão, que assegurem mastigação satisfatória. Doenças da cavidade oral, dentes cariados ou comprometidos por focos de infecção podem também ser causas de inaptidões. As próteses deverão ser fixas, de preferência. Próteses removíveis tipo de grampos poderão ser aceitas, desde que não interfiram com o uso efetivo dos equipamentos autônomos (válvulas reguladoras, respirador) e dependentes (tipo narguillé). Os candidatos, quando portadores desse tipo de prótese, devem ser orientados para removê-las quando em atividades de mergulho.

De acordo com Calvielli (1997), a profissão de cirurgião-dentista no Brasil é regida pela Lei Federal $\mathrm{n} .^{\circ}$ 5.081, de 1966, que regulamenta o exercício da odontologia em todo território nacional:

Art. 20: O exercício da Odontologia só é permitido ao cirurgião-dentista habilitado por escola ou faculdade oficial ou reconhecida, após o registro do diploma na Diretoria do Ensino Superior, no Serviço de Fiscalização da Odontologia, na repartição Sanitária estadual competente e inscrição no Conselho Regional sob cuja jurisdição se achar o local de sua atividade.

Entre outros, o art. 6ำ, inciso III determina que: "Compete ao cirurgiãodentista: atestar, no setor de sua atividade profissional, estados mórbidos e outros, inclusive para justificação de faltas ao emprego".

Davis (2001) define medicina dental como o ramo da medicina envolvido com a preservação e o tratamento dos dentes e de outros tecidos orofaciais, consistindo em medidas preventivas como a higiene oral, bem como em procedimentos ou práticas e cirurgias de restauração. A reabilitação promovida pela restauração, pelo equilíbrio da oclusão e pelo controle de infecções orais e dentais 
que em muitos casos passa desapercebida, acarreta melhor nutrição, digestão e contribui para a manutenção da saúde mental.

Segundo Mazzilli (2003), o Conselho Federal de Odontologia, a partir de 1999, demonstrou firme propósito de inserir a Odontologia no Programa de Controle Médico em Saúde Ocupacional da Secretaria de Segurança e Saúde do Trabalho (SSST) do Ministério do Trabalho.

No âmbito das discussões da II Assembléia Nacional de Especialidades Odontológicas (ANEO, 2001), foi apresentada em sete reuniões plenárias preparatórias nos estados e posteriormente aprovada, a proposição da especialidade de Odontologia do Trabalho, em sessão plenária nacional.

A Resolução CFO nำ 22 (CFO, 2001) define essa nova especialidade:

Art. 30. Odontologia do Trabalho é a especialidade que tem como dbjetivo a busca permanente da compatibilidade entre a atividade laboral e a preservação da saúde bucal do trabalhador.

A Resolução CFO no 25 (CFO, 2002) define as áreas de competência da nova especialidade:

Art. $3^{\circ}$. As áreas de competência para atuação do especialista em Odontologia do Trabalho incluem:

a) identificação, avaliação e vigilância dos fatores ambientais que possam constituir risco á saúde bucal no local de trabalho, em qualquer das fases do processo de produção;

b) assessoramento técnico e atenção em matéria de saúde, de segurança, de ergonomia e de higiene no trabalho, assim como em matéria de equipamentos de proteção individual, entendendo-se inserido na equipe interdisciplinar de saúde do trabalho operante;

c) planejamento e implantação de campanhas e programas de duração permanente para educação dos trabalhadores quanto a acidentes do trabalho, doenças ocupacionais e educação em saúde;

d) organização estatística de morbidade e mortalidade com causa bucal e investigação de suas possíveis relações com as atividades laborais;e,

e) realização de exames odontológicos para fins trabalhistas."

A Resolução CFO no 53 (CFO, 2004), que regulamenta os cursos de especialização em odontologia, em seu art. 156, estabelece, dentre outras determinantes, que o curso de especialização em odontologia do trabalho deve ter 
500 horas-aluno. Segundo o art. 163 do mesmo documento, "o CFO concederá reconhecimento a curso de especialização promovido por instituição de ensino superior, e credenciamento a curso de especialização promovido por entidade da classe registrada no CFO".

"A Odontologia do Trabalho tem por objeto de estudo os riscos à saúde do complexo bucomaxilofacial decorrentes da prática do trabalho, bem como as implicações das doenças e condições odontológicas nas questões laborais" (MAZZILLI, 2003, p.78).

Segundo Silva e Souto (1983a), a proposta da Odontologia Ocupacional é somar esforços às demais especialidades nos cuidados com a segurança e a saúde do trabalhador.

Crosato et al. (2005) esclarecem que a odontologia do trabalho não trata da saúde ocupacional do cirurgião-dentista, e sim das relações entre a saúde bucal e o trabalho (ocupação): portanto, o objeto de estudo dessa especialidade é a profilaxia dos riscos à saúde do complexo bucomaxilofacial decorrentes da prática do trabalho, bem como as implicações das doenças e condições odontológicas nas questões laborais.

\subsection{1 capacitação profissional para a odontologia do trabalho}

Segundo Ramazzini (1992), o médico deve manter a mesma conduta com todos os pacientes, sejam eles melhor aquinhoados financeiramente, sejam eles de classes sócio-econômicas mais baixas. A ética profissional exige um mesmo 
comportamento, independentemente da escala social do indivíduo a ser atendido. Assim sendo, o atendimento ao trabalhador há que ser pautado pela ética: tanto quanto os demais profissionais, o médico que atende trabalhadores operacionais deve demonstrar interesse, preocupação e, efetivamente, realizar um exame acurado e minucioso, porque optou por essa carreira, escolheu a especialidade, e a sua sobrevivência também - ou exclusivamente - depende desse tipo de atividade. É uma atividade essencialmente clínica em que, [sic] o dentista do trabalho,
com orientação psicossomática, se ocupa da personalidade, das emoções,
dos estados de ânimo e sentimentos de temor e de dor, dos sintomas de
enfermidades reais, produzidas direta ou indiretamente pela boca, dentes e
gengivas. Poderíamos concluir que o papel do dentista do trabalho é o
restaurador do direito de sorrir do homem da empresa. Sorrir sem precisar
esconder a boca, sem sentir pudor, vergonha ou sofrimento ultrajante por
não ter a sua boca limpa para poder se abrir na leveza da alegria.
Considerar a significação emocional da boca é tornar consciente que a
atuação do odontólogo do trabalho é muito mais do que a função mecânico-
protética e técnico-manual. Por todos esses fatos, compreende-se
facilmente como convém à empresa que os seus empregados gozem de um
equilíbrio físico-mental, a par do equilíbrio sócio-econômico
(GUIMARÃES; ROCHA, 1979a, p.8)

Para Araujo (1998), o trabalho de educação e convencimento dos cirurgiõesdentistas como profissionais de saúde tem início nos cursos de graduação, que devem transmitir, em seus conteúdos, a necessidade e a importância da saúde bucal dos trabalhadores, e a importância de um diagnóstico bem fundamentado.

Para o exercício desse mister, segundo Guimarães e Rocha (1979a), o cirurgião-dentista do trabalho necessita conhecer qual a participação do funcionário na empresa. Dessa forma, três fatos têm que ser do seu pleno conhecimento, antes mesmo de qualquer providência odontológica: o local de trabalho, o processo de fabricação e as funções que desempenha.

Brock (1958) destaca a importância da interação entre o serviço odontológico industrial e o serviço médico industrial e pondera que, para atuar nessa área, o cirurgião-dentista deve ter qualificação e experiência adquiridas em treinamento prévio. 
Da mesma forma que o médico, o cirurgião-dentista do trabalho contribui com a sua participação, elucidando dúvidas e levando esclarecimentos ao empregado, fazendo com que ele colabore sistematicamente para a obtenção do fim desejado, que é o de proteger a sua própria saúde (GUIMARÃES; ROCHA, 1979b).

\subsection{2 vantagens da odontologia do trabalho}

Para Araujo e Gonini Junior (1999), a odontologia do trabalho define, a médio prazo, um novo campo de atuação profissional, que fornecerá dados epidemiológicos que definirão as medidas de controle necessárias para a elaboração de um programa de saúde que seja ideal ao trabalhador.

De acordo com Guimarães e Rocha (1979a), a presença do cirurgiãodentista do trabalho em uma empresa apresenta vantagens para as duas parte envolvidas - empresa e trabalhador - e até mesmo para o país, a saber:

\subsubsection{1 para o trabalhador}

$>$ aprendizado das regras de higiene bucal que contribuirão para a diminuição do índice de cáries e das conseqüências das doenças profissionais;

$>$ recebimento de tratamento odontológico, com a eliminação dos processos de cárie, diminuindo o numero de extrações; 
$>$ cessação da dor, uma das principais causas de acidentes do trabalho, e suas conseqüências de caráter social e econômico;

obtenção de melhoria geral de sua saúde, pela eliminação dos focos dentários e pela possibilidade de melhor mastigação e melhor aproveitamento dos alimentos;

$>$ aumento do seu potencial de produtividade em face de um estado geral mais equilibrado pelos tratamentos preventivos de que é alvo.

\subsubsection{2 para a empresa}

$>$ diminuição acentuada do índice de absenteísmo;

maior produção, decorrente do equilibrado estado geral dos seus empregados, e conseqüente produtividade individual;

$>$ diminuição dos problemas dentários;

$>$ diminuição dos acidentes de trabalho, evitando soluções de continuidade no desenvolvimento dos serviços;

possibilidade de promover a programação das extrações sem prejuízos para o serviço, evitando que o empregado falte em dias que não deveria;

$>$ redução das despesas na declaração de imposto de renda; 


\subsubsection{3 para o país}

$>$ diminuição da procura por órgãos governamentais que prestem serviços odontológicos;

$>$ diminuição dos índices de acidentes de trabalho e de absentismo, com aumento da produção e conseqüente aumento da oferta do produto industrializado;

aumento da disponibilidade dos seus serviços assistenciais, por ter sido liberado do atendimento ao trabalhador, proporcionando maior dedicação a outras categorias de beneficiários.

\subsection{Programas de Promoção em Saúde}

Segundo Nadanovsky (2000), promoção de saúde é uma ação global que gera melhoria na qualidade de vida das pessoas, e a saúde bucal é parte dessa qualidade de vida.

Nos países desenvolvidos, ponderam Paulo, Cury e Ferreira Júnior (2002), as empresas compradoras de planos de saúde ou seguros saúde para seus funcionários foram as primeiras a investir na saúde no trabalho, uma vez que a gestão de saúde - e não de doenças - tem como resultado a melhoria da qualidade de vida da população, o aumento de produtividade nas empresas, a diminuição do absenteísmo e, conseqüentemente, a redução dos gastos com assistência médicohospitalar. O investimento na promoção de saúde e na prevenção de doenças é 
cada vez mais uma necessidade, sendo responsabilidade de todos aqueles que atuam na área.

Para Assunção e Lima (2003), criar novas abordagens é parte de um processo que pretende fazer avançar as práticas preventivas dos danos à saúde relacionados ao trabalho. A medicina do trabalho estuda a dimensão clínicoocupacional dos problemas de saúde derivados do trabalho e participa da elaboração de medidas de prevenção pertinentes, a biologia estuda as células, a psicologia está direcionada aos aspectos psíquicos, a sociologia aos aspectos de relacionamento social, a epidemiologia e a higiene do trabalho debruçam-se sobre os fatores de risco presentes nos ambientes de trabalho, e a segurança estuda os atos e as condições inseguras aos trabalhadores.

"O estudo da relação risco-doença é frutífero quando se trata de fatores específicos, mas grande parte dos problemas de saúde ligados ao trabalho não é específica" (ASSUNÇÃO; LIMA, 2003, p.1782).

\subsection{1 programas de promoção em saúde bucal}

O Código de Ética Odontológica (CFO, 2003) cita, em seu capítulo III - Dos Deveres Fundamentais, art. 5ํㅜㄴ inciso VII: "promover a saúde coletiva no desempenho de suas funções, cargos e cidadania, independente de exercer a profissão no setor público ou privado".

Silva e Souto (1983a, b, c) destacam a importância da saúde bucal na produtividade, na prevenção de acidentes de trabalho e no controle do absenteísmo, 
e também sugerem medidas que permitam às empresas assumirem sua parcela de responsabilidade no que diz respeito aos programas de saúde, contribuindo para o desenvolvimento nacional através da cooperação com o Estado, na busca por melhores condições de vida e equilíbrio social.

O exame bucal periódico, bem com a implementação de ações educativas destinadas a esclarecer o trabalhador sobre a importância da cavidade bucal, são objeto da reflexão de Walls e Bethlem (1942), que postulam que a profilaxia deve ser realizada pelo cirurgião-dentista ou pela higienista. Além disso, tais autores lembram que, quando os empregados sofrerem injúrias nos dentes ou no tecido de suporte, e quando desenvolverem manifestações bucais decorrentes de doenças profissionais, devem ser examinados pelo cirurgião-dentista e encaminhados ao hospital ou ao cirurgião-dentista particular.

Araujo (1998, p.89) conceitua saúde bucal dos trabalhadores como

a parte da atenção à saúde do trabalhador, que trata de promover,
preservar e recuperar a saúde bucal do trabalhador, conseqüente dos
agravos, afecções ou doenças do exercício profissional, e que tem
manifestações bucais, devendo ter sua ação voltada à prevenção de todos
os agravos laborais, ou seja, objetiva a prevenção de doenças decorrentes
da atuação profissional e dos acidentes do trabalho.

A autora afirma que a atenção primária em saúde bucal do trabalhador é da maior importância, seja ela realizada mediante cuidados com o ambiente do trabalho ou através de controles periódicos da população, visando o diagnóstico precoce das doenças ocupacionais ou não, e a correção dos métodos de segurança do trabalho, quando necessário.

Ainda de acordo com Araujo (1998), ações importantes no âmbito legal compreenderiam tornar compulsório o acompanhamento, pelo cirurgião-dentista, das condições e tratamentos de saúde bucal dos trabalhadores em cada indústria, e exigir a participação desse profissional nas CIPAS. 
No início do século XX, relata Pettiboni (1923), mais de 100 indústrias norteamericanas já ofereciam assistência odontológica gratuita aos seus empregados. Entendia o autor que os consultórios odontológicos gratuitos de indústrias deviam ser sediados nos locais de trabalho.

Para avaliar a existência e as características de serviços odontológicos em indústrias norte-americanas, Dunning (1942) investigou 869 empresas, das quais 163 ofereciam tais serviços a seus funcionários. Os resultados demonstraram que a maioria dessas empresas não deduzia dos salários dos empregados o tempo gasto com os tratamentos e custeava os exames, a profilaxia e uma pequena gama de tratamentos.

Em estudo realizado em 116 empresas que possuíam serviço odontológico, Walls e Bethlem (1942) verificaram que todas tinham mais de 100 empregados, estavam satisfeitas com seu plano, e recomendavam a aplicação de programas semelhantes a outras empresas.

A American Dental Association (ADA, 1942) publicou proposta apontando as condições mínimas para a implementação de serviços odontológicos em indústrias: assegurar eficientes cuidados ao empregado que necessite de tratamento odontológico emergencial decorrente de acidente ocupacional, ou que tenha desenvolvido manifestação bucal em virtude de doenças ocupacionais; garantir o acesso de todos os empregados aos tratamentos odontológicos; manter ações educativas junto aos trabalhadores, orientando-os quanto à importância da saúde bucal; realizar exames odontológicos em todos os trabalhadores; manter os prontuários preenchidos de forma completa e cuidadosa, facilitando a sua compreensão e acesso ao empregado, ao serviço médico e às agências governamentais e possibilitando assim a realização de análises estatísticas e 
comparações; contratar profissionais qualificados nas respectivas áreas de atuação; responsabilizar-se pela qualidade dos serviços executados. Ainda de acordo com o citado documento, os cirurgiões-dentistas que militam no campo da saúde ocupacional devem ter conhecimento da rotina e dos processos industriais, e estar atentos aos sinais bucais provocados por agentes ambientais inerentes à atividade laboral.

Acenando com o aumento da produtividade nas indústrias, Dunning (1942) apresentou um plano de implantação de serviços odontológicos para empresas com 1.000 ou mais empregados, com base no padrão da American Dental Association.

Para Thomas (1943), o serviço odontológico - que deve integrar os serviços de saúde industrial - tem como atribuições: diagnosticar doenças bucais em estágios iniciais; detectar manifestações bucais de doenças profissionais comunicando a área médica para tratamento -; cuidar de todas as condições cirúrgicas traumáticas da boca; manter as fichas odontológicas dos empregados cujo valor para a identificação de indivíduos, em situações de calamidades, é inestimável -; e promover ações preventivas e de educação em saúde bucal aos trabalhadores. De acordo com esse estudioso, o serviço odontológico é um prérequisito para que o serviço de saúde da empresa seja considerado completo.

É de extrema importância prevenir os efeitos nocivos das condições de trabalho e suas influências sobre a saúde, sendo que a prevenção deve sempre se antecipar à ocorrência dos agravos, definida a partir do mapeamento de riscos do trabalho; conscientizar o trabalhador sobre a importância da preservação da saúde bucal, fator significante da saúde geral; diagnosticar precocemente enfermidades especificas ou sistêmicas com manifestações bucais correlacionadas ao ambiente de trabalho; contribuir com as demais áreas profissionais da saúde e segurança do 
trabalho, em todas as ações que visem preservar a integridade do trabalhador (ARAUJO; GONINI JUNIOR, 1999).

Das muitas vantagens em se prover ou facilitar a assistência odontológica a trabalhadores, observa-se predominantemente a melhora de seu bem-estar físico, mental e social, o que implica um significativo aumento do estímulo e da satisfação laboral, com conseqüente redução do absenteísmo e aumento de produtividade. (MAZZILLI, 2003).

A importância de iniciativas que atendam às demandas da sociedade com relação à implementação de programas de odontologia industrial já era destacada por Petty (1943) na primeira metade do século passado. Àquela época, o autor definia a odontologia industrial como um serviço pago pelo empregador e administrado por um ou mais cirurgiões-dentistas em uma clinica - com salário ou com tarifas fixadas - e sujeito à contribuição voluntária ou involuntária do empregado.

Guimarães e Rocha (1979a, p.9) propõem a promoção de exames periódicos de avaliação odontológica em todos os empregados para reconhecer as suas reações físico-psicológicas, através do registro das ocorrências que caracterizam os índices ideais para os serviços que executam. Paralelamente a tudo isso, a orientação sobre noções básicas de higiene dental e a conscientização da importância dos dentes nos aspectos acima descritos contribuirão para um futuro mais produtivo e salutar. Esses mesmos autores definem a odontologia do trabalho como "a parte da odontologia que trata de promover, preservar e reparar a saúde do trabalhador conseqüente dos agravos, afecções ou doenças advindas do exercício profissional e que se manifestam na boca".

É primordial analisar cada individuo de forma pessoal e global, avaliar os riscos e a atividade por anamnese direcionada e testes, remover os problemas emergenciais, e trabalhar no controle dos fatores 
predisponentes, em conjunto com o indivíduo, de forma a eliminar a necessidade de repetir intervenções invasivas (GRANDE, 2002, p.5).

Para avaliar o valor dos programas de saúde bucal no local de trabalho, Westerman (1993) levantou os dados de um grupo de trabalhadores australianos, e concluiu que o sistema baseado na prevenção e manutenção é mais apropriado do que a prática dental propriamente dita.

Os estudos e pesquisas sobre a relação saúde e trabalho devem ter como princípio a valorização do homem. O significado do trabalho na sociedade é, essencialmente, a maneira pela qual os homens integram-se, criam bens e transformam a realidade (SEIXAS, 2001, p.97).

O planejamento deve buscar a integração de todas as áreas da empresa, mediante a atitude participativa de seus componentes, que deve ser contínua e flexível, estando sujeita à reavaliação quando se mostrar necessário, visando sempre alcançar os objetivos pré-estabelecidos (SEIXAS, 2001).

Ainda de acordo com Seixas (2001), a rotina de trabalho em empresas que, embora tendo como atividade principal outros setores, possuem divisões especificamente voltadas ao atendimento odontológico, implica a convivência com um grupo de profissionais. São formadas equipes multidisciplinares, compostas por cirurgiões-dentistas, médicos, psicólogos, assistentes sociais, enfermeiros, engenheiros de segurança e outros, que atuam no mesmo espaço físico e que têm, como objetivo comum, melhorar a qualidade de vida de seus funcionários, aumentar a produtividade e auferir maiores lucros.

Para Frazão e Narvai (2001), a promoção de saúde bucal é um processo social de produção de condições gerais de vida e de trabalho favoráveis ao desenvolvimento sadio da boca, compreendida em sua integralidade biológica e social. Os autores citam ainda a $2^{a}$ Conferência Nacional de Saúde Bucal (CNSB, 1993) “[...] a saúde bucal é parte integrante e inseparável da saúde geral do 
indivíduo e está relacionada diretamente com as condições de saneamento, alimentação, moradia, trabalho, educação, renda, transporte, lazer, liberdade, acesso e posse de terra, aos serviços de saúde e à informação" (FRAZÃO; NARVAI, 2001, p.27).

De acordo com Seixas (2001), administrar um programa inclui coordenar os recursos humanos, materiais, econômicos, o tempo e o espaço, para atingir o objetivo proposto, constituindo um processo de planejamento, organização e controle.

Guimarães e Rocha (1979b) postulam que, para a implementação de serviços especializados em odontologia em uma empresa, mister se faz a fixação de uma política de saúde ocupacional que atenda aos interesses empresariais, tendo em vista os seus principais objetivos. Para que isso ocorra, não se deve esquecer que como conceito básico, a prestação dos serviços na área de saúde só se justifica na medida em que atenda a mandamentos legais, ou que seja indispensável ao incremento de produtividade do pessoal. Sob o aspecto legal da questão, a Portaria nº 3.214 (BRASIL, 1998b) fornece normas reguladoras à segurança e medicina do trabalho. Ela impõe obrigatoriedade, às empresas sujeitas às disposições da Consolidação das Leis de Trabalho - privadas ou públicas -, e aos órgãos da administração direta ou indireta com empregados cujas atividades estejam nela relacionados, a manterem serviço especializado em medicina do trabalho, obedecida a graduação do risco ali constante.

O programa de saúde bucal deve atender o indivíduo com um todo, e não somente como alguém com dentes doentes. Para funcionar adequadamente, qualquer programa de atenção odontológica deve avaliar os critérios utilizados nos levantamentos dos dados, considerando singularidades relacionadas ao tempo de 
avaliação, aos critérios envolvidos para o diagnóstico de doenças bucais e à faixa etária dos trabalhadores (PEREIRA, 2003).

Para tornar possível a atividade proposta como fonte de informações epidemiológicas relacionadas às doenças profissionais, no exame clinico rotineiro e obrigatório do PCMSO deveria ser incluído o exame odontológico, utilizando-se inicialmente uma ficha simplificada da Organização Mundial de Saúde apresentada por Pinto (1994), da qual constam exames de dentes, mucosa e articulações, além da possibilidade da utilização do Código Internacional de Doenças (CID), postulam Araujo e Gonini Junior (1999). Esse exame, constante do prontuário médico, favoreceria o cruzamento de informações pessoais e do local de trabalho, auxiliando no desenvolvimento de uma lista de verificação de possíveis doenças por função, semelhantemente ao que propõem Shour e Sarnat (1942).

Nos últimos anos, grande enfoque tem sido dado à promoção de saúde bucal e, para cumprir o objetivo de manter a comunidade com boas condições de saúde bucal, a odontologia terá que expandir ainda mais seus horizontes, inovando suas ações de maneira que, gradativamente, seja menos necessária como uma prática de cura e mais necessária como um fator de prevenção e bem-estar (PINTO, 1990).

Segundo Crosato (2004), a prevenção das doenças bucais é o objetivo atual da odontologia direcionada para a promoção de saúde pois, apesar de não apresentarem riscos diretos à vida do indivíduo, as afecções que acometem o sistema estomatognático acabam por afetar sua qualidade de vida.

Sallum, Martins e Sallum (2004) consideram que as interferências periodontais devem se basear em evidências cientificas, dentro de uma visão de saúde geral. A avaliação periodontal não está mais centralizada apenas nos aspectos locais do periodonto, mas ampliou seus horizontes para o ser humano 
como um todo, absorvendo os conceitos da periodontia médica, as respostas do hospedeiro, suas condições sistêmicas e fatores de risco. Tais estudiosos citam que o diabetes, o hábito de fumar e a susceptibilidade genética, entre outros fatores, têm sido associados ao aumento da prevalência da doença periodontal.

Moraes, Dias e Furtado (2004) afirmam que as preocupações com a saúde geral transcendem os limites da área médica, sendo de conhecimento que um elevado número de doenças sistêmicas decorre do descontrole de predisponentes que escapam da atuação médica. Apontam também a importância da interação entre as ciências da saúde, usando como exemplo o estudo sobre o papel das doenças periodontais e dentárias de origem infecciosa no estabelecimento e/ou desenvolvimento dos problemas do aparelho circulatório, e recomendam a utilização de protocolos integrados de prevenção e tratamento multidisciplinar para o controle da doença periodontal e das moléstias cardiovasculares, com vistas à promoção da saúde geral dos pacientes de risco para ambas as condições. 


\section{PROPOSIÇÃO}

O presente trabalho teve como objetivos:

> investigar, na literatura especializada, a relação saúde e trabalho e levantar informações sobre a saúde bucal dos trabalhadores no contexto das empresas verificando, ao longo da história, as ações implementadas nesse sentido;

$>$ verificar a presença ou ausência, além do modus operandi, de Serviços Odontológicos em algumas empresas do Estado de São Paulo no ano de 2004, e como tais serviços são geridos;

$>$ discutir, à luz da literatura, aspectos de âmbito kgal quanto à participação do cirurgião-dentista na equipe multidisciplinar dos Serviços Especializados em Segurança e Medicina do Trabalho;

propor um programa de promoção de saúde bucal dirigido aos trabalhadores. 


\section{MATERIAL E MÉTODO}

A amostra estudada na presente investigação compreendeu 15 empresas de diversos setores localizadas no Estado de São Paulo. Para a obtenção de dados qualitativos em profundidade e quantitativos como base de comparação, o critério de escolha da amostra foi o não-probabilístico intencional. Nas empresas selecionadas, foram entrevistados seis gerentes de recursos humanos, seis cirurgiões-dentistas e três médicos.

O projeto de pesquisa, bem como o Termo de Consentimento Livre e Esclarecido e o relatório da entrevista, foram submetidos e aprovados pelo Comitê de Ética em Pesquisa da Faculdade de Odontologia da Universidade de São Paulo, conforme Parecer 20/04 (Anexo A).

A metodologia de pesquisa utilizada foi a revisão histórica da relação saúde bucal $\mathrm{x}$ trabalho e a análise de conteúdo da pesquisa de campo. A análise pelo método histórico consistiu na investigação de acontecimentos e processos em que a odontologia e sua relação com o trabalho estiveram presentes.

Para melhor atender à proposição deste trabalho, optou-se por adotar uma metodologia que permitisse obter uma base de dados qualitativos em profundidade para melhor discussão - e quantitativos - para ilustração dos temas propostos, como mencionado ao início deste capítulo.

O primeiro contato com as empresas foi realizado por telefone. Nesse contato, a autora forneceu a cada interlocutor informações sobre os objetivos e modus faciendi deste trabalho. As entrevistas foram agendadas pelas empresas. Nesse encontro foram novamente esclarecidos os objetivos da pesquisa, até a sua 
total compreensão pelo sujeito da pesquisa. Feito isso, procedeurse à leitura, juntamente com o entrevistado, do Termo de Consentimento Livre e Esclarecido (Apêndice A). Uma vez de acordo, o entrevistado assinava o termo, tomando posse de uma cópia do documento. Depois desses cuidados iniciava-se a entrevista propriamente dita (Apêndice B).

Os entrevistados são representados por letras do alfabeto (A, B, C, D...), ordenadas de acordo com o número de funcionários da empresa que representam, para facilitar a sua identificação e localização neste trabalho.

Anteriormente ao trabalho de campo, executou-se uma prova experimental da entrevista em duas empresas, para testar a entrevistadora, a sistemática da proposta, o tempo médio necessário para a entrevista e a reação da população. Após os ajustes deu-se início às entrevistas que, realizadas pela própria pesquisadora, foram gravadas em fitas K-7 - gravações estas previamente autorizadas pelos entrevistados -, e transcritas pela autora - com o auxílio de computador pessoal próprio -, e armazenadas em um banco de dados para futura análise do conteúdo. Inicialmente foram solicitadas informações para a identificação e a classificação da empresa, e a seguir foram abordados aspectos referentes aos serviços odontológicos oferecidos aos trabalhadores, à presença de cirurgiãodentista dentro da empresa - contratado ou conveniado -, quais as atividades que tal profissional exerce rotineiramente, se faz parte da equipe do Serviço Especializado de Segurança e Medicina do Trabalho e da Comissão Interna de Prevenção de Acidentes, e quais procedimentos de emergência odontológica são realizados durante a jornada de trabalho. Também foram formuladas perguntas sobre afastamentos por problemas de origem odontológica e sobre exames odontológicos 
ocupacionais e programas de promoção de saúde bucal. Os tópicos da entrevista constam do Apêndice B. 


\section{$5 \quad$ RESULTADOS E DISCUSSÃO}

\subsection{Caracterização da Amostra}

Como mencionado no capítulo anterior, a amostra deste estudo compreendeu 15 empresas de diversas áreas de atuação. Para as entrevistas, foram selecionados três tipos de profissionais - que poderiam responder às questões constantes do questionário de forma satisfatória: o médico do trabalho, o cirurgiãodentista da empresa e o responsável pelo Departamento de Recursos Humanos Depto. RH - (Figura 5.1).

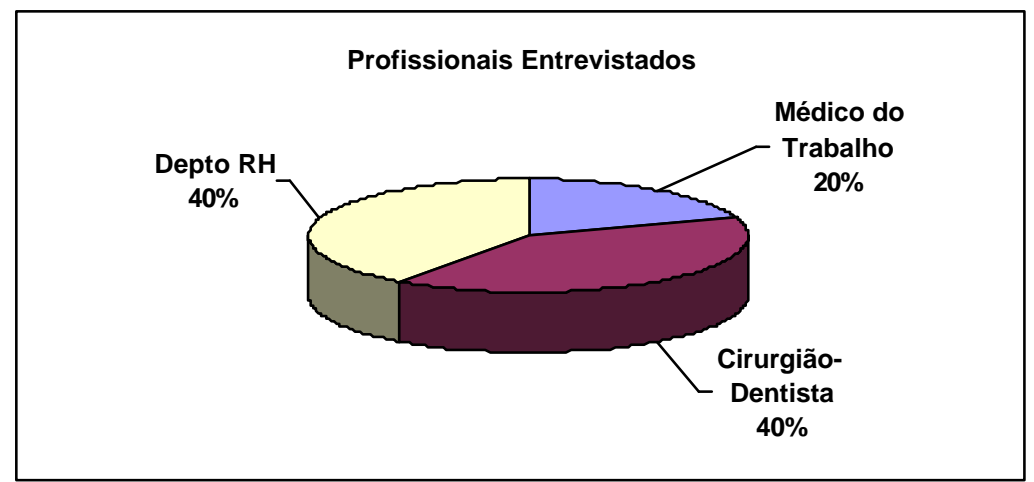

Figura 5.1 - Profissionais entrevistados (\%) nas 15 empresas investigadas

O Quadro 5.1 demonstra a classificação adotada pelo Cadastro Industrial do Centro das Indústrias do Estado de São Paulo (CIESP) em função do número de empregados de cada empresa. 


\begin{tabular}{|l|l|}
\hline Número de Empregados & Classificação da CIESP \\
\hline De 0 a 9 & Micro-empresa \\
De 10 a 99 & Pequena empresa \\
De 100 a 499 & Média empresa \\
De 500 e mais & Grande empresa \\
\hline
\end{tabular}

Quadro 5.1 - Classificação adotada pelo cadastro do Centro das Indústrias do Estado de São Paulo em função do número de empregados de cada empresa

Este estudo de casos contemplou empresas de pequeno, médio e grande portes (Figura 5.2), de diferentes ramos de atividades (Figura 5.3).

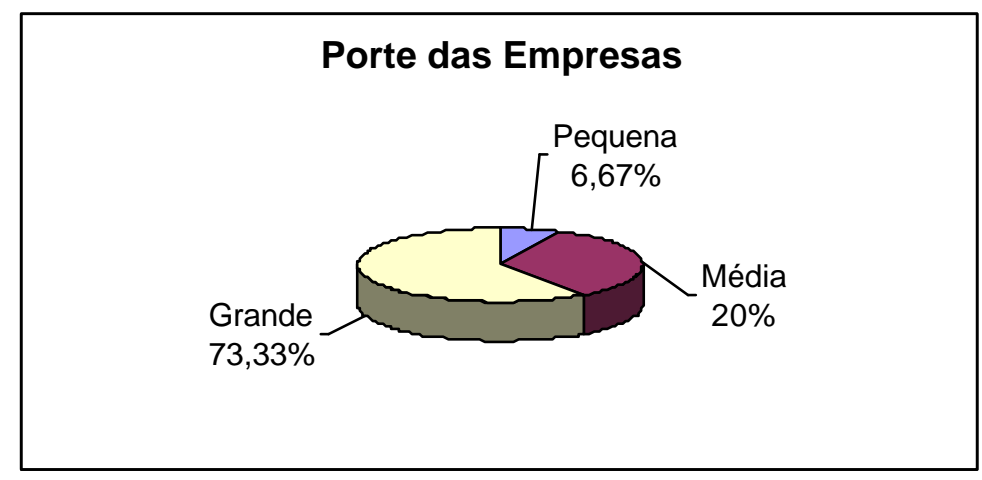

Figura 5.2 - Porte (\%) das 15 empresas investigadas

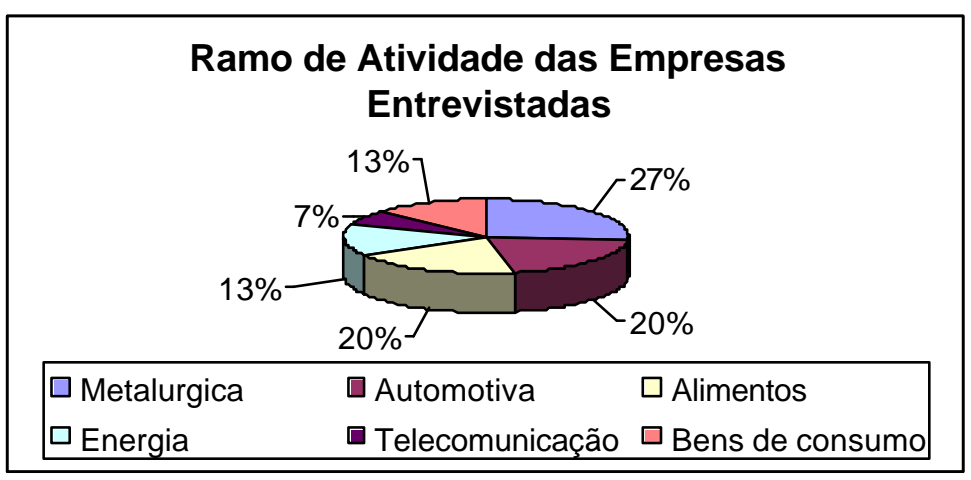

Figura 5.3 - Ramos de atividade (\%) das 15 empresas investigadas

As empresas foram classificadas por ordem decrescente de número de funcionários e identificadas por letras do alfabeto. Assim, a empresa A é aquela com 
maior número de empregados, e a empresa $\mathrm{O}$ é a que tem o menor número de empregados.

\section{EMPRESA A}

- Entrevistado: cirurgião-dentista

- Ramo de Atividade: energia

- Porte da Empresa: grande (35.000 funcionários)

- O cirurgião-dentista participa do SESMT? Sim

- O cirurgião-dentista participa da CIPA? Sim

- A empresa oferece algum tipo de serviço odontológico aos funcionários?

Assistencial (X) Ocupacional (X)

- São realizados exames odontológicos ocupacionais? Sim

- Há relato de sintomatologia de origem odontológica? Sim

- Há casos de afastamento por motivo odontológico? Sim

- Há serviço de emergência odontológica na própria empresa? Sim

- A empresa possui algum tipo de programa de promoção em saúde bucal? Sim

\section{EMPRESA B}

- Entrevistado: Depto. RH

- Ramo de Atividade: alimentos

- Porte da Empresa: grande (14.000 funcionários)

- O cirurgião-dentista participa do SESMT? Não

- O cirurgião-dentista participa da CIPA? Não

- A empresa oferece algum tipo de serviço odontológico aos funcionários? Assistencial (X) Ocupacional ( ) 
- São realizados exames odontológicos ocupacionais? Não

- Há relato de sintomatologia de origem odontológica? --

- Há casos de afastamento por motivo odontológico? Sim

- Há serviço de emergência odontológica na própria empresa? Não

- A empresa possui algum tipo de programa de promoção em saúde bucal? Não

\section{EMPRESA C}

- Entrevistado: cirurgião-dentista

- Ramo de Atividade: metalúrgica

- Porte da Empresa: grande (5.544 funcionários)

- O cirurgião-dentista participa do SESMT? Não

- O cirurgião-dentista participa da CIPA? Não

- A empresa oferece algum tipo de serviço odontológico aos funcionários? Assistencial (X) Ocupacional (X)

- São realizados exames odontológicos ocupacionais? Sim

- Há relato de sintomatologia de origem odontológica? Não

- Há casos de afastamento por motivo odontológico? Sim

- Há serviço de emergência odontológica na própria empresa? Sim

- A empresa possui algum tipo de programa de promoção em saúde bucal? Sim

\section{EMPRESA D}

- Entrevistado: médico do trabalho

- Ramo de Atividade: alimentos

- Porte da Empresa: grande (3.500 funcionários)

- O cirurgião-dentista participa do SESMT? Não 
- O cirurgião-dentista participa da CIPA? Não

- A empresa oferece algum tipo de serviço odontológico aos funcionários? Assistencial (X) Ocupacional ()

- São realizados exames odontológicos ocupacionais? Não

- Há relato de sintomatologia de origem odontológica? Sim

- Há casos de afastamento por motivo odontológico? Sim

- Há serviço de emergência odontológica na própria empresa? Não

- A empresa possui algum tipo de programa de promoção em saúde bucal? Sim

\section{EMPRESA E}

- Entrevistado: cirurgião-dentista

- Ramo de Atividade: energia

- Porte da Empresa: grande (3.300 funcionários)

- O cirurgião-dentista participa do SESMT? Sim

- O cirurgião-dentista participa da CIPA? Sim

- A empresa oferece algum tipo de serviço odontológico aos funcionários? Assistencial (X) Ocupacional (X)

- São realizados exames odontológicos ocupacionais? Sim

- Há relato de sintomatologia de origem odontológica: Sim

- Há casos de afastamento por motivo odontológico? Sim

- Há serviço de emergência odontológica na própria empresa? Não

- A empresa possui algum tipo de programa de promoção em saúde bucal? Sim 


\section{EMPRESA F}

- Entrevistado: cirurgião-dentista

- Ramo de Atividade: automotiva

- Porte da Empresa: grande (3.000 funcionários)

- O cirurgião-dentista participa do SESMT? Não

- O cirurgião-dentista participa da CIPA? Não

- A empresa oferece algum tipo de serviço odontológico aos funcionários? Assistencial (X) Ocupacional ()

- São realizados exames odontológicos ocupacionais? Não

- Há relato de sintomatologia de origem odontológica? Sim

- Há casos de afastamento por motivo odontológico? Sim

- Há serviço de emergência odontológica na própria empresa? Sim

- A empresa possui algum tipo de programa de promoção em saúde bucal? Sim

\section{EMPRESA G}

- Entrevistado: médico do trabalho

- Ramo de Atividade: automotiva

- Porte da Empresa: grande (1.900 funcionários)

- O cirurgião-dentista participa do SESMT? Não

- O cirurgião-dentista participa da CIPA? Sim

- A empresa oferece algum tipo de serviço odontológico aos funcionários? Assistencial (X) Ocupacional ()

- São realizados exames odontológicos ocupacionais? Sim

- Há relato de sintomatologia de origem odontológica? Sim

- Há casos de afastamento por motivo odontológico? Sim 
- Há serviço de emergência odontológica na própria empresa? Sim

- A empresa possui algum tipo de programa de promoção em saúde bucal? Sim

\section{EMPRESA H}

- Entrevistado: Depto. $\mathrm{RH}$

- Ramo de Atividade: automotiva

- Porte da Empresa: grande (1.500 funcionários)

- O cirurgião-dentista participa do SESMT? Não

- O cirurgião-dentista participa da CIPA? Não

- A empresa oferece algum tipo de serviço odontológico aos funcionários? Assistencial (X) Ocupacional ()

- São realizados exames odontológicos ocupacionais? Não

- Há relato de sintomatologia de origem odontológica? Não

- Há casos de afastamento por motivo odontológico? Sim

- Há serviço de emergência odontológica na própria empresa? Não

- A empresa possui algum tipo de programa de promoção em saúde bucal? Não

\section{EMPRESA I}

- Entrevistado: Depto. $\mathrm{RH}$

- Ramo de Atividade: telecomunicações

- Porte da Empresa: grande (1.060 funcionários)

- O cirurgião-dentista participa do SESMT? Não

- O cirurgião-dentista participa da CIPA? Não

- A empresa oferece algum tipo de serviço odontológico aos funcionários? Assistencial (X) Ocupacional () 
- São realizados exames odontológicos ocupacionais? Não

- Há relato de sintomatologia de origem odontológica? --

- Há casos de afastamento por motivo odontológico? Sim

- Há serviço de emergência odontológica na própria empresa? Não

- A empresa possui algum tipo de programa de promoção em saúde bucal? Não

\section{EMPRESA J}

- Entrevistado: cirurgião-dentista

- Ramo de Atividade: alimentos

- Porte da Empresa: grande (670 funcionários)

- O cirurgião-dentista participa do SESMT: Não

- O cirurgião-dentista participa da CIPA: Não

- A empresa oferece algum tipo de serviço odontológico aos funcionários? Assistencial (X) Ocupacional ()

- São realizados exames odontológicos ocupacionais? Não

- Há relato de sintomatologia de origem odontológica? Não

- Há casos de afastamento por motivo odontológico? Sim

- Há serviço de emergência odontológica na própria empresa? Sim

- A empresa possui algum tipo de programa de promoção em saúde bucal? Sim

\section{EMPRESAK}

- Entrevistado: Depto. $\mathrm{RH}$

- Ramo de Atividade: automotiva

- Porte da Empresa: grande (650 funcionários)

- O cirurgião-dentista participa do SESMT: Não 
- O cirurgião-dentista participa da CIPA: Não

- A empresa oferece algum tipo de serviço odontológico aos funcionários? Assistencial (X) Ocupacional ()

- São realizados exames odontológicos ocupacionais? Não

- Há relato de sintomatologia de origem odontológica:--

- Há casos de afastamento por motivo odontológico? Sim

- Há serviço de emergência odontológica na própria empresa? Não

- A empresa possui algum tipo de programa de promoção em saúde bucal? Não

\section{EMPRESA L}

- Entrevistado: cirurgião-dentista

- Ramo de Atividade: automotiva

- Porte da Empresa: médio (150 funcionários)

- O cirurgião-dentista participa do SESMT? Sim

- O cirurgião-dentista participa da CIPA? Não

- A empresa oferece algum tipo de serviço odontológico aos funcionários? Assistencial (X) Ocupacional ()

- São realizados exames odontológicos ocupacionais? Sim

- Há relato de sintomatologia de origem odontológica? Sim

- Há casos de afastamento por motivo odontológico? Sim

- Há serviço de emergência odontológica na própria empresa? Sim

- A empresa possui algum tipo de programa de promoção em saúde bucal? Sim 


\section{EMPRESA M}

- Entrevistado: Depto. $\mathrm{RH}$

- Ramo de Atividade: metalúrgica

- Porte da Empresa: médio (119 funcionários)

- O cirurgião-dentista participa do SESMT? Não

- O cirurgião-dentista participa da CIPA? Não

- A empresa oferece algum tipo de serviço odontológico aos funcionários? Assistencial ( ) Ocupacional ( )

- São realizados exames odontológicos ocupacionais? Não

- Há relato de sintomatologia de origem odontológica? --

- Há casos de afastamento por motivo odontológico? Não

- Há serviço de emergência odontológica na própria empresa? Não

- A empresa possui algum tipo de programa de promoção em saúde bucal? Não

\section{EMPRESA N}

- Entrevistado: médico do trabalho

- Ramo de Atividade: bens de consumo

- Porte da Empresa: médio (103 funcionários)

- O cirurgião-dentista participa do SESMT? Não

- O cirurgião-dentista participa da CIPA? Não

- A empresa oferece algum tipo de serviço odontológico aos funcionários? Assistencial ( ) Ocupacional ( )

- São realizados exames odontológicos ocupacionais? Não

- Há relato de sintomatologia de origem odontológica? Sim

- Há casos de afastamento por motivo odontológico? Sim 
- Há serviço de emergência odontológica na própria empresa? Não

- A empresa possui algum tipo de programa de promoção em saúde bucal? Não

\section{EMPRESA O}

- Entrevistado: Depto. RH

- Ramo de Atividade: bens de serviço

- Porte da Empresa: pequeno (37 funcionários)

- O cirurgião-dentista participa do SESMT? Não

- O cirurgião-dentista participa da CIPA? Não

- A empresa oferece algum tipo de serviço odontológico aos funcionários? Assistencial ( ) Ocupacional ( )

- São realizados exames odontológicos ocupacionais? Não

- Há relato de sintomatologia de origem odontológica:--

- Há casos de afastamento por motivo odontológico? Não

- Há serviço de emergência odontológica na própria empresa? Não

- A empresa possui algum tipo de programa de promoção em saúde bucal? Não

Os resultados obtidos nas entrevistas foram tratados quantitativa e qualitativamente e são apresentados e discutidos em tópicos específicos a seguir. 


\subsection{Participação do Cirurgião-Dentista no Serviço Especializado em Engenharia de Segurança e Medicina do Trabalho (SESMT)}

A Norma Regulamentadora № 4 da Portaria 3.214/78 (BRASIL, 1998b) não menciona a obrigatoriedade de participação do cirurgião-dentista na equipe do SESMT. De acordo com esse dispositivo legal, integram tal equipe somente o médico do trabalho, o engenheiro de segurança do trabalho, o enfermeiro do trabalho, o técnico de segurança do trabalho e o auxiliar de enfermagem. Entretanto, os resultados encontrados na presente investigação demonstram que, mesmo não sendo obrigatório por lei federal, $20 \%$ das empresas entrevistadas (Figura 4.4) incluem o profissional cirurgião-dentista na equipe multidisciplinar do SESMT, focando a saúde bucal de seus trabalhadores, de acordo com a recomendação feita por Guimarães e Rocha (1979b) e Vianna e Santana (2001).

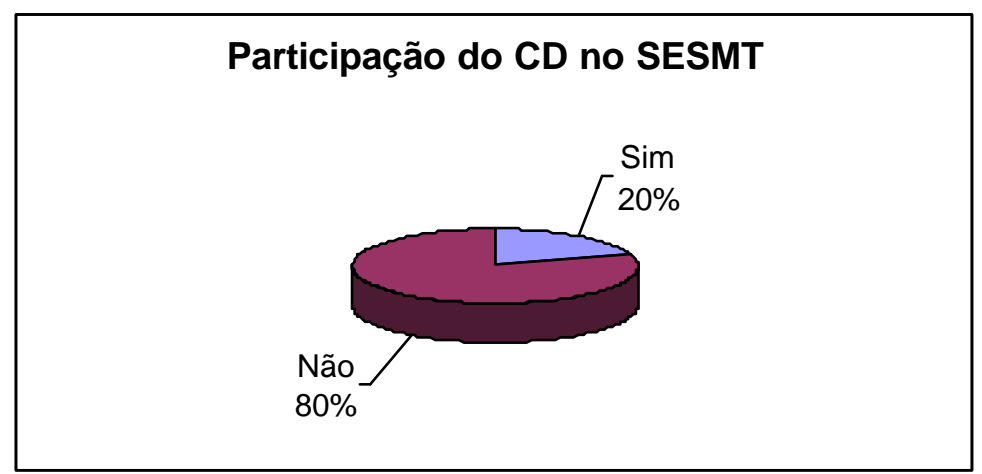

Figura 5.4 - Participação do CD no SESMT das empresas investigadas

Assim, com a regulamentação da nova especialidade - Odontologia do Trabalho -, mencionada no capítulo 2, abre-se um novo mercado de atuação para o cirurgião-dentista nas empresas.

A seguir, a título de ilustração, são apresentadas partes das entrevistas realizadas, nas quais os entrevistados comentam sobre o SESMT. 
EMPRESA A: Possui SESMT, e a equipe é constituída por médicos, enfermeiros, cirurgiões-dentistas e técnico de enfermagem, pessoal das áreas técnica e administrativa, e também psicólogo. O cirurgião-dentista participa ativamente das reuniões do SESMT. Nesse escritório a participação começou em 1987, quando eu entrei, mas na empresa a atividade ocupacional antecede essa data. Se você consultar a literatura, constatará que um dos primeiros trabalhos voltados ao assunto é desta empresa, isso por volta de 1980. A empresa já é bem antiga na área. Tem um serviço de saúde ocupacional localizado dentro de uma área que se chama Segurança, Meio Ambiente e Saúde (SMS), portanto há uma gestão de Segurança, Meio Ambiente e Saúde que cobra a evolução da empresa e que teve início há uns três anos aproximadamente. Anteriormente, as atividades de saúde ocupacional estavam afetas à área de recursos humanos, hoje não estão mais, então hoje existe uma integração muito maior entre a atividade ocupacional e as unidades de negócio da companhia. Você tem uma integração muito maior, por exemplo, entre a atividade de refinaria e a plataforma, por que nós estamos dentro de uma unidade organizacional na qual de você se relaciona com o aspecto de engenharia de segurança e os aspectos ambientais também. Saúde ocupacional é um assunto que, entre outros aspectos, emana muito do que se chama riscos ambientais. Então, nós evoluímos recentemente nesse sentido, era algo que a empresa buscava há muito tempo."

EMPRESA D: Sim, possui o SESMT, que é composto por médico do trabalho, engenheiro de segurança do trabalho, técnico de segurança do trabalho, auxiliares de enfermagem do trabalho. Além disso, essa equipe conta com fisioterapeuta, educador físico, um grupo de psicólogas e fonoaudiólogas, é uma equipe 
multidisciplinar. Infelizmente nós gostaríamos de ter o cirurgião-dentista, nós da área de saúde do SESMT, mas aí as empresas em geral não têm no momento. Seria até uma grande oportunidade, se o seu trabalho ajudasse, para que a nossa legislação do trabalho, ou melhor, dentre as normas regulamentadoras da CLT, uma que rege o serviço de saúde, que é a NR-7, deveria ter como obrigatoriedade, ou no mínimo de 100 funcionários, toda empresa tem a obrigatoriedade de ter um cirurgião-dentista, pelo menos num horário de 4 horas por dia, para fazer a prevenção oral. Não existindo essa obrigatoriedade, são poucas as empresas que têm, no corpo do SESMT, vamos dizer assim, o cirurgião-dentista com especialização em Odontologia Ocupacional, tendo em vista as condições de saúde bucal que a nossa população tem e o difícil acesso a essa área. Então é uma ou outra empresa que tem essa colocação. Nós não temos o cirurgião-dentista dentro da empresa, o que seria muito bem vindo, fazendo a parte ocupacional e preventiva.

EMPRESA E: "Sim, possui. É composto pela medicina do trabalho, enfermagem do trabalho e engenharia de segurança do trabalho, a odontologia do trabalho ainda não compõe o SESMT, porque a própria delegacia regional do trabalho não reconhece o cirurgião-dentista como um membro integrante do SESMT. Oficialmente não há a participação, extra-oficialmente eu participo de todas as atividades".

EMPRESA F: "Tem o SESMT, mas o cirurgião-dentista não participa pois é terceirizado, o médico pertence à empresa, aqui é um consultório particular que um cirurgião-dentista montou aqui, e a gente presta serviço atendendo os pacientes, mas é particular... O cirurgião-dentista não participa da área ligada ao trabalho a 
menos que seja solicitado, como por exemplo, quando ocorre algum acidente de trabalho, o funcionário passa por aqui”.

Empresa G: "A empresa possui o SESMT na própria empresa, e a equipe é composta pelo médico do trabalho, pelo engenheiro de segurança, por dois auxiliares de enfermagem do trabalho e por seis técnicos de segurança do trabalho. Tem dois cirurgiões-dentistas, pela manhã e à tarde, mas eles não fazem parte desta equipe, eles são terceirizados por uma entidade”.

EMPRESA L: "Sim, possui. Tem um médico do trabalho aqui e ele está mais ciente da coisa, mas desde o ano passado nós estamos interagindo. A empresa é bem ligada ao meio ambiente. O cirurgião-dentista participa das reuniões do SESMT desde que começou esse sistema, o consultório odontológico está aqui há 18 anos, eu estou aqui há 16 anos, no começo não tinha, nós não participávamos, mas de um ano para cá a participação é efetiva. Há algum tempo, uns cinco anos atrás, nós tínhamos meia participação, só em algumas coisas, aí chamavam a gente, mas não era aquela participação. Atualmente, nós estamos em todas as planilhas, tudo o que estiver decidido lá, mesmo que a gente não esteja presente por qualquer motivo, como eu trabalho aqui só meio período, de vez em quando tem alguma coisa e eu não estou, não dá para estar presente, mas eu sou chamado lá e sou informado do que foi feito".

Ainda de acordo a citada Norma Regulamentadora (BRASIL, 1998b), o médico do trabalho que integra o SESMT deve ser detentor de 
denominação equivalente, reconhecida pela Comissão Nacional de Residência Médica do Ministério da Educação, ambos ministrados por universidade ou faculdade que mantenha curso de graduação em medicina.

A especialidade Odontologia do Trabalho exige documento semelhante do cirurgião-dentista do trabalho, caso este venha a ser incluídos na legislação do trabalho vigente.

O excerto da entrevista da Empresa D, anteriormente apresentado, vem ao encontro daquilo que postulam a American Dental Association (1942), Brock (1958) e Petty (1943), quando mencionam a necessidade de especialização do profissional cirurgião-dentista que pretenda ingressar na área do trabalho:

O Conselho Federal de Medicina regulamentou, por meio da Resolução 1.488/98 (CFM, 1998), as atribuições específicas do médico que participa da equipe do SESMT, e que devem ser conhecidas e cumpridas por todos aqueles que prestam assistência médica a trabalhadores. Segundo o artigo 1ํ dessa Resolução, são atribuições dos profissionais que prestam assistência médica ao trabalhador:

- $\quad$ assistir ao trabalhador, elaborar seu prontuário médico e fazer todos os encaminhamentos devidos;

- $\quad$ fornecer atestados e pareceres para o afastamento do trabalho sempre que necessário, considerando que o repouso, o acesso a terapias ou o afastamento de determinados agentes agressivos faz parte do tratamento;

- fazer laudos, pareceres e relatórios dos exames médicos e dar encaminhamento, sempre que necessário, para benefício do paciente e dentro dos preceitos éticos, quanto aos dados de diagnóstico, prognóstico e tempo previsto de tratamento.

Também o CFO (2002), no art. $3^{\circ}$ da Resolução no 25, respalda a atividade do cirurgião-dentista do trabalho, estabelecendo as suas áreas de competência:

- identificação, avaliação e vigilância dos fatores ambientais que possam constituir risco à saúde bucal no local de trabalho, em qualquer das fases do processo de produção;

- assessoramento técnico e atenção em matéria de saúde, de segurança, de ergonomia e de higiene no trabalho, assim como em matéria de equipamentos de proteção individual, entendendo-se inserido na equipe interdisciplinar de saúde do trabalho operante; 
- $\quad$ planejamento e implantação de campanhas e programas de duração permanente para educação dos trabalhadores quanto a acidentes do trabalho, doenças ocupacionais e educação em saúde;

- organização estatística de morbidade e mortalidade com causa bucal e investigação de suas possíveis relações com as atividades laborais; e,

- realização de exames odontológicos para fins trabalhistas.

Como demonstrado na Figura 4.4, 80\% das empresas investigadas possuem Serviços Especializados de Engenharia de Segurança e Medicina do Trabalho conforme as normativas legais mas, por não ser exigido por lei, não referenciam o cirurgião-dentista no quadro de profissionais que o integram. Tais achados coincidem com o que indicam Midorikawa (2000) e Pizzatto (2002), que não observaram participação do cirurgião-dentista nos SESMTs das empresas pesquisadas.

\subsection{Participação do Cirurgião-Dentista na Comissão Interna de Prevenção de Acidentes}

A Comissão Interna Prevenção de Acidentes do Trabalho (NR-5) é composta por representantes dos funcionários, eleitos por seus pares, e por funcionários indicados pela diretoria da empresa, e o número de membros que a integram depende do número total de funcionários da empresa. O objetivo da CIPA é a prevenção de acidentes e doenças decorrentes do trabalho, de modo a compatibilizar permanentemente o trabalho, a preservação da vida e a promoção da saúde do trabalhador (BRASIL, 1998b).

Embora alguns autores recomendem a participação de cirurgiões-dentistas nas CIPAs (ARAUJO; GONINI JUNIOR, 1999; GUIMARÃES; ROCHA, 1979b; 
VIANNA; SANTANA, 2001) constatou-se, no presente estudo, que apenas $13,33 \%$ das empresas investigadas contam com a participação direta ou indireta desse profissional; as demais $(86,67 \%)$ não mantêm profissional da área nas CIPAs, embora 6,67\% delas compreendam a necessidade dessa participação.

A seguir, são apresentados excertos das entrevistas realizadas, nos quais os entrevistados tecem comentários sobre a participação do cirurgião-dentista nas CIPAs.

EMPRESA A: "Não como membro direto, porque na CIPA há um processo de eleição, ele pode participar se for eleito. A empresa normalmente determina o representante dela. O SESMT auxilia nas reuniões da CIPA e, se solicitado, o cirurgião-dentista auxilia em casos diretamente relacionados a ele. Não tenha dúvida, existe essa participação, inclusive em palestras voltadas à prevenção da saúde bucal, estabelecendo relações com a saúde sistêmica, pronto-socorro, essas coisas...."

EMPRESA C: "O cirurgião-dentista não participa por falta de tempo. A gente sabe da necessidade, é onde a gente tem os representantes da empresa que são votados pelos próprios funcionários, são os ĺderes de algumas áreas. Seria interessante manter essa interação, porque eles poderiam transmitir as informações. A empresa apoiaria a iniciativa se houvesse tempo disponível. As reuniões são quinzenais e, quando ocorre algum acidente de trabalho, eles se reúnem independente da data da reunião".

EMPRESA E: "Eu, como cirurgião-dentista do trabalho, sou membro efetivo da CIPA, nós chamamos de membro vitalício. A CIPA é composta praticamente pelos mesmos profissionais, são todos profissionais do SESMT". 
EMPRESA G: "A empresa possui CIPA, a regularidade das reuniões respeita as especificações da lei: há uma reunião ordinária a cada mês, e reuniões extraordinárias quando ocorre algum acidente. O cirurgião-dentista não participa dessas reuniões. Com certeza, se houver um acidente em que a cavidade bucal esteja envolvida, o cirurgião dentista será convocado, com certeza absoluta”.

É inegável a importância da participação do cirurgião-dentista do trabalho na CIPA. Como postulam Midorikawa (2000) e Silva e Souto (1983b), esse é um espaço privilegiado para a abordagem de todos os aspectos relacionados à saúde bucal no âmbito ocupacional, sejam eles relacionados aos acidentes de trabalho, sejam eles conseqüência de doenças profissionais que se manifestam na cavidade bucal.

\subsection{Serviços Odontológicos nas Empresas}

Embora no Brasil a regulamentação da especialidade Odontologia do Trabalho - cuja competência é direcionada aos cuidados com a saúde bucal dos trabalhadores (CFO, 2002) - seja recente (CFO, 2001), alguns estudos do início do século $X X$ já relatavam a existência de serviços odontológicos nas indústrias (DUNNING, 1942; PETTIBONI, 1923; WALLS; BETHLEM, 1942).

Das empresas investigadas, $80 \%$ possuem algum tipo de serviço odontológico - 33\% mantêm esse tipo de atividade dentro da própria empresa, e $25 \%$ já implantaram a Odontologia do Trabalho. Apenas $20 \%$ não fornecem serviços 
odontológicos aos funcionários, sob a alegação de que tais serviços aumentariam os custos da empresa, e pouco interesse despertariam nos funcionários.

Dentre as formas de gestão da assistência odontológica oferecida aos funcionários, foram encontradas: autogestão, reembolso, convênio interno - com consultório dentro da empresa - e externo - rede credenciada fora dos limites da empresa - e consultório particular na empresa.

A seguir, são apresentados trechos das entrevistas realizadas, nos quais os entrevistados comentam o oferecimento de serviços odontológicos pelas empresas.

EMPRESA B: "Não existe serviço odontológico dentro da empresa. A odontologia é vista como um benefício, porque se você não for ao cirurgião-dentista aquele ano, não receberá o dinheiro. Se você for, terá que trazer a nota fiscal com o valor do tratamento, e aí eles reembolsam até $R \$ 300,00$. É mais para que seja feita a manutenção da saúde bucal desse colaborador, mas também tem a Ortodontia: para quem usa aparelho a empresa paga metade do aparelho e metade da manutenção mensal. É uma coisa à parte, se o colaborador não usar aparelho ortodôntico, só recebe aquela verba anual para ir ao cirurgião-dentista. Já faz bastante tempo que se tem esse benefício, eu estou na empresa há 8 anos, e desde que entrei sempre foi o mesmo esquema... Eles estão com um projeto para convênio odontológico, mas por enquanto nós recebemos uma verba anual, para ir ao cirurgião-dentista, de $R \$ 300,00$ por pessoa e $R \$ 100,00$ para cada dependente: o colaborador pode escolher o cirurgião-dentista que quiser. $A$ empresa paga $R \$ 300,00$ reais por ano para os funcionários que fizerem algum tratamento odontológico." 
EMPRESA C: "Sim. São 4 consultórios completos, 8 cirurgiões-dentistas contratados, 2 auxiliares, sala de $R x$ e esterilização (autoclave e estufa), os consultórios funcionam 24 horas, em função dos turnos. Também há um convênio, mediante o qual os funcionários recebem um percentual dos custos decorrentes de tratamento da empresa, sendo necessárias perícia inicial e final para a aprovação do tratamento. No consultório da empresa são realizados exames admissionais, periódico, atendimento básico, preventivo, perícias e emergências. O atendimento assistencial é mais demorado e burocrático, e algumas normas devem ser cumpridas: o paciente deve ter passado pelo periódico para depois ser convocado: se for possível a realização do tratamento no consultório da empresa, ele será tratado, se necessitar de alguma especialidade, esta será indicado. O convênio é para funcionários e dependentes ( \pm 2000 funcionários no total). A Odontologia entrou na empresa há 8 anos, começou de forma única e exclusivamente assistencial e hoje se transformou em odontologia ocupacional. Os funcionários que têm acesso são os 5.544 efetivos. São oferecidos serviços assistencial, curativo, preventivo, educativo, emergencial, perícias e exames ocupacionais; o serviço assistencial contempla apenas o atendimento básico; se for necessária alguma especialidade, o funcionário é encaminhado a profissionais da rede credenciada do convênio."

EMPRESA D: "Sim, no plano médico de família, que é o plano para o pessoal operacional básico. É convênio terceirizado, não é dentro da empresa. Está implantado aproximadamente há 4 anos, e houve melhora considerável, tanto é que a opção para esse plano - aliás foi opcional a escolha desse plano - foi grande; e houve uma migração muito grande do plano básico - sem odontologia - para o plano família, que tinha o plano odontológico gratuito, então houve migração, e os 
funcionários que iam ingressando na empresa na área operacional já entravam com esse plano, que tem o atendimento odontológico. Os funcionários que êm esse benefício são os que têm o plano família, que é o plano básico mais os seus familiares. O pessoal administrativo não tem nenhum serviço odontológico, no momento não. O que é oferecido é o básico exigido pela NS. O funcionário não tem custo, a assistência é gratuita para essa pessoa que não tem condições financeiras para bancar o custo do tratamento odontológico. Obviamente, se houvesse trabalho de prevenção, uma boa alimentação, eles teriam facilidade para fazer a manutenção e para ir ao cirurgião-dentista, só que a condição odontológica chega a um ponto que acaba encarecendo o custo: você não faz manutenção e prevenção, e quando vai ao cirurgião-dentista acaba sendo mais caro, então por esse motivo, não o empregado, mas a família dele, a empresa ofereceu esse convênio, que atinge principalmente a família, porque o indivíduo passa sempre por um exame médico, então a tendência é o médico selecionar aqueles que estão em melhores condições para o trabalho: vai haver melhor alimentação dentro da empresa, vai entrar com uma melhor condição de saúde, só que os familiares dele, que dependem da remuneração dele, não vão ter essa condição, ou até bem pior que essa condição, de alimentação e de higiene oral.. O que vai acontecer? Esses indivíduos não vão ao cirurgião-dentista e a tendência é haver problemas na cavidade oral, quando não é caro o orçamento, e então o que acontece, a empresa oferecendo esse serviço, você dá atenção para essa família e depois fica só fazendo a manutenção, é mais prático. A empresa resolveu dar como benefício, que isso acresce e valoriza no aspecto remuneração, e estamos fazendo um bem social com isso. Ele não desembolsa nada, é gratuito. O que nós temos aqui é a odontologia no convênio e a assistência médica para o pessoal que está na parte de operação, que é o pessoal 
que tem o salário básico da empresa; eles têm a odontologia gratuita, mas nós não temos a odontologia para todos."

EMPRESA E: "Nós temos dois focos na parte odontológica. Um que é mais antigo e tradicional, que é o foco assistencial. Este é disponibilizado aos empregados e seus dependentes legais, através do que chamamos de plano odontológico. Este plano não é administrado pela empresa, é um plano administrado pela Fundação administradora dos planos de saúde, que recebe o dinheiro da companhia, administra isso e faz os devidos investimentos na área da saúde. Como funciona o plano odontológico na nossa empresa? $50 \%$ de cada procedimento é pago pelo empregado, e o restante é coberto pela empresa, isso dentro da tabela da própria Fundação. Evidentemente que os nossos empregados podem utilizar os recursos credenciados pela Fundação, e têm a possibilidade de utilizar recursos não credenciados, pelo sistema de reembolso. No caso de profissionais credenciados, 0 empregado paga diretamente o valor correspondente a $50 \%$ do tratamento e a Fundação, mediante a comprovação legal do tratamento realizado, depositará diretamente na conta bancária do profissional o valor restante. O empregado não é descontado em holerite, não tem nenhum tipo de ônus, a não ser aquilo que pagou para o profissional. No sistema de reembolso, o funcionário tem liberdade para escolher qualquer profissional da área; ele paga 100\% do valor do tratamento ao profissional, e apresenta o recibo do tratamento e uma ficha padronizada devidamente preenchida à Fundação, que analisará o que foi feito (coerência clínica) e, se não houver irregularidade, reembolsará ao funcionário $50 \%$ do valor previsto para o tipo de tratamento realizado na tabela da Fundação. 
Já mais recentemente, há uns 15 anos, existe um serviço exclusivamente voltado para a parte ocupacional. Nós fazemos o monitoramento das condições bucais do empregado, o aconselhamento ou promoção, como nós chamamos, porque a promoção da saúde bucal dentro da empresa é mais ampla do que um simples aconselhamento ao empregado, de vez que implica um conjunto de ações que vão desde a orientação bem personalizada para o empregado na hora do exame propriamente dito - que se desdobra em levantamento epidemiológico, confecção e elaboração de relatórios estatísticos dentro da empresa - até as ações didáticoinformativas dentro da empresa. Todas essas ações são feitas seguindo um modelo pedagógico, fundamentado nas necessidades de cada área da nossa empresa, até para que a gente não trate de forma igual os desiguais, porque se não a gente começa a não ter a repercussão, o resultado que gostaria, que é um dia chegar a ter a saúde bucal de uma forma equalizada dentro da empresa, desde o empregado operacional até o empregado de função gratificada. Todos devem ter o mesmo tipo de informação, independentemente do nível de escolaridade. Por essa razão nós temos um modelo pedagógico voltado a cada segmento da empresa, inclusive com linguagem adequada para isso, para atingir os vários níveis com o mesmo conteúdo informativo. Evidentemente que essa área está preparada para os atendimentos chamados emergenciais, essa é uma outra separação que a empresa faz, pois o que é uma emergência? Um caso de acidente, que faz com que o empregado necessite de atendimento pois foi atingida uma estrutura estomatológica. Em tais situações é necessário fazer uma intervenção rápida para dar continuidade depois, em outro serviço, ao tratamento ou reabilitação desse empregado. Já uma dor de dente não é uma emergência para nós. Pode ser uma urgência para o empregado, porque está doendo, evidentemente há um desconforto, mas como nós sabemos que a grande 
maioria das doenças bucodentais é de progressão crônica, lenta e gradual, optamos por fazer primeiro a promoção, incentivar o empregado a cuidar antes que ocorra a urgência para ele, por isso nós não misturamos esses dois focos do trabalho."

EMPRESA F: "Temos. É um consultório particular, a empresa cede a sala, não cobra aluguel, luz, telefone, água, nada. São duas salas, aqui e lá em cima, tem dois consultórios, para facilitar para os pacientes, para que eles não tenham que ir para fora, deixar o posto de trabalho para sair e procurar por serviço odontológico, já está aqui dentro da empresa, é para todos os funcionários: do presidente ao faxineiro. todos têm acesso a esse serviço. O serviço está em funcionamento há aproximadamente trinta anos. São oferecidas todas as especialidades, como prótese, periodontia, endodontia, implante, clinica geral, só não tem ortodontia, o resto tem tudo. Tem quase 3 mil funcionários aqui, e muitos não sabem que tem consultório odontológico dentro da empresa. E muitos não dão valor à saúde bucal, seria uma maneira de divulgar estas informações. Portanto, são duas salas com $R X$, trabalham quatro cirurgiões-dentistas, cada qual em sua especialidade: um em prótese e implante, o segundo é endodontista, a terceira em implante e clínica geral, e o último oferece prótese e clínica geral. Segundo a carga horária, das 8h30 às 16h30, um dia por semana. A anamnese é geral, não foca na parte ocupacional, pois a secretária já conhece e sabe qual a área do paciente. Quanto à manutenção periódica, o pessoal é chamado para o retorno em intervalos de um ou dois anos, alguns vêm. O paciente paga para clínicos particulares, e a gente tem um convênio odontológico dos executivos - rede credenciada -, mas este é em consultório particular." 
EMPRESA G: "Sim, no ambulatório temos um gabinete dentário que atende das 7h00 às $16 h 00$, então há um trabalho em caso de urgência e um trabalho preventivo, um trabalho de rotina, quer dizer, nós temos os 1.900 funcionários que são atendidos nesse esquema. A espera para um atendimento de rotina varia em torno de três meses. Há um consultório, com dois cirurgiões-dentistas. Todos os funcionários têm acesso a esse serviço, que não é extensivo aos familiares. Um grupo de aproximadamente 80 executivos, gerentes executivos e diretores, eles têm um outro plano, que oferece a eles e seus dependentes uma rede de atendimento, e podem escolher o cirurgião-dentista que Ihes apetecer. O orçamento dos tratamentos passa pela auditoria da empresa prestadora do serviço, e é feito um reembolso de acordo com as tabelas da empresa; se o cirurgião-dentista for da empresa, será coberto sem grandes problemas. Hoje o atendimento dos funcionários é feito aqui, e totalmente custeado pela empresa, então eu pago para essa empresa terceira por manter um profissional aqui nesse horário, por manter todo o material fixo e o material de uso de rotina."

EMPRESA H: "Hoje, nem na nossa cobertura de assistência médica existe assistência odontológica a não ser emergência, que é aquele caso extremo: você está passando mal, pode estar passando mal, então vai ao pronto-socorro, que Ihe dará uma assistência, encaminhará. Na nossa planta de Araraquara hoje existe sim, mas existe um serviço contratado com essas empresas prestadoras de serviços odontológicos, então tem esse serviço e o custo é $100 \%$ do funcionário, por livre adesão, e o funcionário pode optar ou não, mas em São Bernardo ainda não foi implantado. Na verdade, há dois anos a gente vem discutindo isso e sempre passa para a pauta do ano que vem, porque antes tem que fazer um trabalho, não dá para 
simplesmente contratar uma empresa prestadora. Em uma pesquisa feita com algumas empresas que têm odontologia, levantou-se também que algumas empresas prestadoras de serviço, essas grandes empresas que administram, elas eventualmente oferecem um bom serviço, mas em alguns momentos você tem um ou outro credenciado a essas empresas que não responde ao que foi solicitado, então a gente fica imaginando o seguinte: se a intenção é colocar a odontologia, é melhor fazer um mapeamento geral do problema da empresa, fazer um serviço de prevenção, como já foi oferecido... Está em pauta para o ano que vem colocar uma empresa que forneça toda a orientação bucal, se é assim que se pode chamar; então essa empresa faz toda a análise do funcionário, orienta-o, mas não tem nenhum vínculo com prestadora de serviços. A partir daí, passa-se a começar a entender o que as empresas de assistência têm a oferecer, quais os profissionais, o tipo de material utilizado. Existe uma preocupação com relação a isso, por esse motivo até hoje ainda não se fez nada voltado, nem por livre adesão... Diferentemente de Araraquara, que tem um público menor, a coisa consegue ser mais local, em São Paulo a gente tem um leque grande. Ter um profissional interno na empresa nunca foi cogitado, há dois anos foi levantado o tema em planejamento do departamento, mas como existiam outras prioridades na frente... A empresa precisava sim de uma visão odontológica, mas precisa também melhorar a assistência médica, precisa fazer algo com relação a algumas coisas, então a gente nunca pensou. A hipótese de ter montado um consultório interno nunca foi levantada, porque primeiro seria necessário ter demanda, eu acho que até demanda a gente não teria problema, porque são 1.000 pessoas revezando em turno, espaço físico, é algo que a gente não tem hoje. Para a empresa, colocar uma estrutura odontológica não é interessante, isso nós podemos falar em termos de investimento, 
seria de repente até manter um profissional fora, vinculado diretamente para manter isso."

EMPRESA I: "A gente tem assistência odontológica, com um convênio. Essa assistência faz parte do pacote de benefícios flexíveis que a empresa tem ... Ela dá uma quantidade ' $X$ ' de benefícios para os funcionários, normalmente nesse pacote tem assistência médica, seguro de vida, vale-refeição, basicamente. O beneficio flexível é um pacote de vários benefícios, a gente tem 15 no total, e todos esses benefícios são oferecidos para todos os cargos; exceto carro, todos os outros são oferecidos para todos os funcionários, todo mundo pode escolher. Cada funcionário tem uma quantidade de pontos, então ele escolhe... Com esses pontos - cada beneficio também tem a sua pontuação -, o funcionário escolhe, com a quantidade de pontos que ele tem, quais os benefícios que vão fazer parte da cesta de benefícios dele. A assistência odontológica faz parte desse pacote de benefícios, e quem tiver interesse opta por ela. Ela é bastante procurada: no primeiro ano, que foi 2002, houve a adesão de 630 funcionários, e em 2003 esse número subiu para 719; isso quer dizer que agradou, mesmo havendo muitas dúvidas e apesar da burocracia, criou-se uma imagem de confiabilidade no programa e na própria empresa prestadora do serviço, então a procura aumentou. Fora os dependentes, o convênio tem vários planos e faz todo tipo de atendimento, ela tem todo tipo de especialista e procura ter todas as especialidades em cada região. Tem o plano que é bem mais básico, que é o tratamento de cáries e a limpeza simples, depois você vai subindo de plano, chegando a ter incluído o procedimento protético. O que diferencia, por exemplo: eu sou um funcionário, eu quero o plano odontológico na minha cesta de benefícios e eu vou escolher qualquer plano que eu quiser. Do 
mesmo jeito que eu tenho 15 benefícios e eu posso pegar os meus pontos e colocar do jeito que eu quiser, pode ser oferecida alguma variedade daquele beneficio, então na assistência odontológica eu ofereço quatro planos, que o funcionário escolhe, eu vou investir mais pontos na assistência odontológica, então eu vou entrar numa assistência odontológica que, além de todo o tratamento básico (só na rede credenciada), cubra a manutenção ortodôntica; já o segundo plano tem, além das coisas que estão na opção 1, a opção de reembolso também; o plano 3 é igual ao primeiro, só na rede credenciada, mas inclui prótese; e o plano 4 tem tudo: rede credenciada, reembolso (livre-escolha do profissional), prótese e manutenção ortodôntica. Esse benefício começou em outubro de 2002, antes disso não havia assistência odontológica. Todos os funcionários têm acesso. Cada um escolhe o que for importante para ele."

EMPRESA J: "Sim, possui serviço assistencial odontológico terceirizado. Eu não sou funcionária desta empresa. Aqui a gente faz todos os procedimentos, menos prótese e ortodontia. Então os básicos, como restauração, limpeza, cirurgia, canal, isso pode ser feito aqui dentro. É descontado em folha, portanto o plano odontológico é opcional, o funcionário, opta ou não pelo plano. Tendo o convênio, o funcionário é descontado em folha, não tem que mexer com dinheiro quando ele passa aqui em consulta, podendo procurar pela rede credenciada se mais adequado. Tem os procedimentos que podem ser feitos, já estabelecidos. Como prótese e ortodontia não são praticadas, então o paciente, tendo a carteirinha e estando credenciado, vem aqui, marca a consulta e é atendido normalmente. Ele sai durante o expediente, trata e volta para o trabalho. A empresa custeia uma parte (60\%), e o funcionário arca com o restante (40\%). O benefício existe há mais ou menos seis anos, e foi 
sempre o mesmo esquema de cirurgiões-dentistas credenciados de empresas de convênios. O funcionário marca a consulta e pode eventualmente faltar, mas o tratamento é imprescindível para ele. E tem o retorno, de seis em seis meses, que agendamos. Implantes também não são feitos. É uma sala só, o cirurgião-dentista fica das $8 h 00$ às $12 h 00$ de segunda a sexta-feira: tem uma cadeira, um $R X$, autoclave, armários com duas pias. Eu sou clínico geral. A anamnese é bem básica, não se atendo muito à função, o que faz ou não faz, realmente a gente não pergunta."

EMPRESA K: “Nós temos um convênio odontológico, empresa terceirizada. É uma rede credenciada, não tem consultório na empresa; o usuário tem direito à livre escolha do profissional, ele tem um livro em mãos e escolhe o que lhe convier. Ele tem planos, atualmente ele é custeado pelo empregado, a empresa não tem participação no custo, pelo menos por enquanto, mas são três planos - o último plano inclui tudo, inclusive prótese -, e vai de acordo com o valor de cada um, o funcionário escolhe o que lhe convier. A empresa fez o contrato, ela assume o pagamento, mas não é $100 \%$ adesão, o funcionário que quiser tem o custo e adere ao plano, descontando em folha. Desde novembro de 2003 nós temos este convênio, a cada mês a adesão aumenta, porque é assim, um funcionário tem e vai passando a informação para o outro colega de trabalho, e a cada mês o número de funcionários que desejam participar do plano está aumentando.”

EMPRESA L: "Possui serviço odontológico, mas por convênio. O convênio tem um contrato de prestação de serviços com a empresa. Todos os funcionários têm acesso, e o atendimento se estende aos dependentes. Além do consultório interno 
(dentro da empresa), há uma rede credenciada próxima da região. Aqui na empresa eles oferecem gratuitamente cirurgia (não incluídas extrações comuns), dentística (amálgama gratuito), endodontia, profilaxia, $R X$ etc. Há uma tabela com 34 itens que são gratuitos, estão cobertos. Há também itens que não são gratuitos, como serviços protéticos e ortodônticos (só na rede credenciada). O serviço protético, assim como a resina fotopolimerizável, não são cobertos, e são descontados na folha de pagamento do funcionário. Dependendo do volume, se for muita coisa, é dividido, mas sempre descontado em folha. Os dependentes são atendidos somente pela rede credenciada; os mesmos itens que são cobertos para o funcionário aqui, são cobertos para os dependentes na rede. Quando o atendimento odontológico começou aqui, eram dois cirurgiões-dentistas que trabalhavam em período integral, das 9 h00 às 18h00. Eu trabalhava dois dias por semana, e o outro trabalhava três dias, mas houve uma reformulação muito grande, tinha 700 funcionários e teve um corte, viu-se que não seria mais necessário dois profissionais. Então fiquei somente eu, que sou clinico geral e deveria vir todos os dias meio período, mas como os funcionários trabalham em dois turnos, eu trabalho na segunda, quarta e sexta das 8 h00 às 11h00, e terça e quinta das 13 h30 às 17h30. Bom, antes da reforma, tudo o que tinha aqui era do convênio: armário, equipo, $R X$, material de limpeza... Depois da reforma, tudo é da empresa, só o equipo e o material de consumo não, são do convênio O consultório (espaço físico), os armários, água, luz, material de limpeza, descarpark, é tudo da empresa, só mesmo a parte odontológica é do convênio."

EMPRESA N: "Por enquanto não, a idéia da empresa é essa, mas nós estamos naquela fase de levantamento de custos, devido à crise do país nós estamos 
providenciando isso dessa maneira, é uma política nossa que vamos fazer futuramente."

EMPRESA O: "Não possui serviço odontológico. Antigamente a empresa tinha, mas era terceirizado. Foi no ano de 2002 para 2003, e a maioria dos funcionários desistiu desse serviço. Era um convênio odontológico e o funcionário tinha direito de participação no sistema. Todos os funcionários tinham acesso, bastava o interesse. O custo era bem baixo, 10 reais por funcionário, o serviço era só manutenção, o básico. A duração foi de um ano e os funcionários desistiram, porque a rede credenciada era fora de mão, longe da empresa, além de que acontecia de se marcar a consulta e o consultório ligava desmarcando dois dias antes, para remarcar consulta, ou então, deveria ter atendimento aos sábados e depois não teve, o funcionário ficou sem o horário, então era meio contramão."

A maioria dos estudiosos defende a manutenção de serviços odontológicos pelas empresas, pois a melhora do bem-estar físico, mental e social dos trabalhadores implica um significativo aumento do estímulo e da satisfação laboral, com conseqüente redução do absenteísmo e aumento de produtividade (DUNNING, 1942; FERREIRA, 1995; GUIMARÃES; ROCHA, 1979a, b, c; MARANO, 1989; MAZZILLI, 2003; THOMAS, 1943).

Além disso, como postulam Araujo e Gonini Junior (1999), é de extrema importância prevenir os efeitos nocivos das condições de trabalho e suas influências sobre a saúde, sendo que a prevenção deve sempre se antecipar à ocorrência dos agravos, definida a partir do mapeamento de riscos do trabalho; conscientizar o trabalhador sobre a importância da preservação da saúde bucal, fator significante da 
saúde geral; diagnosticar precocemente enfermidades especificas ou sistêmicas com manifestações bucais correlacionadas ao ambiente de trabalho; contribuir com as demais áreas profissionais da saúde e segurança do trabalho, em todas as ações que visem preservar a integridade do trabalhador.

\subsection{Exames Odontológicos Ocupacionais}

De acordo com a NR-7, o Programa de Controle Médico de Saúde Ocupacional tem como objetivos a "prevenção, rastreamento e diagnóstico precoce dos agravos à saúde relacionados ao trabalho, inclusive de natureza subclínica, além da constatação da existência de casos de doenças profissionais ou de danos irreversíveis a saúde dos trabalhadores" (BRASIL,1998b). Com base nesse entendimento, os exames odontológicos efetivamente integram o PCMSO, devendo ser realizados de forma complementar.

Os exames médicos ocupacionais, segundo Possibom (2001), devem obedecer aos prazos e à periodicidade previstos abaixo, que podem ser também aplicados aos exames odontológicos:

- admissional: antes que o trabalhador assuma as suas atividades;

- periódico: de acordo com os intervalos mínimos de tempo, conforme a faixa etária, o tipo de exposição e as peculiaridades das condições de trabalho;

- de retorno ao trabalho: obrigatoriamente no primeiro dia de volta ao trabalho de trabalhador ausente por período igual ou superior a 30 (trinta) dias por motivo de doença ou acidente de natureza ocupacional ou não, ou parto; 
- de mudança de função: obrigatoriamente antes da data da mudança;

- demissional: obrigatoriamente antes da data de homologação, desde que o ultimo exame médico ocupacional tenha sido realizado há mais de:

$\diamond 135$ (cento e trinta e cinco) dias para as empresas graus de risco 1 e 2 segundo o Quadro I da NR-4;

$\diamond 90$ (noventa) dias para as empresas graus de risco 3 e 4 segundo o Quadro I da NR-4.

Os trechos a seguir apresentados trazem comentários dos entrevistados acerca da conduta adotada pela empresa na qual atuam com relação à realização de exames odontológicos ocupacionais.

EMPRESA A: "Nós fazemos exames admissional, periódico, exames especiais (tipo retorno ao trabalho, antes de viajar para o exterior, o empregado é obrigado a fazer uma avaliação, até mesmo para não ter problemas lá). Na verdade não é um encargo, é um benefício, uma precaução. Se o empregado for viajar para áreas endêmicas, por exemplo, se alguém vai trabalhar lá na Amazônia, tem que ser avaliado antes. Muita gente fala: 'Não tem nada a ver com a odontologia', mas a gente faz junto com a área médica. E por que não envolve a odontologia, quem é que sabe quais são os limites e as repercussões, mesmo na área médica? Quando você entra na selva amazônica, e quebra o equilíbrio ecológico com a sua presença, você está sujeito as zoonoses que sequer são conhecidas, então nós fazemos uma avaliação, sim. Esses exames não são obrigatórios por lei federal, mas para a empresa são. A lei obriga alguma coisa na área odontológica, existe uma NR que estabelece a obrigatoriedade de alguns requisitos para a admissão na área marítima. Eu não tenho o número dela aqui, mas tem. Inclusive ela é muito curiosa, 
quer dizer, o sujeito tem que ter no mínimo sete dentes. Portanto existe uma Nr que aborda o trabalhador marítimo, e trabalhador marítimo não é só aquele que conceitualmente trabalha no mar, mas em águas fluviais internas também, e que estabelece uma obrigatoriedade, sim, se o sujeito tem que ter no mínimo sete dentes para ser admitido, você tem que examiná-lo. Eu coloco muito em discussão essa questão da obrigatoriedade, eu não sei se do ponto de vista legal, se fosse ter uma discussão para valer, se não é obrigado, por que as pessoas não podem tirar o terço médio inferior da face para trabalhar? Ninguém arranca fora metade da cabeça para poder trabalhar, e se nós pegarmos alguém que agora só vai trabalhar com joelho, agora não é mais o médico que faz, é o joelhólogo, então o joelho deixa de ser obrigatório... O que existe são questões que as pessoas discutem e que eu não sei se, em uma discussão jurídica para valer, realmente isso seria ou não necessário, porque a NR manda o que? Que você avalie o estado de saúde do indivíduo, a palavra médica é que deu essa distorção, como se as partes médica e odontológica fossem áreas distintas. Na verdade nós estamos no escopo, o objetivo não é discutir o que o médico faz quando alguém admitir, é discutir o que se faz em termos de saúde quando se admite essa pessoa. E houve essa distorção, também por cooperativismo médico, falta de mobilidade da classe odontológica, mas eu não sei não, se em uma briga para valer, a gente não consegue, juridicamente, mostrar que o texto da portaria não exclui a obrigatoriedade odontológica. Se você pode ter um acidente trabalhista com reflexos na face, atingindo a área odontológica, significa que existiu o acidente do trabalho, não? Então são coisas que a gente tem que levar para a frente, e a sua dissertação seguramente vai reforçar a nossa posição. Nos exames ocupacionais periódicos, podemos encontrar lesões pré-cancerígenas, lesões que não são cancerígenas, avaliação de tecidos mole, duros, e uma 
radiografia panorâmica. Eu já peguei casos com cisto dentígero avançadíssimo em ângulo de mandíbula: o sujeito trabalha em uma plataforma, cai e bate o queixo, vai ter uma fratura cominutiva de ângulo, que vai se transformar em um problema trabalhista... Ele simplesmente foi se tratar, resolveu o problema dele e foi admitido sem problemas, certo, então a gente avalia sim, há a avaliação para diagnóstico precoce e registramos. A conduta é a seguinte: se encontrar qualquer lesão com característica pré-cancerígena em uma pessoa que vai ser admitida - é claro que se alguém tem um fibroma ou algo que tenha a cara clínica de um fibroma eu não vou nem me preocupar com a admissão dele, ele vai ser admitido com a orientação de que procure alguém para resolver, porque aquilo vai ficar sendo irritado, a conduta clínica é esta -, nós fazemos esta abordagem: tórus mandibular, a gente registra, o exame periódico avalia, você sabe que em algumas situações o tórus mandibular vai crescendo tanto que vai ocupando o lugar da língua e você tem que tirar, fazemos a orientação; alterações de palato em fumantes, não-fumantes e eventualmente em pessoas com hábitos etílicos pouco recomendados, quer dizer que você encaminha para o tratamento, que você tem que fazer uma raspagem do palato e tudo o mais. Eu nunca tive o azar de pegar uma lesão cancerígena, mas eu já peguei uma lesão pré-cancerígena, basocelular, é maligna mas clinicamente não, agora um carcinoma espinocelular, que é o que mais me deixa preocupado, felizmente não... Lesões brancas em profusão, você tem uma grande quantidade de líquen plano, a gente acompanha, já peguei muita lesão branca assim, algumas até com a 'carinha' assim meio suspeita de neoplasia, e a gente geralmente manda para biópsia, se possível excisional. Eu já peguei mucocele, isso é comum, muito freqüente, como os papilomas. Quanto às manifestações bucais de doenças sistêmicas, como sífilis, nós temos inimigos mais poderosos no momento; não que a gente nunca tenha tido caso 
de sífilis, mas com manifestação bucal não, gonorréia também não. Já por exemplo pessoas com candidíase bucal, e que eram soropositivas para o HIV, mas cujo diagnóstico já estava feito, foi só uma questão orientação da pessoa, mas poderia ter sido diagnosticado, eu já peguei caso, já fiz diagnóstico inicial de AIDS em paciente meu, na empresa não... Infelizmente, um paciente meu veio a falecer e estava com candidíase, mas nunca houve um desses casos cujo diagnóstico inicial tenha sido estabelecido pelo cirurgião-dentista, mas poderia perfeitamente ter sido diagnosticado primeiro por nós. O que nós pegamos aqui que foi muito interessante, foi uma pessoa que posteriormente teve que fazer transplante renal, porque ele tinha uma sintomatologia dentária a restaurações incompatível com a realidade, um sangramento periodontal muito sério, e na ocasião nós discutimos isso com o médico; foi providenciada uma investigação mais aprofundada das alterações de pressão e ele continua vivo; faz mais de vinte anos, mas teve que fazer transplante renal; isso provavelmente teria sido constatado no exame médio periódico, mas a discussão surgiu inclusive a partir de uma avaliação odontológica que começou a despertar a atenção: por que o tratamento dava essa sintomatologia? Inclusive, eu nem encontrei grandes referências na literatura a respeito, mas a verdade é que alterações de pressão talvez colaborem com alterações pulpares, tenhamos ou não uma relação causal direta... o fato é que acertamos. Ele não teria passado pelo médico porque aqui o exame é muito rigoroso."

EMPRESA C: "Existe o exame admissional e o periódico, os demais não, pois como nenhum é obrigatório por lei federal, só é feito o que a empresa julga mais importante. Pelo regulamento interno da empresa, o exame admissional é obrigatório para todos os funcionários, mas não elimina o candidato à vaga. Esse exame gera 
um peso, que será somado aos pesos de outros exames - audição, visão, fisioterapia -, e o final é a avaliação médica, que leva em consideração todas as anteriores. O exame periódico é obrigatório também, o empregado não é obrigado a tratar aqui, mas é obrigado a passar pelo levantamento de dados, se ele faltar no exame odontológico, entra como falta no sistema e ele vai ser cobrado na gerência dele. Os dados são armazenados por 20 anos. No exame periódico é realizada uma manutenção periódica, com limpeza e raspagem periodontal, e uma reavaliação odontológica do empregado. Nenhuma sintomatologia bucal constante foi relatada pelos funcionários. Apenas quatro de uma mesma superintendência, mas de gerências diferentes, apareceram com escurecimento (tipo tetraciclina) de canino a canino superior, e na mesma superintendência foi relatado o único caso de câncer bucal com óbito do funcionário. Não é realizada uma anamnese investigativa. Todas as lesões bucais são controladas com arquivo de biópsia/diagnóstico/hipótese de diagnóstico."

EMPRESA D: "O que é feito é uma avaliação superficial, uma triagem pelo médico do trabalho. No exame de admissão ele dá uma olhada na arcada dentária, vê, faz uma avaliação clínica e não odontológica, não odontológica clínica pois não somos especialistas, a gente só faz uma avaliação clínica, visual, aparente, basicamente a gente vê a parte estética, lesões, só isso. Essa avaliação, que é uma avaliação simples, por nós não sermos especialistas na área, é registrada na ficha de exame médico de admissão por vinte anos após o desligamento do empregado; se ele trabalhar em alguma área de risco, seguindo a mesma legislação, a NR-7, fica por trinta anos armazenada. É realizado o exame médico periódico - a gente segue a norma regulamentar 7 - anualmente ou, de acordo com o risco, semestralmente ou 
bianualmente de acordo com o risco e com a idade. O mais freqüente na saúde bucal é a halitose; quando há dor de dente a gente não tem muito que fazer, a não ser encaminhar para o cirurgião-dentista, isso também é freqüente, e as outras estão relacionadas à saúde clinica, seriam da área médica: dores osteomusculoligamentares, mais freqüentes, relacionadas à musculatura, à postura, ou ao tipo de atividade, ligada a articulação são as queixas mais freqüentes, seguidas pelas doenças mais comuns: resfriado, gripe, eventualmente pneumonia, broncopneumonia, inflamações de orofaringe."

EMPRESA E: "Nós temos um modelo sacramentado da própria medicina do trabalho, e trabalhamos com os seguintes procedimentos: exame admissional, que não é de forma nenhuma seletivo, mas como segue o modelo admissional, e o empregado está dentro do modelo da CLT - o modelo dos 90 dias de experiência -, tudo aquilo que tem um impacto maior e que pode gerar algum tipo de conseqüência, tanto sistêmica como relacionada à segurança, o empregado é orientado e monitorado para que a solução dessas complicações ocorra dentro dos 90 dias, até para a empresa aproveitar o empenho do empregado, pois ele sabe que está em uma situação experimental dentro da empresa. Afora o exame admissional, nós temos o exame periódico anual, embora para as áreas administrativas esse exame possa ser postergado por até dois anos, mas por um modelo que nós temos na empresa e que iguala isso para todas as áreas, tanto nas áreas de risco como nas áreas administrativas, faz-se um exame anual do empregado. A sistemática é um pouco variada, ocorrendo durante o ano inteiro, e cada localidade tem uma metodologia: data de admissão do empregado, data de nascimento, data de matrícula, ordem alfabética... Nós temos diversos modelos porque a empresa é muito grande em 
termos de extensão, está no estado todo e a gente não pode querer fazer uma padronização até porque a gente impactaria em questões administrativas e operacionais. Na empresa nós não realizamos manutenção clinica, até porque nós oferecemos ao funcionário o atestado de condições bucais. Nós incentivamos o empregado portador de problemas a sair e procurar por tratamento, porque a empresa adota a seguinte filosofia: não podemos ficar a vida inteira tomando o funcionário pela mão, ele precisa adquirir algumas responsabilidades que têm que ser arcadas por ele, porque se não a empresa adota um papel muito paternalista e impede o desenvolvimento das pessoas, elas acabam ficando acomodadas, então o que nós fornecemos ao empregado? A informação, que talvez seja a maior carência do país. Ele de posse disso, tem o livre arbítrio de procurar o profissional que quiser, o serviço que quiser para resolver a necessidade dele. Outra linha que justifica o não atendimento dentro da empresa é que, em primeiro lugar você não agradaria a todos, o que seria um problema administrativo para nós; segunda coisa: digamos que um funcionário desses venha a ter qualquer outro problema dessa ordem: 'Ah... eu achei que a restauração não ficou esteticamente boa'... Ele teria como acionar a empresa por responsabilidade solidária, não seria o profissional que seria responsabilizado e sim a empresa, que estaria dando guarida àquele serviço, então veja que tem aí influência jurídica. Temos mais duas modalidades de exame: aquele em que o funcionário é submetido ao mudar de função; muitas vezes o que acontece é que o exame periódico dele foi feito há mais de 90 dias, e para que ocorra essa mudança funcional, para que ela se efetive, o empregado faz esse exame. 0 impacto disso é que muitas vezes o empregado sai de uma área que não exige dele tanta clareza de comunicação quanto a próxima função que vai exercer. Só para exemplificar: o indivíduo é um profissional que trabalha no almoxarifado e de 
repente, por um concurso interno, vai para o cargo de eletricista porque tem formação técnica para isso. No almoxarifado a condição de comunicação não era tão fundamental para ele, mas como eletricista ele vai receber e dar comandos na parte de trânsito de energia elétrica, então o que acontece se esse indivíduo estiver com uma prótese removível solta, mal adaptada, ou mesmo uma prótese provisória, ou se tiver uma prótese total sem o devido reembasamento? Esse empregado também recebe uma orientação especial, exatamente por causa da mudança funcional dele, porque a sua situação bucal irá interferir no processo de comunicação dele no momento em que ele for para a outra função; evidentemente, dentro da mesma linha do exame admissional, ele não vai ser impedido, mas vai ser informado com outros dados que talvez para a função anterior não eram tão enfatizados. E por último tem o exame demissional, que serve tanto para a odontologia do trabalho quanto para a medicina: se o empregado fez o exame periódico dentro dos 90 dias, ele não tem a necessidade de passar por esse exame, porém se passar mais de três meses do exame periódico, a empresa quer ter o controle pela saída dele e para passar as últimas orientações, reforçando alguns aspectos, porque a partir daí esse empregado não terá mais o monitoramento feito pela empresa, incentivando esse indivíduo a dar continuidade aos controles de saúde bucal. Também há os exames emergenciais, nos casos de acidentes, e aquilo que a gente chama de exame de acompanhamento, consultas excepcionais, quando o empregado tem alguma dúvida e vem esclarecer essa dúvida com a gente e aí sim, até por uma filosofia da própria empresa, muitas vezes essa dívida não é necessariamente do empregado, mas atinge um filho, parente mais próximo, a esposa, porque nós entendemos da seguinte maneira: se esse empregado estiver preocupado, com uma dúvida mesmo que não seja dele, mas de um parente -, isso pode levar a distúrbios de 
concentração, e conseqüentemente a acidentes. Portanto, mesmo que seja uma duvida da família, a gente esclarece para que ele volte para o campo de trabalho de uma forma mais despreocupada daquela questão em si. O meu trabalho, que introduziu o protetor labial e o protetor de pele dentro da empresa, trabalho que eu acabei publicando pela própria empresa, foi justamente fundamentado no alto risco da radiação - não radiação elétrica, mas radiação elétrica não ionizante - solar, mais especificamente do ultravioleta, com vários casos diagnosticados e vários casos que apresentam grande propensão; hoje, depois de 10 anos da introdução do protetor específico para isso, a gente vê que o impacto, a incidência diminuiu bastante, mas é o tipo da coisa que a gente tem que continuar o tempo todo monitorando, porque a radiação solar é cumulativa, e a gente não tem um histórico do indivíduo antes da empresa, só depois de ele entrar na empresa. Nós aqui, até pelo fato de investirmos muito na ação preventiva com a intenção de recuperar as doenças, principalmente as periodontais, que sabidamente interferem em outras manifestações sistêmicas como o desbalanceio de diabetes, o próprio risco de endocardite bacteriana -, para nós a endocardite bacteriana é um negócio seriíssimo, porque se o indivíduo vier a ter uma lesão valvular, qualquer coisa que altere o funcionamento cardiológico dele, esse indivíduo não pode mais entrar na área de risco, ele vai ter que ser readaptado, readequado numa função em que as alterações cardiológicas não sejam um impeditivo. Nas áreas em que a ferramenta fala, existe uma queixa no que diz respeito à articulação da parte neuromuscular; em outro grupo, você vê uma incidência maior de periodontopatias, que vão incitar inevitavelmente uma sialorréia; também temos determinadas funções energizadas, nas quais o indivíduo não pode sequer ejetar saliva para fora da boca - e é muito comum o indivíduo que trabalha no campo criar o hábito de não engolir o excesso de saliva cuspi-la, como o jogador de 
futebol, mas se ele jogar qualquer forma de umidade, seja saliva ou urina, ele fecha um arco de voltagem e morre lá em cima, enquanto está energizado. Enquanto está passando energia na roupa dele, ele não pode criar nenhum campo de umidade em volta dele, porque essa umidade é condutora de energia elétrica e pode causar uma descarga nesse funcionário e levá-lo a óbito, porque nós não trabalhamos com energia abaixo de 88.000 volts, então essa questão é importante. Outro aspecto que eu venho trabalhando dentro da companhia diz respeito ao pessoal que atua em função que envolve força física: esses indivíduos, ao longo dos anos de atividade profissional, vão perdendo a habilidade manual fina, então a incidência de periodontopatias é muito mais alta do que no pessoal de escritório. Hoje, durante o treinamento, nós apresentamos diferentes formas de higienização bucal para o operador, para o eletricista, para o funcionário administrativo, porque cada um deles tem uma particularidade. Por exemplo, a grande preocupação do administrativo é a estética porque é o cartão de visita dele, ele se contacta com outras pessoas fora da empresa, o foco dele é um pouco diferente , a queixa principal dele muda."

EMPRESA F - "Nunca foi feito nenhum levantamento para saber se tem alguma sintomatologia relatada por paciente da mesma área, mas eu já percebi, geralmente esse pessoal que trabalha na linha de produção tem muito bruxismo, são pessoas muito tensas. Os executivos, que vivem em reunião, também podem ficar aqui dez minutos e têm que sair correndo, ou estão aqui e o telefone está tocando, não têm sossego, muita tensão... Não percebi outra sintomatologia a não ser o bruxismo, que quase 99\% tem.” 
EMPRESA G: "No exame admissional, que é um exame médico ocupacional, o cirurgião-dentista faz uma avaliação e analisa, não sei se a visão da odontologia ocupacional é atendida nesse momento, mas é feita uma avaliação clínica e o cirurgião-dentista dá um parecer: se a situação da saúde bucal do candidato é muito problemática, e vai envolver um custo muito alto para tratamento, ele faz a sugestão de quanto aproximadamente custe e aí ao médico dá o OK na contratação do ponto de vista médico. O médico do trabalho leva em consideração a condição da saúde bucal que o candidato tem. Caso, claro, no momento em que o funcionário é contratado, o cirurgião-dentista faça uma orientação para que ele já, o mais rápido possível, se inscreva para fazer o tratamento, se há tratamento de urgência, será realizado logo após a contratação ou, se for tratamento de rotina, ele se inscreve e aguarda o momento para fazer o tratamento. Não são oferecidos prótese, implante ou ortodontia, é oferecido o plano básico e até endodontia. Não é realizado exame periódico da cavidade bucal, mas sugere-se ao funcionário que ele passe por um exame preventivo, que tem demorado em torno de um ano e meio se eu fizer uma programação. Quanto aos outros exames ocupacionais, não são realizados: nem o de retorno ao trabalho, nem o demissional, nem o de mudança de função, não há exames odontológicos com essas características. Os dados são arquivados em um prontuário - que atualmente passa por uma modificação - médico dentro do qual existe a ficha odontológica admissional e o registro dos tratamentos a que o funcionário foi submetido. Quando o funcionário chega, é retirada a parte odontológica do prontuário e ele é encaminhado ao cirurgião-dentista com essa ficha odontológica em mãos; o cirurgião-dentista faz as anotações e a ficha volta para o prontuário médico: todos os tratamentos realizado são anotados nessa ficha. Quanto ao exame admissional, a avaliação médica é realizada por mim ou pelo meu colega, 
que é clínico, mas temos bastante experiência, e temos uma visão geral da saúde global. Além disso, a ênfase recai sobre o aspecto ocupacional: o que o indivíduo faz, em que área ele trabalha, se existe alguma queixa pertinente à área principalmente em termos de lesões por esforços repetitivos/doenças originadas da rotina de trabalho. Mas é claro que uma pessoa que é operadora de uma máquina de solda e que eventualmente abre a máquina - que tem um teor na solda de chumbo - passa por uma anamnese própria, e é submetida ao exame que avalia o teor de chumbo no sangue. Com regularidade, tem o de estanho também, o $R X$ do tórax, mas esse fica particularmente para o médico de trabalho. Isso é o que compõe o exame médico ocupacional. Quando nós julgamos que há a necessidade de realizar exames laboratoriais, da bioquímica geral do funcionário, fazemos a solicitação, mas os exames ocupacionais toxicológicos são realizados anualmente, tanto na área de chumbo quanto na área de pintura; lá eu pesquiso solvente pela urina. Eu pergunto como a parte odontológica entraria nessa avaliação, como é que você julga? Deve-se estudar muito, ver o que tem em pesquisa e trazer para a gente, e aí evidentemente nós colocaríamos o profissional com essa visão na empresa. O cirurgião-dentista faz uma avaliação para ver se a condição de saúde bucal do candidato à vaga está tão deteriorada que sua admissão vai custar muito; vamos dizer assim: para a recuperação daquela condição bucal o dispêndio será muito alto, então... O custo... Se for um funcionário raro... Mas, se é um candidato que concorre com outro, de qualidades semelhantes, e um tem uma saúde bucal adequada e o outro não tem, vou preterir o último. Eu acho que aí valeria a pena você me trazer isso, as pessoas que estão nessa linha de atuação, e eu acho que valeria a pena, você deve ter todo um material que relaciona problemas da saúde bucal com alguma exposição nos ambientes ocupacionais. No momento em que 
esse link for feito, e a gente carece disso, tanto é que eu estou há 27 anos aproximadamente 28 - fazendo medicina ocupacional, e é a primeira vez em que me deparo com uma profissional falando em odontologia ocupacional, e olha que já fui a quase todos os congressos, o que é uma experiência razoável. Para uma empresa grande, quando ocorre o acidente de trabalho - alguns trabalham até com incidente de trabalho, ou seja, não chega a ter a lesão física -, essas empresas esmiúçam o acidente ou até o incidente, vão atrás, na origem, no cerne da questão, avaliam o ocorrido em diversas áreas. Nós fazemos os estudos epidemiológicos de rotina, parte pertinente à área de medicina ocupacional, da parte odontológica não. Não é enfocado esse tema, a única coisa, evidentemente, é que eu faço a dosagem de chumbo no sangue para aquelas pessoas que têm exposição - por mínima que seja - a essa substância; nós fazemos aí o controle de chumbo no sangue através de um laboratório conceituado em São Paulo, e nunca tivemos problema nenhum de níveis acima do normal de chumbo no sangue, sempre foram bem baixos, é claro que em uma situação em que houvesse um grupo de funcionários que tivesse valores limítrofes, ou que tivesse o chumbo no sangue elevado, haveria então uma avaliação da parte bucal também. Eu estou há 15 anos aqui e sempre tivemos a odontologia aqui, não era a empresa atual, mas outra, que era uma antiga prestadora de serviços e que funcionava da mesma maneira que a atual. Essas queixas até podem existir, mas nunca foram tratadas assim, como conseqüência de um agente epidemiológico, se elas devem ocorrer com uma grande parcela da população, mas nunca foi chamada a atenção, olha esse grupo de funcionários tem uma incidência maior de queixas de halitose ou seja lá o que for e que nos preocupasse a relacionar a uma situação de trabalho, uma situação de alimentação, 
sabe-se lá o que pudesse estar interferindo, ou uma patologia que pudesse estar incidindo na cavidade bucal dos nossos funcionários."

EMPRESA J: “No caso dos exames periódicos, não é feita avaliação odontológica, porque a cada seis meses eles estão aqui no ambulatório odontológico, com essa parte o Dr. Luis não se preocupa, mesmo porque o convênio já fornece essa assistência. Na admissão sim, ele faz a avaliação, não é um fator para barrar, dependendo do cargo. Por exemplo: um cozinheiro não pode ter os dentes em estado deplorável, os médicos indicam o que deve ser feito ou informam ao funcionário que ele tem determinado tempo para cuidar desse problema, então não é a empresa que vai arcar com isso, a empresa não assume esses gastos para a admissão. Enquanto candidato ele faz, é responsabilidade dele. Não. Isso vai muito de cirurgião-dentista mas eu, quando faço um exame inicial procuro, além do dente, olhar a língua, a mucosa, porque eu sempre gosto de falar uma coisa. Por exemplo, se o indivíduo é fumante eu gosto de falar que esse é um dos fatores desencadeantes do câncer de boca, dá sempre para passar uma informaçãozinha, porque é claro que não dá para ficar aqui, no ritmo que eu atendo, horas falando muito, mas dentro do possível, o que eu puder passar de informação já é importante. Qualquer lesão suspeita é encaminhada para o semiologista do convênio, para avaliação mais especializada.”

EMPRESA - L: "Aqui o exame admissional não é obrigatório, nós fazemos um periódico uma vez por ano. O funcionário é obrigado a vir aqui, e o controle se dá pela data de admissão do funcionário; por exemplo, ele entrou em abril, então todo ano em abril é feito um exame periódico medico e odontológico, mesmo que ele não 
queira tratar aqui, que ele tenha um cirurgião-dentista particular dele, ele tem que passar aqui, eu faço um exame, avalio as condições bucais dele e oriento sobre o que ele deve fazer: se ele quiser tratar aqui, tudo bem; se ele quiser tratar com o cirurgião-dentista particular dele, ele já esta orientado. O exame admissional não tem avaliação odontológica, só médica, eu não sei por que, eu não sei se é lei, o que é isso, acho que não é obrigatório. A visão desse exame é mais assistencial, informar o funcionário sobre o que ele tem e o que precisa ser realizado, não é muito concentrada no progresso, não temos estatística, não há necessidade disso, pelo menos nunca foi necessário proceder desse modo. Tem um controle, todas as fichas de todos os pacientes que eu atendo são guardadas; quando aparece um paciente antigo, não são muitos, mas tem paciente que eu trato há 12 anos, então você vê quer dizer, é um levantamento meu - o comprometimento dele quanto à saúde bucal, tem paciente em que eu só faço limpeza e remoção de tártaro superficial, então você vê que houve uma melhora, o pessoal melhorou; tem o pessoal que é chão de fábrica, normalmente é um pessoal um pouco inferior, e você percebe que na primeira consulta são 12 cáries, retração, endodontia, mas com o passar dos anos, você vê que vai diminuindo, quem fica aqui bastante tempo já não tem tantos problemas porque a empresa dá atenção, exames periódicos, a gente liga lá e chama o pessoal, eles vêem que é serio e acabam se comprometendo. Aqui quase todos os funcionários fazem tratamento, mas eu tenho notado, já há algum tempo alguns problemas: alguns funcionários que ficam desempregados muito tempo, quando entram na empresa sabem que têm que vir aqui; a empresa não fala nada, mas acho que é da cabeça dos funcionários, eles acham que se saírem do serviço para vir para cá o chefe ficará bravo, onde ele está... Que ele está indo muito ao cirurgião-dentista, isso é da cabeça do funcionário, pois quase todos os chefes 
passam por aqui também e saem do local para vir aqui, porque o procedimento da empresa de realizar algumas coisas, eu não, nesses 16 anos, se eu dei atestado para justificar falta ao trabalho foram dois ou três. Normalmente, se a pessoa vem com dor de dente, eu atendo aqui e ela volta para trabalhar. Se ela não dormiu a noite toda de dor e eu percebo, atesto e mando ela embora para que não sofra nenhum acidente aqui dentro da empresa, mas normalmente ninguém sai daqui, dificilmente alguém sai daqui. No caso de o paciente ter procurado o cirurgiãodentista particular, ele vai me ligar, eu vou dar o Ok pra ele e no dia posterior ele vai passar aqui para que eu avalie, para eu fazer esse exame, para constatar se é verdade: eu tenho que assinar o atestado, eu é que libero o empregado, independentemente de ele ter passado aqui ou no cirurgião-dentista particular. $O$ pessoal pergunta muito sobre halitose, freqüência de tártaro."

EMPRESA - N: "Na parte bucal a gente olha também, mas a gente não pode atuar porque a gente não tem convênio com a parte odontológica, aí a gente recomenda ao funcionário que cuide, se tem dor de dente, se tem algum problema com dente, com a gengiva, se tem sangramento."

Das empresas investigadas neste trabalho, 53,33\% realizam exames odontológicos ocupacionais mas, como estes não são obrigatórios por lei, sua aplicação se dá de diferentes formas. Observa-se maior freqüência de exames odontológicos admissionais e periódicos, de acordo com o que preconizam Midorikawa (2000) e Walls e Bethlem (1942), para quem os exames odontológicos pré-admissionais e periódicos auxiliam na prevenção de doenças bucais e no 
diagnóstico de manifestações bucais decorrentes de doenças profissionais, as quais podem ocasionar a diminuição da capacidade laborativa dos empregados.

Especificamente, Thomas (1943) destaca a responsabilidade do cirurgiãodentista quando este realiza o exame bucal do paciente, pois as doenças bucais podem originar infecções em outras partes do corpo. O autor postula que o exame da cavidade bucal deve ser minucioso pois os abscessos dentários são potencialmente perigosos, não apenas pela possibilidade de transferência da infecção e de toxinas para outras partes do corpo, mas também porque causam diminuição da resistência do organismo.

Entretanto, como se verifica nos trechos de entrevistas apresentados anteriormente, a grande maioria das empresas estudadas não valoriza adequadamente @s exames odontológicos ocupacionais. Não existe preocupação formal com o delineamento de um perfil epidemiológico das condições de saúde bucal dos trabalhadores, mesmo em empresas cuja atividade implica a exposição constante dos funcionários a cargas tóxicas deletérias, o que colide com o preconizado na Lei Orgânica da Saúde (BRASIL, 1990), que define saúde do trabalhador como "um conjunto de atividades que se destina, através das ações de vigilância epidemiológica e sanitária, à promoção e reabilitação da saúde dos trabalhadores, submetidos aos riscos e agravos advindos das condições de trabalho". Com raras exceções, até mesmo os cirurgiões-dentistas entrevistados parecem desconhecer a importância de analisar concretamente a epidemiologia e a patologia dos problemas bucais que acometem os trabalhadores, e avaliar o impacto que possam ocasionar na qualidade de vida destes (ARAUJO; GONINI JUNIOR, 1999). 
Ainda guardadas as honrosas exceções, a interação entre os exames odontológicos ocupacionais e as ações educativas - interação esta que caracteriza os programas de promoção em saúde bucal - praticamente inexiste. Tais exames, na esmagadora maioria das vezes, são realizados sob a égide de uma "filosofia de desobrigação": a empresa provê a realização dos exames e, portanto, cumpre o seu papel de atendimento às demandas sociais. Aí se esgota a sua ação, aí ela se resguarda de eventuais processos trabalhistas. Diferentemente do que defendem Paulo, Cury e Ferreira Junior (2002), tais exames não se inserem em um contexto maior, não reforçam o trabalho educativo dos programas de saúde bucal implantados, não possibilitam a informação e a formação do trabalhador, não contribuem para a detecção de novos riscos e doenças, e menos ainda possibilitam a avaliação dos resultados dos programas implantados.

\subsection{Absenteísmo decorrente de Problemas Relacionados à Saúde Bucal}

Na primeira metade do século passado, a ADA (1946) já ressaltava que a realização de estudos que demonstrassem a interação absente ísmo-doenças bucais promoveria o aumento do número de programas voltados à manutenção da saúde bucal nas empresas.

Em pesquisa qualitativa realizada com usuários do serviço de emergência da faculdade de odontologia de Piracicaba da Universidade Estadual de Campinas, Brito Jr. (2000) verificou os seguintes percentuais para afastamentos decorrentes de intercorrências odontológicas: 3 dias, 12,7\%; 2 dias, 47,3\% e 1 dia, 30,9\%. Já 
Martins (2002), que investigou o absenteísmo por causas médicas e odontológicas em duas empresas - uma pública e outra privada - constatou que, de um total de 5.693 dias de afastamento, 89 tinham etiologia odontológica, e que $81,3 \%$ das ausências ao trabalho por motivos odontológicos implicavam faltas de pelo menos um dia.

Investigando os afastamentos do trabalho decorrentes de problemas odontológicos em servidores públicos municipais de São Paulo, Mazzili (2004) obteve tempo médio de ausência de 5,4 dias.

Nesta pesquisa, $60 \%$ das empresas estudadas apresentavam casos de afastamento por problemas odontológicos, com predominância de períodos de ausência de um a três dias. Os entrevistados das empresas restantes $40 \%$ da amostra) não se recordavam de afastamentos por esse motivo.

EMPRESA A: "Até dois dias, o empregado pode negociar diretamente com a gerência dele, que manda o atestado para nós, apenas para nós incluirmos no nosso programa de controle de absenteísmo. É aí que às vezes pode ter alguma falha, mas do ponto de vista normativo está tudo coberto direitinho. Acima de dois dias nós temos que avaliar sempre, então ele apresenta o atestado e a gente vai avaliar se aquela solicitação condiz com a condição clínica dele ou não; isso traz algumas situações embaraçosas, porque às vezes eles trazem dez atestados e você constata que se trata de tratamento eletivo, que nós não liberamos. Também já houve situação que nós acabamos abonando para não entrar em choque, inclusive de caráter ético, com quem concedeu o abono; se o caso tivesse prosseguido um pouco mais nós teríamos que intervir, nem que fosse através de conselho, porque a pessoa teve muitos afastamentos relacionados a situações clinicas pouco evidentes. 
Também houve caso de pessoa gritando de dor, e você, sem ter como medir, tem que acreditar; em tais situações nós gerenciamos a questão junto ao chefe da pessoa sem, evidentemente, entrar em detalhes: informamos que o afastamento era decorrente de problemas de saúde dentária, e que nós aguardaríamos e avaliaríamos, acompanhando o caso mais de perto, e aí a pessoa sentiu que a coisa 'estava pegando' e milagrosamente se curou. Isto porque, obviamente, você tem que tomar cuidado com a interação com os outros colegas, até conceder um atestado na maior boa vontade, acreditando na dor do indivíduo."

EMPRESA B: "Não é verificado pois há flexibilidade de horário."

EMPRESA C: "Sim, existe mas não costuma ultrapassar dois ou três dias. Nesses casos, o cirurgião-dentista emite um atestado e dá abono. Posteriormente será realizada uma perícia relacionada à ocorrência."

EMPRESA D: "Existe afastamento por motivo odontológico, a freqüência dos afastamentos tem como motivo principal a dor; eventualmente a gente pega um processo infeccioso inflamatório, o indivíduo aparece com edema, dor, calor, rubor, com a face aumentada... Houve um caso, que nós tratamos junto com o cirurgiãodentista do convênio, de algia do trigêmeo, e outro de descompressão cirúrgica, pela compressão do nervo trigêmeo. Em geral uma semana de afastamento, cada caso é um caso, mas o que se tem visto é em torno de uma semana."

EMPRESA E: "Tem outro serviço dentro da empresa, chamado controle de absenteísmo, até porque antes de ter a odontologia do trabalho dentro da empresa 
como ela é formalizada hoje, existia uma norma em que atestados de cirurgiãodentista só eram validos em situações de emergência e urgência. Quando eu entrei na empresa eu sempre questionava: 'quem diz o que é emergência e o que não é emergência odontológica??? Dentro dessa filosofia de deixar o empregado sair para se tratar somente quando chega na situação de emergência, mais ou menos estão empurrando o empregado a só dar atenção para a situação quando a coisa está pegando fogo e não da forma preventiva, com diagnóstico preventivo, precoce do distúrbio. Hoje não, hoje o empregado tem sim a liberdade de sair para fazer o tratamento necessário, a gente incentiva inclusive, as novas linhas de gerentes hoje também compreendem que é melhor dispensar um empregado para fazer o tratamento odontológico, pois o número de horas investido nesse tratamento é muito menor do que se a gente deixar o quadro se agravar; quando isso acontece, inevitavelmente o empregado terá que ficar afastado de 8 h00 a 16 h00 laborais, o que corresponde a 24 a 48 h00 de afastamento. Então isso é também um trabalho que a gente faz na parte do absenteísmo, que é bastante rigorosa porque a unidade adotada na empresa é hora-homem-trabalho. Nós não produzimos uma coisa palpável: energia elétrica não é palpável, ela só é utilizada, mas você não tem como compartimentalizar ou mesmo mensurar o quanto foi investido naquele exato momento, então a gente trabalha com horas-homem investidas para fazer um determinado trabalho, ou quantas horas-homem desse indivíduo foram perdidas na frente de trabalho, por isso a moeda de mensuração dentro da empresa sempre vai ser essa. As indústrias que produzem bens materiais podem aferir isso pela linha de montagem de produção, mas nós não temos como fazer isso, nós sempre temos que colocar uma unidade, que é o homem presente para fazer uma atividade dentro da empresa. Retorno ao trabalho: bem, nós não afastamos, ou melhor, procuramos 
não afastar ninguém, exceto quando ocorre um acidente e salvo quando são lesões cancerizáveis de boca, esses casos a gente tem que estar acompanhando, mas a gente nem espera o empregado voltar ao trabalho, a gente faz acompanhamento periódico. Até 2003, o armazenamento dos dados foi feito de forma separada, apesar de que a documentação oficial da empresa, o chamado prontuário de saúde, fica armazenado em um lugar só, mas como a odontologia do trabalho é uma área que precisa gerar muitos relatórios, é uma área de estudo dentro da empresa, ele fica armazenado na própria área. Já que o empregado tem um exame anual, nós temos um monitoramento dele e partimos do principio de que todos são responsáveis até que provem o contrário. Então, a partir do momento que o empregado procure tratamento, a gente até prefere que não seja emergencial, que seja a assistência de rotina. Se o empregado usar a hora laboral, saindo uma ou duas horas mais cedo ou chegando duas horas mais tarde, usar o período da tarde para fazer isso, deve trazer uma declaração de que esteve lá, até por uma questão do acidente de trajeto: se ele se acidentar no meio do trajeto ele tem um atestado dizendo que estava fora da empresa fazendo uma coisa que a empresa autoriza . Se ele foi lá fazer uma determinada restauração e deu exposição endodôntica e o profissional afirma a necessidade de repouso, além da declaração ele deve trazer um atestado, comprovando a solicitação de dispensa. Todos esses atestados passam por um controle da área, nós temos um grande problema com os cirurgiõesdentistas que não usam CID; eles geralmente colocam o procedimento que adotaram, e não o estado ou patologia que levou o empregado ao atendimento; então, na grande maioria das vezes eu tenho que entrar em contato, não para fazer auditoria no atestado, mas para conseguir classificar a causa do atendimento de acordo com o CID. Então vamos supor que um gerente ache que o empregado 
esteja usando o atestado de forma indevida: ele solicita que nós façamos um acompanhamento; num primeiro momento eu tenho a ficha do ano anterior, eu olho e vejo se os procedimentos são compatíveis e, se não forem compatíveis, eu solicito a presença do empregado para fazer uma auditoria naqueles atestados, justamente para não penalizar o coletivo pela atitude de alguns poucos. Se tiver que penalizar, vamos penalizar o acusado, não a totalidade, mas isso é computado, são realizados relatórios mensais sobre o ocorrido e, no final do ano, saem no relatório anual o número de horas e o número de dias que foram investidos nisso daí. Assim, nós temos um controle do número de dias de afastamento, e a somatória daquelas horas mostra para a empresa quanto ela investiu em horas em uma situação social. Acúmulo de horas totais em 2004: 58 horas de afastamento; total de dias (inteiros): 6 dias. Não é um impacto assim tão grande, visto que a nossa população já tem um certo controle."

EMPRESA F: "É dado atestado somente para casos de extração e implante, só cirurgia, tem que especificar tudo, depois passar na área médica; eles liberam. Não é realizada perícia caso o funcionário realize tratamento lá fora, aí é com a parte médica que traz o atestado."

EMPRESA G: "O cirurgião-dentista emite o atestado médico. Como uma avulsão dentária, o dentista faz um dia e, se necessário, esse funcionário se apresenta e faz dois dias, ou alguma coisa com características que impliquem dificuldade do trabalhador para exercer a sua função, e necessidade de se de afastar do trabalho. Tanto aqui como qualquer cirurgião-dentista da rede credenciada, trazendo um atestado odontológico, o atestado passa por nós, a gente dá um visto, defere e 
segue os trâmites normais, vai lá para o processo de justificativa da falta, não é feita nenhuma perícia."

EMPRESA H: "Os casos de afastamento são relacionados no departamento médico, nunca houve um caso de afastamento odontológico que perdurasse por mais de 15 dias - o que gera alguma entrada no INSS. De um, dois dias eu posso garantir que sim, porque isso tem acontecido. Às vezes eles até passam por aqui, mas ocasionalmente, para saber com quem tratar e a gente orientar até o ambulatório, mas posso garantir que não passa de dois, três dias, mesmo a saída deles não é em uma freqüência grande, não. Nesses afastamentos, se o empregado não trouxer o atestado ele não terá o abono, mas se ele trouxer, a empresa não se opõe, a não ser que seja um caso de afastamento por mais de 15 dias, é claro que a gente vai ter que intervir. Qualquer atestado é aceito, a não ser que gere duvida, é como na parte médica, se o atestado a qualquer momento gerar alguma dúvida para a empresa, se o empregado está usando de má-fé, ou se existe algum problema com aquele atestado, a empresa averigua, é como com a assistência médica. A gente tem o convênio, nunca aconteceu de haver fraude em atestado, nada disso, às vezes, eventualmente, dependendo do histórico daquele funcionário, a empresa tem que fazer um acompanhamento mais de perto, com o próprio local, para realmente saber o que está acontecendo e ter um relatório médico, então vamos supor que um atestado médico é de 15 dias: a empresa procura ter um relatório do problema desse funcionário para que isso, de repente não venha a gerar nenhum desconforto futuro, porque às vezes um afastamento de 15 dias passa ser de mais tempo, então a empresa tenta saber qual diagnóstico foi levantado, para acompanhar a vida e a saúde do funcionário. No caso odontológico, como nunca passou desse período - 
15 dias -, nunca teve caso de afastamento, a empresa aceita sem problemas, não questiona atestados e tudo mais. A não ser que o atestado venha em condições de suscitar dúvidas."

EMPRESA I: "Afastamento de fato por motivo odontológico eu não tenho nenhum, falta eu até posso ter, mas como a gente tem essa questão da flexibilidade, aonde eu tenho uma documentação forte é no call center, onde a gente tem que controlar o horário, mas eu posso dizer que não me lembro de ter atestado de cirurgião-dentista, ou o volume de tratamento dentário ser grande, eu não me lembro, sempre são outros motivos. Para as áreas que são administrativas isso é banco de horas, mas o call center, que é o pessoal de atendimento, que atende para dar informação, vender algum produto, o telemarketing, e tem uma área de retenção. De 1.060 funcionários, 600 pessoas estão no call center. Como eles estão sob um forte controle, eu posso falar que intercorrências dentárias não são problema, não tem uma demanda significativa, eu acho que as pessoas resolvem isso no seu horário, porque o pessoal do atendimento trabalha seis horas: tem gente que trabalha de manhã e tem a tarde livre, eles acabam tendo tempo de ir ao médico, ao cirurgião-dentista. 0 pessoal administrativo usa banco de horas: se o empregado foi ou não foi ao médico ou ao cirurgião-dentista ninguém tem controle disso. Muita gente faz tratamento, usa aparelho, faz limpeza, vai na hora do almoço ou pede para sair uma ou duas horas mais cedo, mas isso é controle do próprio gestor, a gente é bem flexível nisso... A gente tem feito levantamento para saber a quantidade de afastamentos porque assim, acima de 15 dias eles entram no INSS, então essas pessoas que estão acima de 15 dias estão em número elevado, nenhuma por motivos dentários; dos que estão abaixo de 15 dias é meu maior volume, são pessoas que praticamente vão 
trazendo o atestado. Como a gente vem fazendo o acompanhamento dessas pessoas que se afastam por menos de 15 dias para poder saber o que está acontecendo - até para ter um absenteísmo um pouco menor -, eu não me lembro de ninguém ter me falando de afastamento por motivo odontológico por três a quatro dias, ou um que seja, pode ter, quando o funcionário vai tirar um dente do siso tem, mas o numero é bem baixo. Não é realizada perícia: caso o funcionário diga que foi ao cirurgião-dentista ele vai trazer o atestado e OK, ele é aceito."

EMPRESA J: "Os funcionários que tiverem que ir ao cirurgião-dentista na hora do expediente trazem o atestado e levam direto ao setor de Recursos Humanos, não é realizada perícia odontológica. Hoje mesmo eu tive que extrair três dentes de uma paciente que fala muito no telefone, então eu dei o dia de hoje e o dia de amanha para não ter problema e a cicatrização ser mais rápida, mas eu geralmente dou no dia e sempre converso com o paciente para agendar mais perto do fim-de-semana, e informo que às vezes dá complicação. Enfim, se o atestado do dia não for suficiente, e se não for possível entrar em contato ou passar aqui para que eu possa avaliar e olhar, e se tiver necessidade, eu atesto... Mas geralmente por cirurgia, que é um ou dois dias, não vai ser mais de que isso. Afastamento por motivo odontológico, sim, tem, mas assim: exodontia, dor pulpar mais violenta, cirurgia ortognática, nos já tivemos casos aqui de cirurgias ortognáticas de empregados, exodontias múltiplas, nós tivemos um caso de uma pessoa uma ocasião que eu tive que deixar um bom tempo afastada, porque na época ainda se usava telefonista, ainda existia o cargo, e ela era telefonista e não tinha como falar, coitada, mas tem, nós temos registro sim, e estamos trabalhando esses registros para torná-los mais efetivos, porque a odontologia tem um problema: a maior parte dos afastamentos são curtos, salvo 
situações de cirurgia oral maior, e nós temos aqui uma flexibilidade de 48 horas, nas quais o chefe pode resolver o problemas sem passar pela área de saúde, embora a gente recomende a orientação, então existe um pouco de perda desses dados. No momento essas questões estão sendo trabalhadas, para ver se a gente consegue apurar essas coisas um pouquinho melhor."

EMPRESA K: "Poucos, não temos um controle disso, mas com certeza tem."

EMPRESA L: "É muito difícil acontecer."

EMPRESA M: "Nunca tivemos afastamento por motivo odontológico, apenas auxiliodoença e maternidade. Não é feita perícia, apenas com o atestado é dado baixa."

EMPRESA N: "O afastamento é registrado através dos atestados, e não passa de dois a três dias, não passa disso."

Embora na amostra avaliada não haja registros de ausências prolongadas ao trabalho em virtude de problemas odontológicos, Midorikawa (2000) destaca que o trabalhador que apresenta quadro com sintomatologia dolorosa de causa bucal e/ou dentária sente-se desconfortável no trabalho, esteticamente diminuído, e apresenta sinais e sintomas que vão desde a diminuição da atenção (absenteísmo de corpo presente) e a ausência ao trabalho (absenteísmo de corpo ausente) até alterações comportamentais devidas à tristeza, à vergonha e à inibição de sorrir, o que implica problemas de relacionamento com as demais pessoas. Assim sendo, é necessário que os profissionais que militam na área de saúde do trabalhador 
passem a considerar também as intercorrências de ordem psicológica decorrentes da precária saúde bucal. Se não pelos danos que estas acarretam ao indivíduo, que o façam pela queda quantitativa e qualitativa da produção.

\subsection{Programas de Promoção em Saúde Bucal}

Das empresas investigadas no presente estudo, 60\% têm algum tipo de programa de promoção da saúde bucal, e/ou fornecem orientações e estimulam a valorização da saúde bucal junto aos seus empregados - no próprio PCMSO ou como através de atividades e ações isoladas -, enquanto 40\% não abordam temas odontológicos nas ações direcionadas à saúde do trabalhador. De acordo com a NR7 (BRASIL,1998b), o PCMSO tem como objetivos promover e preservar a saúde do trabalhador, incumbindo ao empregador a elaboração, a implementação, a administração, o gerenciamento e os custos das ações voltadas a esse fim.

Partindo de estudos epidemiológicos e voltados à prevenção, o PCMSO prioriza a preservação da saúde do trabalhador vinculado à empresa frente a situações de risco iminente. Esse programa, de caráter multi-setorial, deve envolver todos os setores da empresa. A política empresarial deve ser orientada quanto à necessidade de apoio ao programa - participação da diretoria e dos administradores na sua implantação -, e a responsabilidade de cada membro da empresa, de acordo com os níveis hierárquicos, é fundamental para a sua boa consecução: Diretoria, CIPA, SESMT e trabalhadores (ASSUMPÇÃO, 2004). 
A elaboração do PCMSO compreende, obrigatoriamente, Ações de Saúde Primárias - desenvolvidas antes da instalação do processo de doença - e Secundárias - período patogênico, visando o diagnóstico precoce e a recuperação da saúde do trabalhador - voltadas à promoção e à prevenção da saúde de todos os trabalhadores da empresa, aí se incluindo palestras e treinamentos (ASSUMPÇÃO, 2004).

Os papéis e responsabilidades atinentes ao PCMSO estão bem definidos: cabe ao empregador garantir que este seja elaborado e implementado na sua empresa e custear todos os procedimentos necessários para tal; compete ao médico coordenador realizar todos os exames previstos, ou atribuí-los a profissionais médicos e serviços de propedêutica complementar competentes para a sua execução (DIAS, 2002).

De acordo com Possibom (2001), o PCMSO deve ser planejado de forma a apresentar ações de saúde a serem executadas durante o ano, levando em consideração questões incidentes sobre o indivíduo e a coletividade de trabalhadores. Além disso, faz-se necessário elaborar relatórios anuais, nos quais sejam discriminados, por setor da empresa, o número e a natureza dos exames médicos - incluindo as avaliações clínicas e os exames complementares -, estatísticas de resultados considerados anormais, assim como o planejamento para o próximo ano - que deve ser reavaliado sempre que ocorrerem alterações dos riscos ambientais na empresa.

O PCMSO e a Vigilância em Saúde do Trabalhador devem manter o foco nas diferenças entre os gêneros feminino e masculino, com ações sensíveis a essa ótica (BRITO, 1997). 
A seguir, a título de ilustração, são apresentadas partes das entrevistas realizadas, nas quais os entrevistados comentam sobre os Programas de Promoção da Saúde Bucal nas empresas.

EMPRESA A: "O próprio exame periódico mostra que ele não é feito com a conotação exclusiva de exame clínico. Durante esse exame são passadas orientações preventivas, e nas datas comemorativas nossas, como por exemplo o Dia Mundial da Saúde Bucal, nós sempre fazemos algum evento voltado para os dependentes e os empregados. Nós temos aqui uma coisa que se chama 'diálogo diário de segurança, meio ambiente e saúde: A gente vai descendo os andares e fala cinco minutos alguma coisa, então existe uma preocupação muito grande de orientação das pessoas, sim. Na Semana de Saúde a odontologia sempre entra, é feito como regra geral; se nosso sistema de saúde prevê nos procedimentos atividades que remetem à promoção e à proteção, então nós temos procedimentos - tais como a terapêutica básica - que incluem, além da profilaxia básica, mais simples, quando não há um comprometimento periodontal, a orientação nutricional e preventiva de maneira geral. Claro que a gente tem dificuldades, nem sempre os credenciados cumprem o requisito, mas existe essa ferramenta no próprio sistema de saúde, além de outras coisas como o flúor, que isso já é mais regrado."

EMPRESA C: "Sim, existe a parte de promoção de saúde que é exigida por lei. Há palestras apresentadas nas áreas e manutenção preventiva que é realizada na consulta periódica. Foi montado um escovódromo na semana da saúde, que é feita uma vez por ano com uma visão educativa e integrada com a medicina. Há o programa 'dente de aço', um projeto realizado com os filhos dos funcionários; é 
aberta uma inscrição para se ter uma base de quantas crianças serão; são realizadas diversas atividades, entre elas teatro de fantoches, apresentação de audiovisual, desenhos, grupo interativo caracterizado, palestras educativas para os pais e escovódromo. Há o interesse de montar um projeto direcionado aos adultos."

EMPRESA D: "Possui sim, chama programa de qualidade de vida da empresa. Nós temos aí várias ações de promoção: tem ações voltadas para a família e ações voltadas para o empregado. Nas ações voltadas para a família tem o encontro das esposas, no qual que se fala sobre câncer de mama, câncer de outras partes do organismo, planejamento familiar, sexualidade etc... Tem acampamento de jovens e adolescentes de várias faixas etárias, onde se fazem vários eventos de prevenção e promoção de saúde, quer dizer, aproveita-se aquele levantamento epidemiológico para fazer nesses encontros as ações de saúde. Há também as ações dentro da empresa, como ginástica laboral, academia de ginástica dentro da empresa - temos duas academias montadas dentro da empresa - sem custo nenhum para o empregado; ele faz dentro do horário que pode. A ginástica laboral é de pausa e aquecimento. Existem também as palestras da semana interna de prevenção de acidentes, as palestras nas unidades para higiene pessoal, existe o pessoal do SESI, que atua com a gente na campanha de coleta de sangue e na avaliação de epidemias, taxas de colesterol, triglicérides, glicemia e palestras sobre hipertensão, diabetes e obesidade. Nós temos restaurantes dentro da empresa, e a nutricionista também orienta sobre a alimentação balanceada; eventualmente nós também convidamos alunos de faculdade vinculados à odontologia preventiva para falar sobre prevenção oral, uso do fio dental, escovação dentária; isso é feito também na Semana Interna de Prevenção de Acidentes de Trabalho (SIPAT). Nós temos 
também, dentro da promoção de saúde, jogos interunidades, Copa de Esportes uma vez por ano, são várias modalidade de que os funcionários participam. Existe também a campanha de imunização, então a gente faz vacinação gratuita contra gripe, levantamento estatístico para justificar a vacinação para o ano seguinte. Isso já vem sendo feito há seis anos. Então nós temos isso, as ações de saúde são voltadas para as atividades esportivas, a atividade física ligada à ginástica laboral, a sinesioterapia, a educação da postura global, as palestras educativas, desde AIDS até higiene pessoal. Apesar de termos dificuldade devíamos ter um cirurgião-dentista que seria mais fácil, mas temos na SIPAT a prevenção oral."

EMPRESA E: "O próprio PRODOC, Programa de odontologia ocupacional, que já chama assim porque foca o monitoramento e a promoção de saúde bucal. Ele é composto pelos exames, controle, e depois tem as ações educativas. Anualmente nós temos uma campanha de venda promocional de produtos de higiene bucal para os empregados, que é com preço mais acessível. Nas SIPATs tem sempre um tema de saúde bucal incluso, é fundamental que tenha; esse ano a empresa resolveu elaborar um brinde padronizado para os empregados, uma nécessaire com todos os instrumentos de higiene bucal, para que ele possa levar para o campo, para que ele possa deixar na mesa de trabalho dele; a empresa participa linkando a logomarca da empresa com a questão da saúde bucal. As palestras, são inúmeras palestras; mensalmente nós temos de 15 a 30 minutos para falar sobre o nosso tema, então a gente escolhe o tema que a gente quer. Existe outro material de informação, que são os folders de informações, e servem de suporte para as palestras que são dadas. Isso assim em termos de promoção de saúde, o carro-chefe da nossa parte didático-informativa." 
EMPRESA F: “Viva Bem'. São realizadas palestras, campanhas, semana de saúde, tem os informativos que nós colocamos no restaurante, explicando um tema por semana: halitose, problema periodontal, implante... A gente deixa na porta de saída dos dois restaurantes, o pessoal passa e pega. É uma maneira que a gente encontrou de fazer essa promoção, porque a gente não pode fazer no jornalzinho, então fazendo esses panfletos o pessoal sai e pega, é uma maneira de mais ou menos ir conscientizando. Muito paciente liga aqui perguntando, diz que leu o informativo e acaba vindo aqui e tirando as dúvidas e tal. A gente tem liberdade de comunicação com a área da saúde, de trocar informações. Não tenho conhecimento de diagnóstico de lesões. Eles fazem campanhas médicas de saúde, mas não odontológica, eu vejo assim, é mais por cultura do brasileiro achar que saúde odontológica é coisa secundária. A odontologia é uma coisa secundária, e não dá pra avaliar a saúde geral sem ver a bucal, é uma coisa que deixa o cirurgião-dentista chateado; o brasileiro tem esse negócio na cabeça de que dente não é uma coisa tão importante quanto, uma gripe, um resfriado, quanto um dedo, uma perna. E não é nem só dente, mas eles associam a dente, muita gente vem aqui e tem um tratamento de canal mas prefere arrancar, pois já arrancaram vários e você tem que explicar que dente é importante, tem a mastigação e você já começa a entrar nesse todo, estômago, digestão, vai te atrapalhar, você tem que conscientizar o paciente que acha que dente é só arrancar e pronto."

EMPRESA G: "Nós temos os programas pertinentes à área de saúde ocupacional como um todo, e essa área de saúde bucal está envolvida também, nós fazemos regularmente algumas campanhas promocionais de saúde, falamos sobre a importância da saúde bucal, e habitualmente na semana interna da saúde - uma 
semana que nós reservamos para falar de saúde, promover a saúde fundamentalmente através de palestras, através de panfletos, de cartazes. Nós temos uma rede interna de televisão, e através dessa rede a gente promove saúde de maneira geral. Evidentemente que nessa semana a saúde bucal tem lá o seu espaço, também participando do contexto geral de saúde da população. São fornecidos folhetos, são colocados cartazes, já tivemos palestras de alguns odontólogos aí, falando sobre cuidados básicos e promoção de saúde bucal.”

EMPRESA H: "Na verdade, temos um programa de qualidade de vida, que tem palestras, mas um programa odontológico específico não existe, embora no começo do ano, tenha ocorrido uma visita de uma empresa que não oferece serviço odontológico, mas oferece um levantamento da saúde bucal dos funcionários. Eles têm uma taxa, colocam um equipamento dentro da empresa, como se fosse um ônibus, um carro grande, e esse carro é um consultório, então eles fazem uma análise sem custo nenhum para o empregado, na verdade nós temos o custo de trazê-los até aqui e mantê-los aqui pelo tempo que a gente desejar, e eles conseguem fazer um mapeamento da boca do funcionário, avaliam em que condições se encontra a saúde bucal dele, mas isso foi uma proposta feita no começo do ano por uma empresa que presta esse serviço, mas a gente não incluiu ainda no programa qualidade de vida. Achamos interessante e inclusive está na pauta para este ano, dentro do planejamento que foi discutido agora em fevereiro este é um dos temas de levantamento. Talvez, como que a gente mostra para o funcionário em que pé se encontra a saúde bucal dele, e aí ele pode buscar recursos e eventualmente, até a gente entrar mais na linha que eu já te falei, como está a vida dele, a saúde dele, para a gente poder encaminhar ou até firmar 
convênio com algum lugar para poder encaminhá-lo. Eu não me lembro, pelo menos no ultimo ano e meio, de nada ligado à saúde bucal, palestras não, não me lembro..."

EMPRESA I: "A gente está desenvolvendo um programa de qualidade de vida ainda este mês, mas ele é informativo, eu não me lembro de termos tratado o tema Saúde Bucal especificamente. O programa de qualidade de vida vai ser elaborado em cima da demanda dos próprios colaboradores [empregados], então eles vão responder questionários, e através dos hábitos dessas pessoas nós vamos direcionar essas informações. Então vai ter informações de forma genérica e feedbacks individuais, nisso aí a empresa não vai entrar, só a empresa que a gente contratou vai falar direto com o funcionário, então você que disse que tem o hábito de fazer isso e isso, é comum acontecer isso e isso, então se previna desta forma. Se de repente acontecer alguma coisa desse tipo, possivelmente a gente vá tratar. No ano passado, em setembro, a gente fez a SIPAT, que tratou de ' $n$ ' assuntos, e um deles foi saúde bucal, junto com a empresa conveniada. A gente fez assim: chamou pessoas para dar palestras sobre AIDS, sobre fumo, sobre câncer, e uma delas era sobre saúde bucal. A empresa conveniada trouxe todo o material e fez uma apresentação, deu várias informações sobre saúde bucal e aí, na parte da tarde do mesmo dia, ela falava sobre o plano: ela fazia uma integração do que a pessoa poderia ter ou os tipos de doenças que dão, e como ela poderia usar melhor o plano, então qual seria a melhor opção para que ela pudesse usar o plano da melhor forma, então isso foi bem legal. As pessoas gostaram, é diferente até, a saúde bucal é uma coisa que não se fala muito e é muito importante. Com relação ao call center a gente trabalha com fisioterapia e fonoaudiologia, a gente faz um trabalho 
preventivo que está fora de qualquer tipo de assistência, a gente contrata profissionais de fisio e fono e faz um trabalho como os colaboradores de forma preventiva. O que é mais comum no calcenter aqui da empresa é a questão das lesões por esforços repetitivos, problemas auditivos, mas assim a única pessoa que teve problemas com a articulação é uma que teve um acidente, bateu o rosto no bando do carro."

EMPRESA J: "A SETAPART, que é a semana nacional de prevenção e assistência de saúde no trabalho da empresa, realizada aqui dentro. A gente procura trazer palestrantes, profissionais da área de saúde nesse período, então são realizados exames de hepatite, diabetes, câncer de mama, vem o ginecologista fazer palestra, então nessa semana a gente procura se concentrar para que todos possam ver e assistir, pelo menos uma vez por ano. Já tivemos a abordagem de temas bucais, por exemplo, no ano passado nós tivemos uma empresa de convênio odontológico, cada ano a gente tenta trazer temas diferentes para não ficar cansativo, mas a saúde bucal sim. Eles têm uma pessoa na empresa de convênio odontológico que faz só essa parte de palestras, e essa pessoa vai com todo o material, dá palestras , todas as orientações, traz os kits, e o pessoal adora, vai lá só para pegar o kit.”

EMPRESA L: "Vem sempre um pessoal, não só odontológico, mas aborda diabetes, hipertensão. Neste ano, na parte odontológica teve palestra com ortodontista, mas tem a semana da saúde e a saúde bucal sempre está junta, é obrigatória."

EMPRESA M: "Nunca foi realizada uma ação voltada para a odontologia. No nosso caso, nós não temos muito afastamento, mas é um beneficio para o empregado, o 
que é muito bom, de grande valia, porque o sindicato tem o convênio dele, mas é mais demorado, então se nós tivéssemos aqui, seria mais fácil, até mesmo para nós controlarmos quando há necessidade de saída para ir ao cirurgião-dentista, pois não temos como ter este controle."

EMPRESA N: "Tem, tem sim, mas na área médica. Nós fazemos campanhas de prevenção de colesterol, hipertensão, diabetes, e assim por diante, vacinações... Nunca foi levantado o tema de saúde bucal, veja a importância que não se dá a isso. Quer dizer, aqui no Brasil é tudo na base do empurrão. Se fosse lei, tranqüilo, que deveria ser... Olha, eu sempre falei que deveria, por que não a parte odontológica estar no PCMSO, por que não??? Qual é o problema, é área médica também, é de igual importância, deveria estar lá na lei. Se não é obrigado e gera custos, até logo... Geralmente essas campanhas duram uma semana, dependendo três dias, agora não, porque o número de funcionários é pequeno, agora são dois, três dias no máximo."

Os trechos de entrevistas apresentados neste item demonstram que, nas empresas avaliadas, os programas de promoção em saúde bucal, quando existem, são incipientes. Esse quadro não surpreende pois, como ressalta Pizzatto (2002), ações dessa ordem iniciam-se com algumas atividades e, paulatinamente, vão ganhando espaço até adquirirem a feição de programas propriamente ditos, direcionados especificamente para a empresa que os sedia.

Talvez esse seja o caminho possível, mas mais adequado seria planejar tais programas a partir do censo odontológico, como postula Midorikawa (2000). Esse ponto de partida - o levantamento das condições bucais da equipe - permitiria que 
as ações de promoção e prevenção fossem direcionadas desde o início para o atendimento das necessidades de empregados e empregadores. Por óbvio, essas partes - empregado e empregador - nutrem expectativas diferentes em relação a tais programas: enquanto para os trabalhadores a iniciativa deve prover a melhoria da qualidade de sua saúde, o empregador espera que eles garantam condições satisfatórias de saúde a seus funcionários para aumentar a produtividade e os lucros da empresa (PIZZATTO, 2002). Essa diferença de perspectiva, entretanto, não significa conflito, até porque ambas as partes, embora com objetivos diversos, convergem naquilo que se constitui no cerne desse tipo de iniciativa, que é a melhoria da qualidade de vida do indivíduo.

Assim, ao modificar os valores dos trabalhadores em relação à sua condição bucal através de campanhas educativas, a Odontologia do Trabalho atende aos interesses de todos os envolvidos no processo: o trabalhador, que ganha em qualidade de vida e auto-estima, e a empresa, que tem seus custos diminuídos e sua margem de lucro aumentada (SILVA; SOUTO, 1983a, b, c).

Nesse contexto torna-se evidente a importância do cirurgião-dentista do trabalho, que é o agente das mudanças esperadas. Como observam Guimarães e Rocha (1979a, b, c), cabe a esse profissional fornecer, com o auxílio de material didático e ilustrativo, orientações práticas e teóricas acerca da higiene bucal, levando os indivíduos a compreenderem que os dentes não têm função meramente estética, mas permeiam toda a condição de saúde. 


\section{CONCLUSÕES}

A revisão de literatura efetuada possibilitou o entendimento da relação saúde e trabalho, bem como da presença e importância do cirurgião-dentista inserido no quadro de profissionais envolvidos nos cuidados à saúde dos trabalhadores. Da análise e discussão dos resultados obtidos no presente trabalho, conclui-se que:

- embora não obrigatório por lei federal, $20 \%$ das empresas entrevistadas incluem o profissional cirurgião-dentista na equipe multidisciplinar do SESMT;

- apenas $13,33 \%$ das empresas relataram a participação direta ou indireta desse profissional na CIPA;

- no que se refere a serviços odontológicos disponibilizados pela empresa, $80 \%$ das empresas investigadas possuem algum tipo de serviço odontológico, 33\% das quais possuem atendimento localizado no espaço físico da empresa.

- das empresas pesquisadas, 25\% já implantaram a Odontologia do Trabalho em seus sistema de saúde;

- na amostra avaliada, 53,33\% realizam exames odontológicos ocupacionais; como estes não são obrigatórios por lei, tais empresas aplicam-nos de diferentes maneiras, com maior índice de freqüência para os admissionais e periódicos;

- $60 \%$ das empresas entrevistadas já apresentaram casos de afastamento por motivo odontológico, com predomínio de ausências por períodos de um a três dias;

- no que concerne a programas de promoção em saúde bucal, $60 \%$ das empresas estudadas desenvolvem algum tipo de ação com esse objetivo, seja por meio de 
orientações e valorização da saúde bucal no próprio PCMSO, seja através de atividades e ações isoladas;

- dada a escassez de trabalhos voltados à saúde bucal dos trabalhadores, faz-se necessária a continuidade de estudos nessa área.

O Apêndice C traz o Programa de Saúde Bucal dos Trabalhadores proposto no capítulo 3 desta dissertação. 


\section{REFERÊNCIAS ${ }^{1}$}

$2^{\text {a }}$ Conferência Nacional de Saúde Bucal; 1993 set. 25-27; Brasília. Brasília: Ministério da Saúde; 1993. 1v.

2ª Assembléia Nacional de Especialidades Odontológicas; 2001 set. 6-9;

Manaus. Manaus: Conselho Federal de Odontologia; 2001. 1v.

American Dental Association. Absenteeism and dental diseases. J Am Dent Assoc 1946;33:1154-5.

American Dental Association. Dental service in industry. J Am Dent Assoc 1942;29:299-301.

Analista de Sistema: saúde, processos de trabalho, trabalho, fatores de risco. Brasília: MTE/SIT/DSST, 2000. 77p.

Araujo ME, Gonini Junior A. Saúde bucal do trabalhador: os exames admissional e periódico como um sistema de informação em saúde. Odontologia e Sociedade 1999;1(1-2):15-8.

Araujo ME. Estudo da prevalência das manifestações bucais decorrentes de agentes químicos no processo de galvanoplastia: sua importância para a área de saúde bucal do trabalhador [Tese de Doutorado]. São Paulo: Faculdade de Odontologia da USP; 1998.

Armitage, GC. Bases biológicas da terapia periodontal. São Paulo: Editora Santos; 1984. p.204-16.

Assumpção SO. PCMSO: programa de controle médico de saúde ocupacional. São Paulo: Clisamet Serviços Médicos; 2004.

De acordo com Estilo Vancouver. Abreviaturas de periódicos segundo base de dados MEDLINE. 
Assunção AA, Lima FPA. A contribuição da ergonomia para a identificação, redução e eliminação da nocividade do trabalho. In: Mendes R. Patologia do trabalho. $2^{a}$ ed. São Paulo: Atheneu; 2003. p.1768-89.

Atlas. Segurança e medicina do trabalho: lei $n^{\circ} 6.514$, de 22 de dezembro de 1977. 48a ed. São Paulo: Atlas; 2001.

Bellusci SM. Doenças profissionais ou do trabalho. $2^{a}$ ed. São Paulo: SENAC; 1996.

Bimstein E, Matsson L. Growth and development considerations in the diagnosis of gengivits and periodontitis in children. Pediatric Dent 1999; 21:186-91.

Brasil. Consolidação das leis do trabalho. 23aㅡ ed. atual. e aum. São Paulo: Saraiva; 1998a. [Legislação brasileira].

Brasil. Constituição da República Federativa do Brasil. São Paulo: Saraiva; 1989. [Legislação Brasileira].

Brasil. Decreto $n^{\circ} 3.048$, de 06 de maio de 1999. Aprova o regulamento da Previdência Social, e dá outras providências. Diário Oficial da União, Brasília (DF) 1999 maio 12. Sec. 1:1.

Brasil. Lei n 8.212, de 24 de julho de 1991. Dispõe sobre a organização da Seguridade Social, institui plano de custeio e dá outras providências. Diário Oficial da União, Brasília (DF) 1991 jul. 25.

Brasil. Ministério da Saúde. Doenças relacionadas ao trabalho: manual de procedimentos para os serviços de saúde. Brasília: Ministério da Saúde; 2001. [Série A. Normas e Manuais Técnicos, n.114].

Brasil. Ministério da Saúde. Lei n 8.080, de 19 de setembro de 1990. Dispõe sobre as condições para a promoção, proteção e recuperação da saúde, a organização e o funcionamento dos serviços correspondentes, e dá outras providências. Diário Oficial da União, Brasília (DF) 1990 set. 21; Sec. 1, Pt. 2: 18055. 
Brasil. Segurança e medicina do trabalho, lei $n^{\circ} 6.514$, de 22 de de dezembro de 1977 , normas regulamentadoras (nr) aprovadas pela portaria $n^{\circ} 3.214$, de 8 de junho de 1978, normas regulamentadoras rurais (nrr) aprovadas pela portaria $n^{\circ}$ 3.067, de 12 de abril de 1988 e índices remissivos. 39ª ed. São Paulo: Atlas, 1998b. [Manuais de Legislação Atlas, v.16].

Brito J. Uma proposta de vigilância em saúde do trabalhador com a ótica de gênero. Rio de Janeiro: Cad Saúde Publica; 1997;13(2).

Brito Jr. RB. Avaliação retrospectiva dos pacientes atendidos e do tratamento oferecido no serviço de emergência da FOP/UNICAMP entre os anos de 1989 e 1997 [Dissertação de Mestrado]. Piracicaba: Faculdade de Odontologia de Piracicaba da UNICAMP; 2000.

Brock, DW. Industrial dentistry and the general practitioner. Ind Med Surg $1958 ; 27(5): 244-8$.

Brunetti MC. Periodontia médica: uma abordagem integrada. São Paulo: Senac; 2004. (Apresentação).

Buischi YP. Promoção de saúde bucal na clínica odontológica. São Paulo: Artes Médicas: EAP/APCD; 2000.

Calvielli ITP. Lei no 5.081, de 24 de agosto de 1966, "regulamenta o exercício da odontologia no Brasil". In: Silva M. Compêndio de odontologia legal. Rio de Janeiro: Medsi; 1997. cap.2, p.15-38.

Carrion V. Comentários à Consolidação das Leis do Trabalho. 27ª ed. atual. e ampl. São Paulo: Saraiva; 2002.

Conselho Federal de Medicina. Resolução n 1488, de 6 de março de 1998. Dispõe de normas específicas para médicos que atendam o trabalhador. Diário Oficial da União, Brasília (DF) 1998 mar. 18; Sec. 1, p.79.

Conselho Federal de Odontologia. Resolução CFO 25/2002, de 16.05.02: estabelece as áreas de competência para atuação dos especialistas em disfunção temporomandibular e dor orofacial; odontogeriatria; odontologia do trabalho; odontologia para pacientes com necessidades especiais e em ortopedia funcional dos maxilares e dá outras providências. Diário Oficial da União, Brasília (DF) 2002 maio 28; Sec. 1:148-9. 
Conselho Federal de Odontologia. Resolução CFO 42/03, de 20.05.03: revoga o Código de Ética Odontológica aprovado pela Resolução CFO-179/91 e aprova outro em substituição. Diário Oficial da União, Brasília (DF) 2003 maio 22. Disponível em: URL: http://www.cfo.org.br/download/codigo_etica.pdf [2005 fev. 05].

Conselho Federal de Odontologia. Resolução CFO-22/2001, de 27.12.01: baixa normas sobre anúncio e exercício das especialidades odontológicas e sobre cursos de especialização revogando as redações do Capítulo VIII, Título I; Capítulo I, II e III, Título III, das Normas aprovadas pela Resolução CFO-185/93, alterada pela Resolução CFO-185/93, alterada pela Resolução CFO 198/95. Diário Oficial da União, Brasília (DF) 2001 dez. 28. Disponível em: URL: http://www.cfo.org.br/atos [2005 maio 23].

Conselho Federal de Odontologia. Resolução CFO-53/2004, de 20.05.04: altera o título III da consolidação das normas para procedimento nos Conselhos de Odontologia. Diário Oficial da União, Brasília (DF) 2004 maio 22. Disponível em: URL: http://www.cfo.org.br/atos [2005 maio 23].

Crosato E, Mazzilli LEN, Crosato EM; Biazevic MGH, Crosato IR. Odontologia do trabalho: novo mercado de trabalho. São Paulo: Revista XXV de Janeiro $2005 ;(38): 26-7$.

Crosato, IR. O controle do biofilme dental no contexo da promoção de saúde bucal [Monografia de Especialização]. São Paulo: Faculdade de Odontologia da Universidade Camilo Castelo Branco; 2004.

Davis FA. Dicionário médico enciclopédico Taber. 17ª̣ ed. São Paulo: Manole; 2001.

Dejours C. Por um novo conceito de saúde. Rev Bras Saúde Ocup $1986 ; 14(54): 7-11$.

Dias EC. Organização da atenção à saúde no trabalho. In: Ferreira Júnior M. Saúde no trabalho: temas básicos para o profissional que cuida da saúde dos trabalhadores. São Paulo: Roca; 2002. cap.1, p.4-28.

Dias EC; Mendes R. O que é medicina do trabalho: definições, subdivisões, a que se destina. In: D’Assumpção, EA. Livro das especialidades médicas. Belo Horizonte: Coopmed; 2000. p.109-15. 
Dória AM. Infortunística e odontologia. Rio de Janeiro: A Noite; 1941.

Duffy B. Dental problems in the offshore oil and gas industry: a review. Occup Med;1996;46(1):79-83.

Dunning JE. Steps in the initiation of an industrial dental service. J Am Dent Assoc 1942;29(11):1523-7.

Encyclopaedia of occupational health and safety. $4^{\text {th }}$ ed. Genebra: ILO; 1998.

Ferreira RA. O valor da saúde bucal nas empresas. Rev Assoc Paul Cirurg Dent 1995;49(2):96-107.

Frazão P, Narvai PC. Promoção da saúde bucal nas escolas. In: Araujo ME, Narvai PC, Castellanos, R, Frias AC, Forni TIB, Kuwada SS, Biazevic MGH, Marques RAA, Fratucci MV, Junqueira SR. Saúde coletiva em odontologia. São Paulo; 2001. p.25-

8. [Apostila da Disciplina de Saúde Coletiva em Odontologia - Faculdade de Odontologia da USP].

Grande RHM. Prevenção e promoção de saúde dental [Tese de Livre Docência]. São Paulo: Faculdade de Odontologia da USP; 2002.

Guimarães E, Rocha AA. Odontologia do trabalho: $1^{\text {a }}$ parte. Organização dos serviços odontológicos de uma empresa. Odontólogo Moderno 1979a;6(7):7-12.

Guimarães E, Rocha AA. Odontologia do trabalho: $2^{2}$ parte. Organização dos serviços odontológicos de uma empresa. Odontólogo Moderno 1979b;6(8):23-6.

Guimarães E, Rocha AA. Odontologia do trabalho: 3ª parte. Organização dos serviços odontológicos de uma empresa. Odontólogo Moderno 1979c;6(9):4050.

Lacaz FAC. Saúde dos trabalhadores: cenários e desafios. Cad Saúde Pública 1997;13(2):7-19. 
Lotufo RFM, Panutti CM. Efeitos diretos dos patógenos bucais nas condições periodontal e sistêmica. In: Brunetti MC. Periodontia médica: uma abordagem integrada. São Paulo: SENAC; 2004. cap.2, p.41-58.

Machado JMH. Processo de vigilância em saúde do trabalhador. Cad Saúde Publica 1997;13(supl 2). Disponível em: URL: http://www.scielo.pnp!scriptsci_arttex [2005 jul. 23].

Marano VP. Organização de serviços de medicina do trabalho nas empresas. São Paulo: Ltr; 1989.

Martins RJ. Absenteísmo odontológico e médico no serviço público e privado [Dissertação de Mestrado]. Araçatruba: Faculdade de Odontologia da UNESP; 2002.

Mazzilli LEN. Análise dos afastamentos do trabalho por motivo odontológico em servidores públicos municipais de São Paulo submetidos à perícia ocupacional no período de 1996 a 2000 [Dissertação de Mestrado]. São Paulo: Faculdade de Odontologia da USP; 2004.

Mazzilli LEN. Odontologia do trabalho. São Paulo: Editora Santos; 2003.

Mendes R. Patologia do trabalho: atualizada e ampliada. $2^{a}$ ed. São Paulo: Atheneu; 2003. v.1.

Midorikawa ET. A odontologia em saúde do trabalhador como uma nova especialidade profissional: definição do campo de atuação e funções do cirurgião-dentista na equipe de saúde do trabalhador [Dissertação de Mestrado]. São Paulo: Faculdade de Odontologia da USP; 2000.

Minayo-Gomes C, Thedim-Costa S. A construção do campo da saúde do trabalhador: percurso e dilemas. Cad Saúde Publica 1997;13(supl 2):95-109.

Moraes RGB, Dias LZS, Furtado MAH. A doença periodontal e o seu relacionamento com as doenças cardiovasculares. In: Brunetti MC. Periodontia médica: uma abordagem integrada. São Paulo: Senac; 2004. cap.9, p.217-50.

Nadanovsky P. Promoção da saúde e prevenção de doenças bucais. In: Pinto VG. Saúde bucal coletiva. São Paulo: Editora Santos; 2000. cap.9, p.293-310. 
Offenbacher S, Beck JD. Medicina periodontal: o papel da infecção periodontal no estresse sistêmico, na doença cardiovascular e nos resultados anormais da gestação. In: Brunetti MC. Periodontia médica: uma abordagem integrada. São Paulo: SENAC; 2004. cap.5, p.113-48.

Organização Internacional do Trabalho. C-161, de 25 de junho de de 1985a: Convênio sobre os serviços de saúde no trabalho. Disponível em: URL: http://ilolex.ilo.ch:1567/scripts/convds.pl?query=C161\&query0=C161\&submit =Visualizar [2005 ago. 22].

Organização Internacional do Trabalho. R-171, de 26 de junho de 1985b: Recomendação sobre os serviços de saúde no trabalho. Disponível em: URL: http://ilolex.ilo.ch:1567/scripts/convds. pl?query=R171\&query1=R171\&submit=Vis ualizar [2000 ago. 22].

Paulo AF, Cury R, Ferreira Junior M. Gestão e gerência de programas preventivos de saúde nas empresas. In: Ferreira Junior M. Saúde no trabalho: temas básicos para o profissional que cuida da saúde dos trabalhadores. São Paulo: Roca; 2002. cap.4; p.67-79.

Pereira, AC. Odontologia em saúde coletiva: planejando ações e promovendo saúde. Porto Alegre: Artmed; 2003.

Persona D, Persona MER. Manual de saúde e segurança ocupacional. São Paulo: SEBRAE; 1998.

Pessini L, Barchifontaine CL. Problemas atuais de bioética. 4르 ed. São Paulo: Loyola; 1991.

Pettiboni EL. Industrial dentistry. J Am Dent Assoc 1923;10:1030-1.

Petty FF. What is necessary to make industrial dentistry a credit to the dental profession? J Am Dent Assoc 1943;30:1418-27.

Pinto VG. Saude bucal: odontologia social e preventiva. $3^{\underline{a}}$ ed. São Paulo: Editora Santos; 1994.

Pinto VG. Saúde bucal: panorama internacional. $2^{\underline{a}}$ ed. Brasília: Ministério da Saúde; 1990. 
Pizzatto E. A saúde bucal no contexto da saúde do trabalhador: modelos de atenção [Dissertação de Mestrado]. Faculdade de Odontologia de Araçatuba da UNESP; 2002.

Possibom WLP. NRs 7, 9 e 17 PCMSO; PPRA; ergonomia: métodos para a elaboração dos programas. São Paulo: LTr; 2001.

Ramazzini B. As doenças dos trabalhadores. Trad. de Raimundo Estrela. São Paulo: Fundacentro; 1992.

Sallum AW, Martins AG, Sallum EA. A doença periodontal e o surgimento de um novo paradigma. In: Brunetti MC. Periodontia médica: uma abordagem integrada. São Paulo: Senac; 2004. cap.1, p.21-40.

São Paulo. Cidade. Secretaria Municipal da Saúde. Vigilância em saúde: saúde do trabalhador. Disponível em: URL:

www6.prefeitura.sp.gov.br/secretarias/saude/vigilancia_saude/trabalhador/0001 [16 jan. 2005].

Segre M. Ética em saúde ocupacional. Rev Assoc Med Bras 1989;35(2):75-8.

Seixas MM. Os princípios da administração na odontologia empresarial: procurando definir padrões de qualidade [Dissertação de Mestrado]. São Paulo: Faculdade de Odontologia da USP; 2001.

Sgreccia E. Manual de bioética: fundamentos e ética biomédica. São Paulo: Loyola; 1996.

Shilling RS. More effective prevention in occupatinal health practice. Journal of the Society of Occupational Medicine 1984;39(2):71-9.

Shour L, Sarnat BG. Oral manifestations of occupatinal origin. J Am Med Assoc 1942;120(15):1197-207.

Silva RB, Souto DF. Modelo de serviço assistencial em odontologia ocupacional 1 a parte. Odontol Mod 1983a;10(9):36-9. 
Silva RB, Souto DF. Modelo de serviço assistencial em odontologia ocupacional 2.․ parte. Odontol Mod 1983b;10(10):39-45.

Silva RB, Souto DF. Modelo de serviço assistencial em odontologia ocupacional

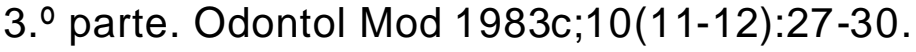

Thomas EH. Mouth infection in industrial workers: a serious menace to general health; resultant loss to work production. J Am Dent Assoc 1943;30:1249-62.

Vianna MIP, Santana VS. Exposição ocupacional a névoas ácidas e alterações bucais: uma revisão. Cad Saúde Pública 2001;17(6):1335-44.

Walls RM, Bethlem P. A dental program for industry. J Am Dent Assoc 1942;29:1083-9.

Wehba C, Rodrigues AC, Soares FP. Diabetes e doença periodontal: uma relação bidirecional. In: Brunetti MC. Periodontia médica: uma abordagem integrada. São Paulo: SENAC; 2004. cap.7, p.171-96.

Westergaard J, Larsen IB, Holmen L, Larsen AI, Jorgensen B, Holmstrup B, et al. Occupational exposure to airbone proteolytic enzymes and lifestyle risk factors for dental erosion: a cross-sectional study. Occup Med; 2001;51(3)189-97.

Westerman B. Appropriate dental care for emplooyees at the workplace. Aust Dent J 1993;38(6):471-5.

World Health Organization. Constitution of the World Health Organization. Genebra: WHO; 1946. [Basic Documents, 1]. Disponível em: URL: http://oms.org/documents_constituição [2005 nov. 2].

World Health Organization. International programe on chemical safety. Genebra: WHO; 1991.

World Health Organization. Occupational exposure to mists and vapors from strong inorganic acids and other industrial chemicals. Lyon: International Agency for Research on Cancer; 1992. Monograph 54. 
World Health Organization. Program on internationally recommended healthbased permissible level for occupational exposure to chemical agents.

Luxembourg: WHO; 1978.

Yeo DKL, Pham TP, Baker J, Porter SAT. Specific orofacial problems experiened by musicians. Australian Dental Journal 2002;47(1):2-11. 


\title{
TERMO DE CONSENTIMENTO LIVRE E ESCLARECIDO
}

\author{
TEMA: \\ AVALIAÇÃO DAS CARACTERÍSTICAS DOS SERVIÇOS ODONTOLÓGICOS \\ EXISTENTES EM EMPRESAS DO ESTADO DE \\ SÃO PAULO
}

\section{OBJETIVO}

O presente estudo propõe-se a verificar a presença ou a ausência de Serviços Odontológicos nas empresas do Estado de São Paulo, buscando observar que tipo de abordagem é dado à saúde bucal do trabalhador. Será realizada uma análise dos métodos utilizados pelos empregadores para melhorar a qualidade de vida e a satisfação de seus empregados e, nas empresas em que for constatada a ausência desses serviços, serão observados os motivos da não implantação e os métodos de administração dos problemas de origem dentária.

\section{MATERIA E MÉTODO}

Será realizada uma entrevista com o cirurgião-dentista ou o médico responsável pela área de saúde da empresa e, caso não haja uma área de saúde, a entrevista será direcionada ao Departamento de Recursos Humanos.

\section{RETIRADA DO CONSENTIMENTO}

Os participantes têm a liberdade de retirar seu consentimento a qualquer momento, e deixar de participar do estudo. 


\section{Consentimento Livre e Esclarecido}

Pelo presente documento, eu, $R G$ telefone , certifico que, tendo lido o documento acima exposto, e suficientemente esclarecido(a), estou plenamente de acordo em participar do presente estudo, com a liberdade de responder apenas às perguntas que me convier, permitindo que os dados obtidos sejam utilizados para fins da pesquisa intitulada Avaliação das características dos serviços odontológicos existentes em empresas do estado de São Paulo.

Foi deixado bem claro que toda a informação colhida nesta entrevista será mantida sob sigilo e usada unicamente para fins de pesquisa, sendo garantido que a minha identidade, como também o meu ambiente de trabalho serão preservados.

$\mathrm{Na}$ visita previamente agendada via telefone, fui esclarecido(a) de que que não terei nenhum benefício pessoal, mas que as informações colhidas servirão de grande valor para a classe odontológica, e que será feita a devolução dos resultados para as empresas que colaborarem no presente estudo.

Com tudo o que foi exposto acima, autorizo que as informações colhidas sejam utilizadas na pesquisa.

Data

Assinatura:

Pesquisadora: Dra. Isis Ryal Crosato

Mestranda em Odontologia Social

Para maiores esclarecimentos, entrar em contato com o Prof. Dr. Moacyr da Silva no telefone 3091-7891. 


\section{ENTREVISTA: ROTEIRO}

* Identificação do entrevistado:

$>$ Nome

$>$ Cargo ocupado

$>$ Nome da empresa

$>$ Ramo de atividade da empresa

$>$ Número total de funcionários da empresa

* A empresa possui SESMT próprio? Quais os profissionais que compõem essa equipe? O CD faz parte dessa equipe?

* A empresa possui CIPA? O CD participa das reuniões dessa Comissão? Qual a periodicidade da reuniões da CIPA?

* A empresa oferece algum tipo de serviço odontológico aos seus funcionários?

$>$ Sob qual forma? Consultório, terceirizado (convênio), reembolso etc.

$>$ Há quanto tempo esse benefício foi implantado?

$>$ Quantos funcionários têm acesso ao serviço?

> Quais os serviços oferecidos: especialidades - geral / prótese / implantes / ortodontia -; assistencial / curativo / emergencial / preventivo / educativo / reabilitador / pericial / exames ocupacionais odontológicos

* Em caso de existência de consultório próprio:

$>$ Número de salas existentes

$>$ Aparelho de RX

$>$ Número de CDs

$>$ Carga horária de atendimento: 24h - diário?

$>$ Carga horária dos CDs

$>$ Especialidade dos CDs e tempo de formação destes

$>$ Anamnese: assistencial ou investigativa

$>$ Ficha ocupacional ou programa de computador

* Exames ocupacionais odontológicos

$>$ Admissional / demissional / retorno ao trabalho / afastamento / periódicos

$>$ Os dados dos exames são armazenados? Por quanto tempo?

$>$ Tais dados são trabalhados de forma a se constituírem em levantamento epidemiológico?

$>$ Há algum tipo de sintoma que se constitua em queixa freqüente pelos trabalhadores, como ardor, xerostomia, halitose etc.?

$>$ É praxe a realização de manutenção periódica / limpeza?

Há registros de afastamento por motivo odontológico? Qual o período mais comum? Quem elabora e abona os atestados? Qual o processo de justificativa de falta (atestado e perícia)? 
* Qual o procedimento de emergências durante a jornada de trabalho?

* A empresa possui algum tipo de Programa de Promoção de Saúde? Bucal?

$>$ Realiza palestras educativas?

$>$ Semana da saúde?

$>$ Controle periódico?

$>$ Acha interessante? Por que?

* Houve alguma melhoria com a implementação do Serviço Odontológico e do Programa de Promoção de Saúde Bucal?

$>$ Agradou os trabalhadores ?

$>$ Qual foi a repercussão para a empresa? 


\title{
PROGRAMA DE SAÚDE BUCAL DOS TRABALHADORES
}

\author{
Organização dos Serviços Odontológicos de uma Empresa
}

O momento atual é marcado por uma visão integrada de saúde, em que a saúde geral influencia e é influenciada pela saúde bucal. Sob essa ótica, a odontologia ocupa lugar de destaque no contexto da saúde dos trabalhadores, e o número de programas voltados à sua manutenção e prevenção cresce gradativamente.

A implantação de um programa de atenção à saúde bucal dos trabalhadores é delineada na política de saúde da empresa, e seu sucesso está diretamente relacionado ao valor que a empresa dá aos seus recursos humanos (trabalhadores). Para a instalação e a organização de um Serviço de Odontologia Ocupacional, é de extrema importância que haja, por parte da empresa, a real intenção de instituir, na sua estrutura organizacional, uma política de prevenção, cujos mecanismos deverão ser dinâmicos e funcionais para que possam proteger a saúde dos trabalhadores em sua integralidade.

De início, deve ser definida a subordinação hierárquica no contexto da estrutura organizacional da empresa - à Presidência, à Gerência, ao Departamento de Saúde, de Pessoal, de Recursos Humanos -, levando em consideração que muitas decisões devem ter efeito imediato, além de que o cirurgião-dentista do trabalho deverá gozar de independência econômica, técnica e moral em relação aos empregadores e aos empregados. Essa relação pode ser colocada em dúvida quando o cirurgião-dentista do trabalho está ligado à empresa por um contrato de trabalho, e sujeito portanto a algumas restrições no desempenho de suas funções. Em um segundo momento, recursos devem ser alocados para esse fim, dado que a empresa se dispõe e está decidida a organizar e manter a estrutura odontológica. Dados referentes ao número de funcionários e à área de atuação da empresa devem ser considerados. 
A chefia do Serviço de Odontologia do Trabalho é de competência de um cirurgião-dentista com especialização em Odontologia do Trabalho. Esse profissional é diretamente responsável pela organização e implementação da Odontologia Ocupacional (preventiva), e indiretamente pela orientação e acompanhamento da Odontologia Assistencial (curativa). Também sob sua coordenação estão as equipes técnica e auxiliar.

O sucesso dos programas estabelecidos pelo Serviço de Odontologia do Trabalho depende, entre vários fatores, do harmonioso entrosamento com os diversos setores da empresa comprometidos e vinculados direta ou indiretamente às atividades e aos programas do Serviço. Os Departamentos de Prevenção de Acidentes, de Recursos Humanos, de Seleção e de Recrutamento fazem parte integrante de dois importantes programas do serviço odontológico: um voltado à prevenção de acidentes e de doenças profissionais, e outro relacionado aos exames odontológicos ocupacionais.

A interação entre o Serviço de Odontologia do Trabalho e o Departamento de Laboratório Industrial - setor que recebe e analisa toda a matéria-prima que ingressa na empresa - é essencial, pois através dele serão acessados e conhecidos os produtos químicos (solventes, óleos etc.) utilizados pelos trabalhadores na empresa. Mas este é apenas o ponto de partida, pois há que serem observadas as transformações e interações químico-físicas que ocorrem ao longo de todo o processo - e que dão origem a novos agentes tóxicos. Se a empresa possuir um Setor de Alimentação para o preparo de alimentos e refeições para seus trabalhadores, a presença do cirurgião-dentista, assim como a do profissional médico e do nutricionista, é essencial, não apenas para o controle da qualidade da matéria-prima utilizada nas refeições e a elaboração dos cardápios, como também (no caso do CD) para o gerenciamento de aspectos como a compatibilidade entre a condição bucal dos qperadores e a biossegurança alimentar. Tais considerações devem ser observadas até mesmo quando do estabelecimento de contrato com empresas de fornecimento de refeições prontas. Portanto, é de grande importância identificar todos os setores da empresa, tomando conhecimento de todas as situações que permeiam a atividade laboral e mantendo um bom relacionamento com todas as chefias, além de efetuar os seus respectivos cadastramentos.

É da organização que dependerá o bom andamento do Serviço de Odontologia do Trabalho e, conseqüentemente, a sua eficiência. A seguir, são 
elencadas as providências que devem ser observadas para a implantação desse tipo de serviço:

1) Elaboração de rotinas que deverão ser seguidas igualmente por todos, em cada setor e em cada tipo de atividade que o serviço pretenda realizar, como nos exames odontológicos ocupacionais - admissionais, periódicos, demissionais, especiais -, na parte administrativa e na coleta de dados para os levantamentos epidemiológicos, entre outros. É interessante elaborar um Manual de Procedimentos especificamente destinado aos profissionais que realizarão a coleta de dados, fazendo com que haja uma calibração tanto intraexaminador (o examinador para com ele próprio) quanto inter-examinadores (caso haja mais de um profissional, equipará-los).

2) Elaboração e confecção de impressos (fichas clínicas, anamnese, formulários, receituários etc.) que servirão para agilizar e permitir o registro de tudo que ocorrerá no Serviço. Mesmo este sendo totalmente informatizado, as fichas dos pacientes, com suas respectivas assinaturas, deverão ser anexadas ao prontuário odontológico e arquivadas como documentação obrigatória. Devem também ser elaborados formulários de comunicação interna e externa, de registro de acidentes do trabalho, de registro dos dados referentes às consultas odontológicas e outras, que no decorrer do serviço se mostrarem necessárias.

3) Realização dos Exames Odontológicos Ocupacionais, partindo do princípio de que o foco do serviço é dirigido para a integridade e a saúde daqueles que constituem a comunidade sob sua responsabilidade. Ao término dos exames odontológicos ocupacionais, o cirurgião-dentista do trabalho examinador deverá emitir o seu laudo conclusivo por meio do Atestado de Saúde Bucal Ocupacional (ASBO) em três via: a primeira via será mantida no prontuário odontológico do trabalhador, a segunda entregue ao trabalhador e a terceira via entregue ao Departamento Pessoal, para constar do dossiê do empregado.

a. EXAMES ODONTOLÓGICOS ADMISSIONAIS

São realizados obrigatoriamente em todo candidato a integrar o contingente de recursos humanos da empresa e destinam-se a fornecer, ao órgão pessoal, as "indicações" e "contra-indicações" para o exercício da função pretendida. Em tese, o exame admissional constitui-se no primeiro exame periódico a que o 
trabalhador é submetido, e servirá inclusive para atualizar o Censo Odontológico da empresa. Seus princípios básicos são:

- Permitir a colocação dos trabalhadores em serviços adequados às suas condições morfopsicofisiológicas;

- Permitir que os candidatos a empregos conheçam o estado real da sua saúde bucal, sendo orientados quanto à possível solução dos problemas odontológicos eventualmente encontrados;

- Salvaguardar a saúde e a segurança da comunidade trabalhadora; e

- Permitir que o novo trabalhador receba as primeiras noções sobre aspectos ligados à saúde bucal ocupacional.

O Departamento Pessoal fornecerá, ao candidato que for recrutado e selecionado, uma relação de documentos necessários, bem como os exames subsidiários de laboratório, a ficha de anamnese (da qual deve constar uma serie de indagações que devem ser respondidas e assinadas pelo próprio candidato) e os exames radiológicos médico e odontológico (radiografia panorâmica) exigidos nos exames médico e odontológico admissionais. Só após cumpridas essas exigências o candidato retornará ao Departamento Pessoal, que o encaminhará aos exames médico e odontológico em horário pré-estabelecido, munido de toda a documentação obrigatória, incluindo documento do qual conste a função que o candidato irá exercer na empresa (daí a necessidade do conhecimento prévio de todas as funções exercidas na empresa).

O cirurgião-dentista deve estabelecer normas e diretrizes que permitam uma padronização seqüencial, o que facilitará a emissão de conclusões. Inexistem padrões de fichas odontológicas utilizadas para a realização de exames odontológicos admissionais, mas é fundamental que essas fichas sejam simples, de fácil preenchimento e completas. Inicialmente será realizado um levantamento das condições bucais e, na avaliação clínica propriamente dita, deverão constar os dados referentes aos:

- Exames dos Dentes: índice CPO - cariados, perdidos (ausentes ou extrações indicadas) e obturados;

- Exames dos Tecidos Moles: alterações patológicas encontradas na mucosa, na língua, nos lábios e nas gengivas; 
As informações obtidas na anamnese, no exame clínico e nos exames complementares deverão ser registradas no prontuário odontológico, ao qual deverá ser anexado o exame radiográfico, com a finalidade de facilitar o acompanhamento em avaliações futuras e nos exames periódicos.

Uma vez realizados os exames médico e odontológico admissionais, o candidato deverá retornar ao Departamento Pessoal munido de laudos médico e odontológico conclusivos.

Esse exame não tem o intuito de selecionar o candidato, mas sim de possibilitar o diagnóstico de alterações na cavidade bucal antes da integração do indivíduo à força de trabalho. Com base nas informações recebidas do cirurgião-dentista do trabalho, é indispensável que o candidato procure realizar o tratamento mínimo indicado, que se constitui em fator de controle do absenteísmo e de acidentes do trabalho.

Determina as necessidades dos admitidos para a inclusão no planejamento da assistência odontológica, e conscientiza o indivíduo de que a saúde bucal também é importante na obtenção de oportunidade de emprego, além de melhorar a sua qualidade de vida e a de seus familiares.

b. EXAMES OdONTOLÓGICOS PERIÓdicos

O exame periódico odontológico procura diagnosticar precocemente as alterações na saúde bucal dos trabalhadores, antes mesmo do aparecimento das manifestações clínicas, e possibilitar a sua reparação em tempo hábil, tendo caráter essencialmente preventivo. O cirurgião-dentista do trabalho deverá estar a par das manifestações clínicas orais das doenças profissionais, para diagnosticá-las e/ou encaminhá-las ao setor médico quando se fizer necessário. Esse exame possibilita o estabelecimento de interface entre as alterações da saúde bucal dos trabalhadores e o trabalho, por comparação com os resultados dos exames odontológicos periódicos anteriormente realizados, permite orientar o trabalhador com relação à manutenção do tratamento indicado pelo Censo, avaliando as necessidades odontológicas acumuladas no período.

A periodicidade desse exame varia em função de uma série de fatores. Normalmente, deve ser realizado em todo o efetivo da empresa, sendo repetido 
anualmente; em casos especiais (atividades insalubres, área da alimentação e área da saúde), deve ser mais freqüente.

O exame periódico deve ser planejado com antecedência, sendo de conhecimento do cirurgião-dentista do trabalho examinador as particularidades da função exercida pelo trabalhador e as suas condições de trabalho. A programação deve ser estabelecida conforme a população trabalhadora que se pretende examinar, e deve trazer a metodologia a ser aplicada (dependendo de cada setor), o cronograma a ser obedecido (número de exames diários, tempo de exame etc.) e o fluxograma a ser respeitado (forma de recepção do operário que se apresenta para o exame) evitando-se, assim, a perda de tempo do trabalhador no setor de saúde.

c. EXAMES OdONTOLÓGICOS DE MudANÇA DE FunÇÃO

Esse exame é destinado aos trabalhadores transferidos de função, sempre que houver mudanças profissiográficas, sendo realizado 15 dias antes da efetivação da transferência. Deve seguir o mesmo processo do exame admissional, avaliando as condições bucais do trabalhador conforme a função de risco que irá desempenhar. Ao término do exame clínico, o cirurgiãodentista do trabalho examinador deverá emitir o laudo conclusivo.

d. EXAMES OdONTOLÓGICOS DE RETORNO AO TRABALHO

Devem ser realizados desde que o trabalhador tenha estado afastado do trabalho por mais de 30 dias, por doença, parto ou acidente (do trabalho ou não). A avaliação deve constar de um exame clínico geral, com atenção às patologias que provocaram o afastamento do trabalhador (doença profissional, do trabalho ou alguma patologia comum). Ao término do exame, deverá ser emitido o laudo conclusivo, do qual conste se o trabalhador está apto ou não para o retorno imediato à função.

e. DEMISSIONAIS

Devem ser realizados até a data de homologação do desligamento dos trabalhadores, desde que o último controle tenha sido realizado:

- até 135 dias para os trabalhadores de empresas graus de risco 1 e 2 no Quadro I de NR 4; e

- até 90 dias para os trabalhadores pertencentes a empresas classificadas em graus de risco 3 e 4 do Quadro I da NR 4. 
Os procedimentos adotados são idênticos àqueles obedecidos na realização do exame odontológico periódico, com atenção para a existência de possíveis patologias ocupacionais. O exame radiológico deve ser solicitado e seu resultado deverá constar no ASBO, exigido e indispensável na conclusão da avaliação odontológica.

4) Censo Odontológico

É de grande importância para a empresa o conhecimento das reais necessidades odontológicas da sua comunidade. Deve realizar um levantamento da situação da higidez bucal dos seus empregados para o censo odontológico, visando registrar a situação atual para estabelecer um planejamento das atuações prioritárias (elaboração do exame periódico) e orientar o atendimento clínico necessário àquela população. Além disso, contribuir com a previsão do custo-benefício e do custo-produtividade dos trabalhos realizados. Esse levantamento epidemiológico servirá como base de dados para a comparação dos exames periódicos, sendo o retrato das condições bucais daquela comunidade, naquele momento.

5) Campanhas Educativas

À Odontologia do Trabalho cabe a responsabilidade de mudar a conduta dos trabalhadores em relação ao valor atribuído à saúde bucal, através de campanhas preventivas. O cirurgião-dentista do trabalho deve utilizar recursos didáticos para a leitura (folhetos informativos, cartazes ilustrativos) e campanhas de esclarecimento, ao trabalhador individualmente ou à coletividade da empresa, fornecendo orientações básicas sobre higiene bucal, técnicas de escovação, valorização dos dentes para a mastigação e para a estética, sobre os efeitos maléficos dos focos dentários e os cuidados com as gengivas, entre outros temas de interesse para o serviço. A Odontologia do Trabalho contribui para a conscientização da população com relação à prevenção de doenças de origem bucal, principalmente em um país como o Brasil, onde a renda individual é uma das mais baixas do mundo, o que por sua vez se reflete nas discrepâncias sócio-culturais. 
6) Participação nas análises profissiográficas e no processo de ergonomização Cabe ao cirurgião-dentista do trabalho, em conjunto com a equipe de segurança e saúde ocupacional, levantar os perfis profissiográficos de cada função, observando as alterações bucodentárias existentes e mantendo os empregados dentro dos limites exigidos para cada atividade. O processo de ergonomização visa promover as adaptações necessárias na relação homemtrabalho, tornando-os compatíveis entre si. O cirurgião-dentista deverá detectar todas as alterações referentes à cavidade oral, nas distintas funções e cargos, e criar mecanismos para promover e preservar a saúde bucal dos trabalhadores. A elaboração dos equipamentos de proteção individual (EPI) do complexo bucomaxilofacial é um dos mecanismos acima mencionado.

7) Arquivo Odontológico

Será indispensável a elaboração de um arquivo Odontológico, do qual devem constar a ficha clínica do trabalhador, os exames odontológicos ocupacionais (admissional, periódico, demissional) e o exame odontológico complementar (radiografia panorâmica). Esses documentos devem ser devidamente armazenados e arquivados em lugar apropriado, longe do acesso de pessoas estranhas ao Serviço Odontológico, de tal forma que possam ser rapidamente localizados quando requisitados, podendo ser relacionados de forma numérica ou alfabética.

8) Programa econômico-administrativo

Cabe ao Serviço Odontológico elaborar um programa econômico-administrativo a fim de calcular mensalmente todos os custos referentes às suas atividades, além de monitorar a efetividade das ações de saúde bucal implantadas. $\mathrm{O}$ programa irá levantar os custos diretamente relacionados aos acidentes do trabalho e às doenças profissionais de origem odontológica (com presença ou ausência de afastamento), à manutenção do serviço assistencial e à rentabilidade do Serviço Odontológico, demonstrando ao empresário a conveniência ou não de investir em programas destinados à prevenção e à proteção da saúde bucal dos trabalhadores da empresa. A ampla monitoração visa medir continuamente não só o cumprimento das ações programadas e os critérios utilizados, mas seu impacto sobre a saúde e a qualidade de vida dessa população. 


\section{9) Emergência}

Em casos de emergência de origem bucal apresentada pelos trabalhadores durante sua jornada de trabalho, de ordem traumática (acidente do trabalho) ou de sintomatologia dolorosa, o Serviço Odontológico do Trabalho, quando na ausência de serviço assistencial dentro da própria empresa, deverá fazer o pronto atendimento do trabalhador, deixando-o apto ao retorno ao trabalho ou, em caso contrário, deverá medicar e encaminhar o trabalhador ao serviço assistencial mais próximo.

10) Equipamentos necessários

a. MOBILIÁRIO

I) Recepção e sala de espera

- escrivaninha com gaveta;

- cadeira;

- computador (mouse, teclado, cpu e impressora);

- telefone;

- armário para a guarda de material de escritório e de documentos (com chave);

- cesto de lixo;

- cadeiras conjugadas;

- bebedouro;

II) Consultório

- escrivaninha com gaveta;

- cadeira;

- computador (mouse, teclado, cpu e impressora);

- telefone;

- armário para o armazenamento dos prontuários odontológicos (com chave);

- $\quad$ equipo dentário completo;

- mocho;

- aparelho de Raios X (periapical);

- armário odontológico com três módulos;

- duas pias (profissional e lavagem de instrumental);

- autoclave;

- fotopolimerizador; 
- equipamentos de proteção individual (máscara, touca, óculos, luva de procedimento e estéril e sobreluva);

b. INSTRUMENTAL CLÍNICO

- $\quad$ para exame clínico;

- para restauração dentária;

- para extração dentária;

- para endodontia;

c. Materiais de Consumo Odontológico e Medicamentos

- algodão;

- compressas de gaze;

- álcool 70\%;

- líquido de dakin;

- $\quad$ fio de sutura (3-0);

- cesto de lixo;

- lixeira descartável para pérfuro-cortantes;

- agulha descartável;

- hidróxido de cálcio;

- cimento provisório;

- $\quad$ kit fotopolimerizável (ácido fosfórico, primer/bond, resina) ;

- Soro fisiológico;

- anestésicos injetáveis locais;

- enxaguatórios bucais;

- antiinflamatórios;

- analgésicos; 


\section{PRONTUÁRIO ODONTOLÓGICO OCUPACIONAL}

\section{Ficha de Anamnese}

$\underline{\text { Identificação do Trabalhador }}$

Nome:

Etnia (cor): Naturalidade: Nacionalidade:

Data de Nascimento: Estado Civil: $R G$ :

End. Res.: Tel:

Bairro: Cidade: CEP:

Em caso de emergência, avisar (grau de parentesco):

Nome: Tel:

\section{Aspectos Ocupacionais}

Profissão: Função:

Descreva resumidamente as suas atividades rotineiras no trabalho:

Aspectos da Saúde Geral

01.Atualmente está sob tratamento médico? ( ) Sim. Qual? ( ) Não Nome do Médico: Tel:

02.Está tomando algum medicamento? ( ) Sim. Qual(is)? ( ) Não 03.Passou por alguma cirurgia nos últimos 05 anos? ( ) Sim. Qual? ( ) Não 04. Já recebeu transfusão de sangue alguma vez? ( ) Sim. Motivo ( ) Não 05.Tem alergias a medicamentos (exemplo: penicilina), anestésico, material de limpeza ou outros? ( ) Sim. Quais: ( ) Não 
06.Qual(is) deste(s) sintoma(s) ou doença(s) você tem, ou já teve?
( ) Pressão Alta ( ) Pressão Baixa ( ) Hepatite
( ) Herpes
( ) Convulsões
( ) Desmaios
( ) Náuseas
( ) Sinusite
( ) Hemorragias
( ) Hemofilia
( ) Gastrite
( ) Nefrite
( ) HIV-positivo
( ) Diabetes
( ) Dist. Hepáticos
( ) Trat. Psiquiátrico ( ) Problemas cardíacos. Em que consiste?
07.Possui algum hábito ou vício (fuma tabaco, álcool ou drogas)? ( ) Sim （ ) Não
08.Quando se corta sangra muito? Demora a cicatrização? ( ) Sim
( ) Não
09.Se mulher, está grávida? ( ) Sim. Quantos meses?
( ) Não
10.Se mulher, toma anticoncepcional? ( ) Sim. Qual?
( ) Não

\section{Aspectos da Saúde Bucal}

11.Já recebeu orientação de higiene oral e técnica de escovação? ( ) Sim （ ) Não

12.Quando escova os dentes nota sangramento? ( ) Sim

( ) Não

13.Sente gosto desagradável na boca ou hálito cetônico? ( ) Sim

( ) Não

14.Tem o hábito de escovar os dentes? ( ) Sim Quantas vezes ao dia?

( ) Não

15.Faz uso de fio dental? Com que freqüência? ( ) Sim

( ) Não

16.Costuma fazer bochechos? ( ) Sim. Quando?

( ) Não

17.Já notou alguma mobilidade em seus dentes? ( ) Sim

( ) Não

18.Seus dentes são sensíveis à mudança de temperatura? ( ) Sim

( ) Não

19.Você mastiga de um lado só? ( ) Sim

( ) Não

20.Escuta algum ruído quando abre a boca ou mastiga? ( ) Sim

( ) Não

21.Você tem o hábito de ranger ou apertar os dentes? ( ) Sim

( ) Não

22.Você tem o hábito de morder o lábio ou objetos, roer unha? ( ) Sim

( ) Não

23. Você tem dificuldade de abrir a boca? ( ) Sim

( ) Não

24. Você tem dores nos músculos da face e/ou região dos ouvidos?( ) Sim ( ) Não 25.Você sente dores de cabeça freqüentes? ( ) Sim. Qual(is) analgésicos costuma tomar?

( ) Não

26.Usa algum tipo de prótese? ( ) Sim. Qual? quando foi

feita?

( ) Não

Certifico que as informações prestadas são exatas:

São Paulo, de de 20

Número funcional:

Assinatura do paciente: 
Ficha Admissional Odontológica

(preenchida pelo profissional)

Dia

Nome:

№ funcional:

Ocupação:

Profissão:

Considerações da anamnese:

\section{\# Condicões Dentárias}

(a) $\square \square \square \square \square \square \square \square \square \square \square \square \square \square \square \square$

(b) If

(c)

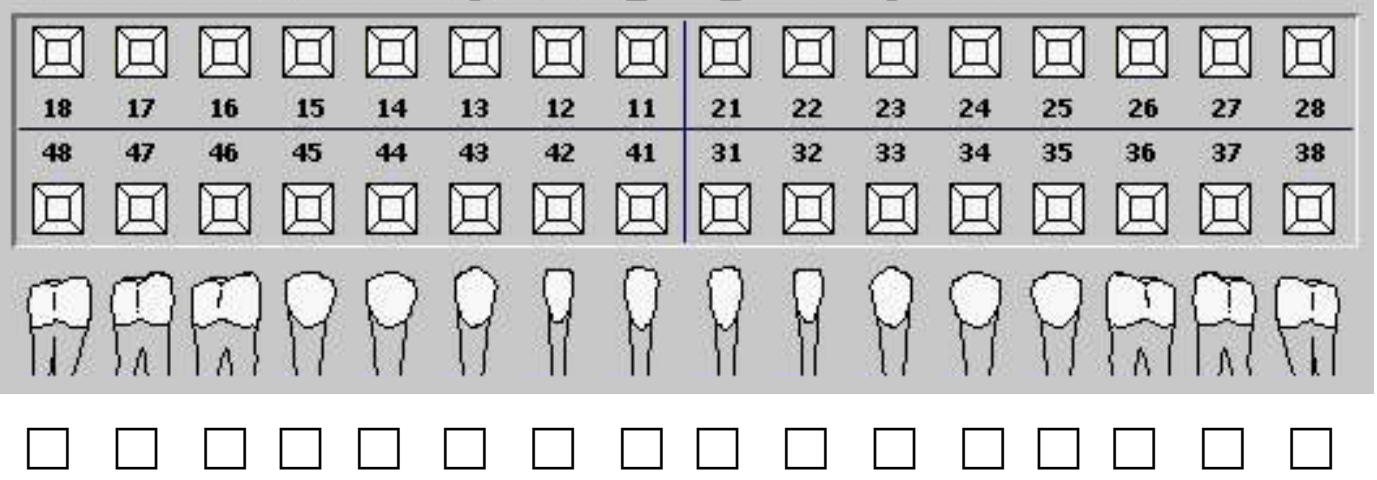

\section{CÓDIGO PARA PREENCHIMENTO DO ODONTOGRAMA}

\section{*Espaço (a)}

- Condição atual: H (Hígido) C (Cariado) RFI (Rest. Fraturada/Infiltrada) DF (Dente Fraturado)

- Material presente: Am (Amalgama) RF (resina Fotopolimerizável) Au (ouro) PP (Porcelana Pura) MC

(Metalocerâmica) MP (Metaloplástica) VN (Veneer) Nu (Núcleo Metálico) Pr (Provisório) IM (Implante)

* Espaço (b) - Tratamento Endodôntico / Exodontia (ausência) / Anodontia (ausência) / Extranumerários /

Próteses Fixas

* Espaço (c) - Faces Restauradas ou Comprometidas

\section{\# Condições dos Tecidos Peri-orais}

Intra-Oral: (assinalar na presença de alterações)

Lábio Superior $\square$ Lábio Inferior $\square$ Fundo de Sulco $\square$ Rebordo Alveolar $\square$

Mucosa Jugal $\square$ Palato Mole $\square$ Palato Duro $\square$ Língua $\square$

Assoalho de Língua $\square$ Glândula Salivar Maior $\square$ Glândula Salivar Menor $\square$

Extra-Oral: (assinalar na presença de alterações) 


\section{Atestado de Saúde Bucal Ocupacional (ASBO)}

Departamento:

Setor:

Em cumprimento a legislação interna vigente, atesto que o (a) trabalhador (a):

Nome: anos,

RG: Função:

Com exposição aos riscos ocupacionais:

\begin{tabular}{ll} 
( ) Riscos Físicos ( ) Riscos Biológicos ( ) Riscos Químicos \\
\hline
\end{tabular}

( ) Riscos Ergonômicos ( ) Sem Riscos Específicos

Riscos:

Foi submetido a Exame Odontológico:

( ) Admissional ( ) Periódico ( ) Mudança de Função ( ) Demissional

( ) Retorno ao Trabalho após:

( ) Acidente de trabalho ( ) Doença Ocupacional ( ) Doença/Acidente não ocupacional

( ) Parto

Exames Complementares solicitados:

realizados em:

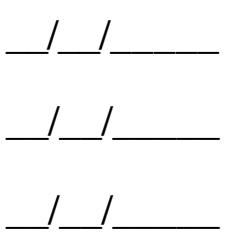

Orientações e Observações:

( ) Uso EPI ( ) Protetor Auricular ( ) Exercícios e Pausas ( ) Orient. Ergonômica ( ) Outra

Cirurgião Dentista Coordenador PSBT Exame Odontológico realizador por:

Dr. $\mathrm{CRO}($ tel:

Carimbo/Assinatura/endereço do $C D$ examinador

Realizei o exame odontológico acima e recebi cópia do presente Atestado (ASBO) em -1_ 


\section{PARECER $\mathbf{n}^{\circ}$}

\section{Protocolo XX/02}

O Grupo de Trabalho indicado pelo Comitê de Ética em Pesquisa APROVOU o protocolo de pesquisa "Avaliação da Atuação dos Serviços Odontológicos sobre Saúde do Trabalhador nas Empresas", de responsabilidade do pesquisador Ísis Ryal Crosato, sob a orientação da Professora Moacyr da Silva.

Tendo em vista a legislação vigente, devem ser encaminhados a este Comitê relatórios referentes ao andamento da pesquisa em (alterar)04 de janeiro de 2003 e em 04 de julho de 2003. Ao término da pesquisa, cópia do trabalho deve ser encaminhada a este CEP.

São Paulo, 04 de julho de 2002

Coordenador(a) do CEP-FOUSP 